\title{
ESTUDO COMPARATIVO DE CINCO CULTIVARES E DOIS TIPOS DE FERTILIZANTE EM CULTURA DE MILHO ( $\mathscr{Z}_{\text {ea mays }}$ L.).
}

\author{
JAIRO AUGUSTO CAMPOS DE ARAUJO
}

Orientador: Prof. Dr. ANTONIO SANCHEZ DE OLIVEIRA

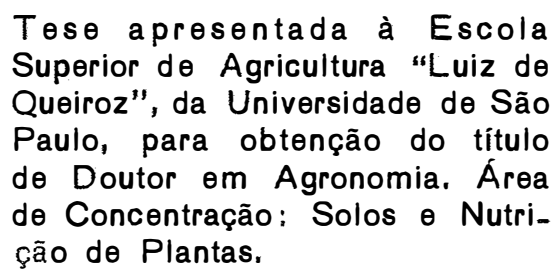

PIRACICABA

Estado de São Paulo - Brasil

Novembro, 1985 
.ii.

Aos

meus pais, pela confiança demonstrada

$$
\text { o e d i c o }
$$

A Samira M.C. de Araujo

Cesar Augusto e João Paulo, pela demonstração de carinho $e$ compreensão.

$$
\text { o f e reso }
$$


. iii.

H O MENAGENS ESPECIAIS

Ao Eng? Agr: RUBENS RUSSO, pela orientação e a poio no início de nossa carreira como Engenheiro Agrônomo.

Ao Prof. Dr. LUIZ ROBERTO LOPES, na qualidade de orientador departamental, pelo convívio e experiências trans mitidas desde o início de nossas atividades no campo universi tário. 


\section{A G R A DE C I MENTOS}

- Ao Prof. Dr. Antonio Sanchez de Oliveira, pela orientação, dedicação e colaboração oferecidas na execução deste tra balho;

- Aos Professores do Departamento de Engenharia Rural da Fa culdade de Ciências Agrárias e Veterinárias, Campus de Ja boticabal - UNESP, pela demonstração de estímulo e confian ça;

- Ao Departamento de Biologia Aplicada à Agropécuária da Fạ culdade de Ciências Agrárias e Veterinárias, Campus de Ja boticabal-UNESP, em especial aos Profs. Drs. Juan Ayala Osuna e Samira Miguel Campos de Araujo pelas sugestões oferecidas na realização deste trabalho, assim como, a Profa. Dra. Terezinha de Jesus Déleo Rodrigues pela confec ção do summary.

- Ao Departamento de Solos e Adubos da Faculdade de Ciências Agrārias e Veterinárias, Campus de Jaboticabal - UNESP, em particular aos Profs. Drs. Godofredo Cesar Vitti e Edson Luiz Mendes Coutinho vela colaboração e participação na ins talação deste trabalho; 
- Ao Departamento de Ciências Exatas da Faculdade de Ciências Agrárias e Veterinárias, Campus de Jaboticabal - UNESP, em especial ao Prof. Dr. David Ariovaldo Banzatto pela colabo ração nos programas estatísticos, assim como as sugestões oferecidas na redação deste trabalho;

- Ao Prof. Dr. Paulo Afonso Berlingieri do Departamento de Tecnologia da Faculdade de Ciências Agrárias e Veterinā rias, Campus de Jaboticabal - UNESP, pela colaboração na análise qualitativa dos diversos materiais de milho;

- A Coordenação de Aperfeiçoamento de Pessoal de Nível Supẹ riox do Ministério da Educação e Cultura, convênio PICDCAPES/UNESP, na pessoa do Prof. Dr. Rubens Sader, coordena dor da CCD/FCAVJ, pelas condições oferecidas.

- Ao Departamento de Economia Rural, da Faculdade de Ciências Agrárias e Veterinārias, Campus de Jaboticabal - UNESP, em particular ao Prof. Dr. Argemiro Oliveira Sousa pelas su gestões oferecidas na revisão deste trabalho.

- A Regina Célia pelos serviços de datilografia.

- A Bibliotecária Núbia Josefina Lopes pela revisão na litẹ ratura. 
- Aos funcionários dos Departamentos de Engenharia Rural e Biologia Aplicada a Agropecuária da Faculdade de Ciências Agrärias e Veterinārias, Campus de Jaboticabal - UNESP, pe la ajuda constante.

- A Direção da Faculdade de Ciências Agrárias e Veterinārias de Jaboticabal-UNESP, assim como, a Díreção da Escola Supe rior de Agricultura "Luiz de Queiróz" - USP, pelas oportü nidades oferecidas.

- Aos Profs. Drs. Mário Benincasa, Geraldo Victorino de França, Decio Eugenio Cruciani e Antonio F.L. Olitta, membros da banca examinadora, pelas sugestões oferecidas.

- A todos que colaboraram para a realização deste trabalho recebam o nosso muito

Obrigado. 
Pāgina

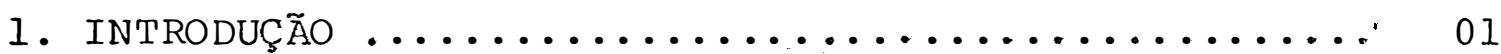

2. REVIS $\tilde{O} O$ DE LITERATURA..................... 04

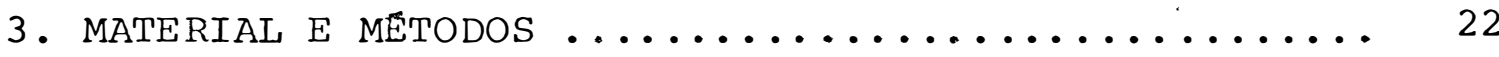

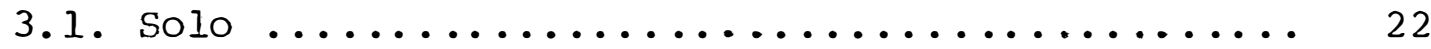

3.2. Sementes, Semeadura e Desbastes ........... 23

3.3. Delineamento Experimental e Tratamento....... 25

3.4. Observações Climatolögicas............... 29

3.5. Anālise do Desenvolvimento da Cultura ....... 29

3.5.1. Altura das Plantas .................. 29

3.5.2. Nümero de Folhas ............... 30

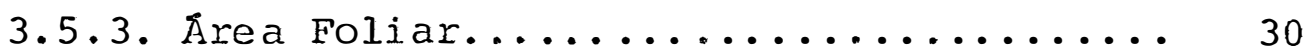

3.5.4. Acumulação de Matéria Seca.......... 30

3.5 .4 .1$. Colmo $\ldots \ldots \ldots \ldots \ldots \ldots \ldots \ldots \ldots$

3.5 .4 .2$. Bainha.................... 31

3.5.4.3. Làminas Foliares .......... 31

3.5.4.4. Inflorescência Masculina..... 32

3.5.4.5. Inflorescência Feminina...... 32 
viii.

Păgina

3.5.4.6. Acumulação da Matēria Seca Tó tal $\ldots \ldots \ldots \ldots \ldots \ldots \ldots \ldots \ldots \ldots$

3.5.5. Diagnose Foliar ............. 33

3.5.6. Análises Químicas das Folhas ........ 33

3.6. Avaliação da Produção $\ldots \ldots \ldots \ldots \ldots \ldots \ldots \ldots . . \ldots \ldots$

3.6.I. Comprimento das Espigas .......... 34

3.6.2. Circunferência das Espigas ........ 34

3.6.3. Nümero de Fileiras de Grãos por Espi ga $\ldots \ldots \ldots \ldots \ldots \ldots \ldots \ldots \ldots \ldots \ldots \ldots \ldots \ldots$

3.6.4. Número de Grãos por Fileira ....... 34.

3.6.5. Peso da Espiga Principal ......... 34

3.6.6. Peso de Quinhentos Grãos.......... 35

3.7. Anālise Qualitativa da Produção .......... 35

3.7.1. Proteína Total dos Grãos .......... 35

4. RESULTADOS E DISCUSSÕES................. 36

4.1. Observações Climatológicas............. 36

4.2. Altura das Plantas ................. 38

4.3. Número de Folhas ................. 41

4.4. Ârea Foliar ........................ 44

4.5. Comprimento do Colmo .............. 48

4.6. Acumulação da Matéria Seca ............. 50 
ix.

Página

4.6.1. Colmo .................... 50

4.6.2. Bainha ..................... 53

4.6.3. Lâminas Foliares ............... 57

4.6.4. Inflorescência Masculina .......... 61

4.6.5. Inflorescência Feminina .......... 63

4.6.6. Acumulação de Matéria Seca Total ..... 63

4.7. Análise Química das Folhas ...............6 67

4.7.1. Macronutrientes ............... 68

4.7.2. Micronutrientes $\ldots \ldots \ldots \ldots \ldots \ldots \ldots, 76$

4.8. Avaliação da Produção.................. 81

4.8.1. Comprimento das Espigas .......... 81

4.8.2. Circunferência das Espigas ........ 84

4.8.3. Número de Fileiras de Graõs por Espí

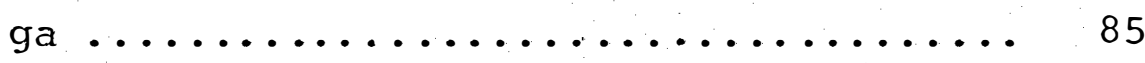

4.8.4. Nümero de Grãos por Fileira ........ 86

4.8.5. Peso da Espiga Principal .......... 87

4.8.6. Peso de Quinhentos Grãos ............ 87

4.9. Análise Qualitativa da Produção ........... 88 4.9.1. Proteína Total dos Grãos ............ 88

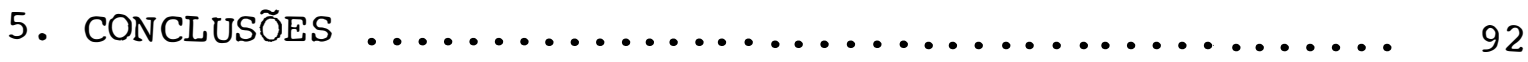

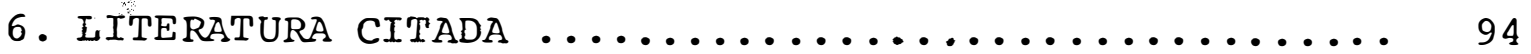

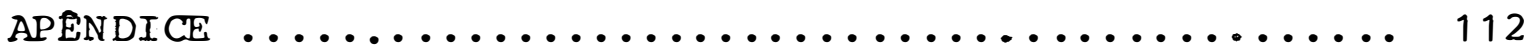




\section{LISTA DE QUADROS}

Pägina

1 Resultados da Análise Química da Camada Su-

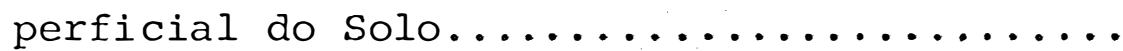

2 Composição do Efluente de Biodigestor Utilizado $\ldots \ldots \ldots \ldots \ldots \ldots \ldots \ldots \ldots \ldots$

3 Valores de $F$, coeficientes de variação, mé dias dos materiais e médias dos adubos, para os dados de altura das plantas (cm), nas di versas amostragens $\ldots \ldots \ldots \ldots \ldots \ldots \ldots \ldots$

4 Valores de F, coeficientes de variação, mé dias dos materiais e médias dos adubos, pa ra os dados de número de folhas, nas diver sas amostragens $\ldots \ldots \ldots \ldots \ldots \ldots \ldots \ldots \ldots$ 
.xi.

Quadro

Păgina

5 Valores de $F$, coeficientes de variação, mé dia dos materiais e médias dos adubos, para os dados de área foliar $\left(\mathrm{dm}^{2}\right)$, nas diversas amostragens $\ldots \ldots \ldots \ldots \ldots \ldots \ldots \ldots \ldots$

6 Valores de $\mathrm{F}$ para o desdobramento dos graus de liberdade da interação adubos $x$ materiais (A $\times$ M) e médias dos materiais dentro de ca da fertilizante, para área foliar $\left(\mathrm{dm}^{2}\right)$, aos

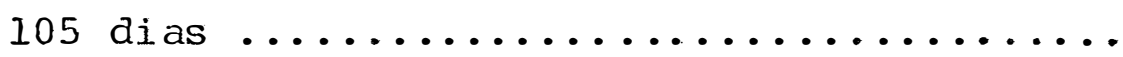

7 Valores de F, coeficientes de variação, mé dias dos materiais e médias dos adubos, para os dados de comprimento dos colmos (cm), nas

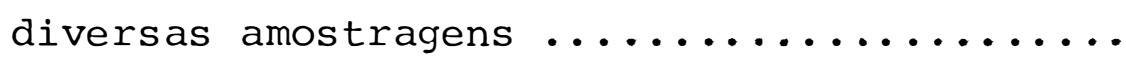

8 Valores de $F$, coeficientes de variação., mê dias dos materiais e médias dos adubos, para os dados de produção de matéria seca acumula da nos colmos (g), nas diversas amostragens. 
.xi广

Quadro

Pāgina

9. Valores de $F$, coeficientes de variação, mé dias dos materiais e médias dos adubos, para os dados de produção de matéria seca acumu lada nas bainhas (g), nas diversas amostra gens $\ldots \ldots \ldots \ldots \ldots \ldots \ldots \ldots \ldots \ldots \ldots \ldots \ldots \ldots \ldots \ldots \ldots \ldots \ldots$

10 Valores de $F$ para o desdobramento dos graus de liberdade da interação adubos $\mathrm{x}$ materiais (A x M) médias dos materiais dentro de cada fertilizante, para a produção de matéria se ca acumulada nas bainhas $(\mathrm{g})$, aos 60 dias...

11 Valores de F, coeficientes de variação, mé dias dos materiais e médias dos adubos, para os dados de produção da matéria seca acumu lada nas folhas ( $\mathrm{g})$, nas diversas: amostra

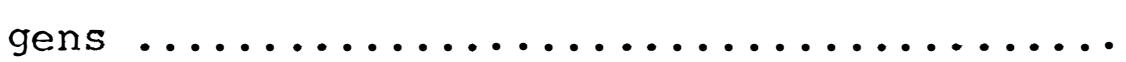

12 Valores de $\mathrm{F}$ para o desdobramento dos graus de liberdade da interação aduoos $\mathrm{x}$ materiais (A $\times$ M) e médias dos materiais dentro de ca da fertilizante, para a produção de matéria seca acumulada nas folhas (g), aos 105 dias. 
13 Valores de $F$, coeficientes de variação, mé dias dos materiais e médias dos adubos, para os dados da produção da matéria seca acumü lada nos pendões (g), nas diversas amostra gens $\ldots \ldots \ldots \ldots \ldots \ldots \ldots \ldots \ldots \ldots \ldots \ldots \ldots \ldots \ldots \ldots \ldots \ldots \ldots$

14 Valores de $F$, coeficientes de variação, mē dias dos materiais e médias dos adubos para os dados da produção da matéria seca acumu lada nas espigas (g), nas diversas amostra gens $\ldots \ldots \ldots \ldots \ldots \ldots \ldots \ldots \ldots \ldots \ldots \ldots \ldots \ldots \ldots \ldots \ldots \ldots \ldots$

15 Valores de $F$, coeficientes de variação, mé dias dos materiais e médias dos adubos, para os dados de peso de matéria seca (g/planta) acumulado nas diversas amostragens............

16 Teores mínimos adequados (Niveis Criticos) dos macronutrientes para a cultura do milho cultivada em São Paulo (TRANI et alii, 1983). 
.xiv.

Quadro

Pāgina

17 Valores de $F$, coeficientes de variação, mé dias dos materiais e médias dos adubos para os teores médios dos macronutrientes (\%) pre

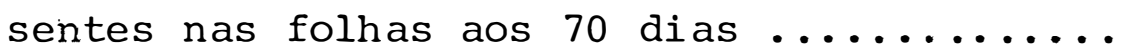

18 Valores de $\mathrm{F}$ para o desdobramento dos graus de liberdade da interação adubos $\mathrm{x}$ materiais (A X M) e médias dos materiais dentro de ca da fertilizante, para os macronutrientes $\mathrm{P}$ e

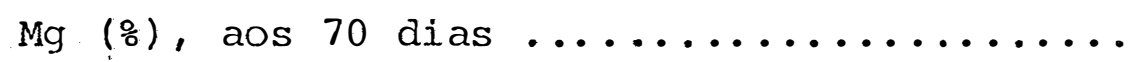

19 - Comparação dos teores de macronutrientes em \%, presentes nas folhas, aos 70 dias após a semeadura, com os teores mínimos adequados propostos por TRANI et alii (1983), para a cultura ào milho cultivada no Estado de são Paulo..........................

20 Valores de F, coeficientes de variação, mé dias dos materiais e médias dos adubos, para os teores médios dos micronutrientes ( ppm) presentes nas folhas aos 70 dias .......... 
.$x V$.

Quadro

21 Valores de $\mathrm{F}$ para o desdobramento dos graus de liberdade da interação adubos $\mathrm{x}$ materiais (A $\times$ M) e médias dos materiais dentro de ca da fertilizante para os micronutrientes Fe,

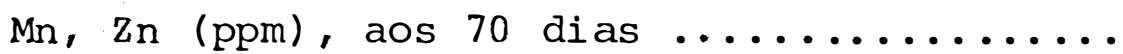

22 Valores de F, coeficientes de variação, mé dias dos materiais e médias dos adubos: mine ral e orgânico, para os dados da produção em suas vārias expressões, na amostragem reali zada aos 150 dias após a semeadura........

23 Valores de F para o desdobramento dos graus de liberdade da interação adubos $x$ materiais ( $\mathrm{A} \times \mathrm{M})$ e médias dos materiais dentro de ca da fertilizante para os dados de comprimento

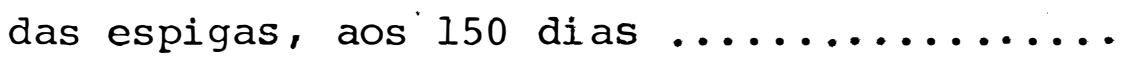

24 Valores de $F$, coeficientes de variação, mé dias dos materiais e médias dos ađubos para os dados de teor de proteína (\%) dos grãos.. 
25 Comportamento dos diversos cultivares de mi

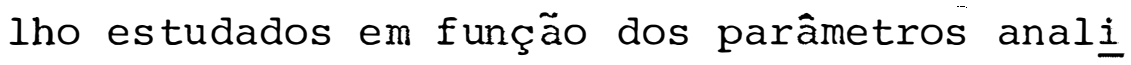
sados, valores de F para a causa de variação Adubos e médias dos tipos de fertilizante utilizados $\ldots \ldots \ldots \ldots \ldots \ldots \ldots \ldots \ldots \ldots \ldots \ldots \ldots$ 
.xvii.

\section{LISTA DE FIGURAS}

Figura

Pägina

1. Esquema geral de distribuição dos tratamen tos e dos blocos experimentais...........

2. Detalhe de uma parcela experimental........

3. Valores de precipitação pluviométrica corres pondente ao período de novembro de 1984 a

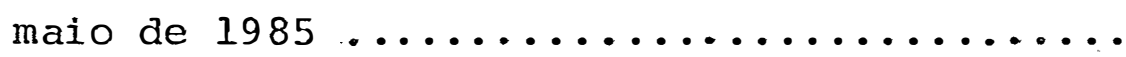


ESTUDO COMPARATIVO DE CINCO CULTIVARES E DOIS TIPOS

DE FERTILIZANTE EM CULTURA DE MIIHO (Zea mays L.)

\author{
JAIRO AUGUSTO CAMPOS DE ARAUJO \\ - Autor - \\ Prof. Dr. ANTONIO SANCHEZ DE OIIVEIRA \\ - Orientador -
}

RESUMO

A presente pesquisa desenvolveu-se no municipio de Jaboticabal - SP, em uma área experimental da Faculdade de Ciências Agrárias e Veterinárias - UNESP, no ano agrícola $84 /$ 85, num solo classificaäo como Latossol Vermelho Escuro - "fase arenosa" (COMISSÃO DE SOLOS, 1960), série Santa Teresa, segundo ALOISI e DEMATTE (1974).

Foram utilizados cinco cultivares de milho, assim definidos: Piranão, Híbrido Duplo (7974), Composto Filint, Composto Dentado e Híbrido Dina 10 .

Como fonte de adubo orgânico, foi utilizado o efluente de biodigestor, resultante da fermentação anaeróbica de estrume bovino diluído em água.

o objetivo da presente pesquisa foi o de ava- 
liar o comportamento de diversos cultivares de milho, através da utilização de variedade, hỉbridos e compostos, com o uso de adubação mineral e adubação orgânica como fonte de nutrientes para a cultura, adotando-se quantidades idênticas de nitrogênio (60 kg/ha de $N$ ) para as duas formas de adubação.

Com relação ao desenvolvimento da cultura analisaram-se a sua altura, o número de folhas, o comprimento do colmo, a área foliar, a acumulação de matéria seca nos diversos órgãos da planta (colmo, lâmina foliar, inflorescência mas culina e inflorescência femininal e a acumulação de matéria se ca total. Foram efetuadas ainda, análises quimicas das folhas. Avaliaram-se as seguintes caracteristicas: comprimento e circunferência das espigas, o número de fileiras de grãos por espiga, o número de grãos por fileira, o peso da espiga principal e o peso de quinhentos grãos.

Analisou-se também a qualidade do produto colhido, através da determinação do teor de proteína total dos grãos.

A partir dos resultados obtidos pode-se inferir que:

a) De modo geral, as diferenças observadas no comportamento das plantas de cada tipo de milho, com relação aos tipos de fertilizantes utilizados, não foram significativas;

b) Com relação à produção, avaliaảa através do 
peso da espiga principal, observa-se que o Híbriảo Dina 10 a presenta os maiores valores médios quando comparaảos com os dẹ mais cultivares de milho;

c) Com base no teor de proteína total dos grãos, observa-se que a melhor resposta foi apresentada pelo Composto Flint. 
.$x x i$

COMPARATIVE STUDY OF FIVE CULTIVARS AND TWO TYPES OF FERTILIZER IN CORN (Zea mays L.) CROP

JAIRO AUGUSTO CAMPOS DE ARAUJO

- Author -

Prof. Dr. ANTONIO SANCHEZ DE OLIVEIRA

- Adviser -

SUMMARY

This research was conducted in Jaboticabal - SP, Faculdade de Ciências Agrárias e Veterinárias - UNESP, during the crop season of $84 / 85$. The soil of the experimental area is classified as Latossol Vermelho Escuro - "fase arenosa série Santa Teresa", according to ALOISI e DEMATTE (1974). The objective of this research was to evaluate the behavior of several corn cultivars, through the utilization of variety, hybrids and composites, and using mineral fertilization and organic fertilization as the nutrient source for the crop, but adopting, identical amounts of Nitrogen $(60 \mathrm{~kg} \mathrm{~N} / \mathrm{ha})$ for both types of fertilization. Five corn cultivars were used and they were 
defined as: Piranão, Hîbrido Duplo (7974), Composto Flint, Composto Dentado and Híbrido Dina 10.

The source of organic fertilizer was a biodigestor efluent, which resulted from the anaerobic fermentation of cattle manure diluted in water.

The following parameters related with the crop development were analysed: plant height, number of leaves, stalk length, leaf area, dry matter accumulation in the various plant organs (stalk, leaf sheath, leab blade, male inflorescence and female inflorescence), and total dry matter accumulation.

The following measurements: length and circunference of the ears, the number of rows of grains per ear, the grains number per row, the weight of the main ear, and the weight of five hundred kernels.

The quality of the harvested product was evaluated through the determination of the levels of total protein of the grains.

The results obtained allow the following conclusions:

a) In general, the observed differences, related with the utilized fertilizers were rot significant;

b) Híbrido Dina 10 presented higher mean values of main ear weight when compared with the other cultivars used.

c) It was observed that Composto Flint presented higher levels of total protein of the grain. 
1. INTRODUÇ̃̃O

O crescimento demográfico que apresenta a raça humana, em termos mundiais, oferece-nos um desafio constante para a apresentação de propostas de trabalho que objetivem pro piciar a todos os povos condições mínimas satisfatórias para o seu perfeito desenvolvimento.

O progresso científico da agricultura, de uma ma neira geral, teve início a partir do ano de 1840, com trabalhos desenvolvidos por Lewes e Gilbert, por Mendel e Mac Cormick, respectivamente, nas áreas de solos e adubo, da genética e dä mecanização agrícola.

、 Os precursores da aplicação dos fertilizantes químicos foram Lewes e Gilbert, que através da Estação Experí mental da Rothamsted na Inglaterra, a partir de 1843, deram início ao estudo científico dos solos e da nutrição das plan tas. Desta forma, iniciou-se a contestação das teorias desen 
volvidas por von Liebig que acreditava ser o ar a única fonte de nitrogênio, mediante a aplicação de esterco a canteiros de trigo, onde a agricultura obedecia o processo fechado, em que o esterco representava exclusivo meio de fertilização.

Talvez, devido à necessidade imediata de respos ta das plantas, em termos de maior produção, para atender a demanda sempre crescente de alimentos tenham Lewes e Gilbert contribuído para fortalecer o uso da adubação mineral na alimentação das plantas, visto que seus efeitos favoráveis sobre a produtividade e, aparentemente, sobre a fertilidade são notá veis.

O uso isolado e indiscriminado dos sais minerais vem criando sérios problemas na América Latina, por exemplo, na Argentina, onde regiões outrora tritícolas, hoje estão com pletamente estéreis. Os solos brasileiros, certamente, estão sujeitos aos mesmos males, visto que a nossa agricultura con tinua, de certa forma, a ser praticada em caráter predatório.

Dentro do objetivo primordial de produzir ali mentos para uma população cada vez maior no globo terrestre , associada ao desafio imposto pela crise econômica, principal mente aos países em desenvolvimento, buscam-se meios alterna tivos de conciliar boas produções, com menores custos e com menor alteração possível ao equilíbrio ecológico.

Vários pesquisadores. dentro desta filosofia, vol taram sua atenção para o estudo de diferentes tipos de adụ 
bos orgânicos e para os resultados obtidos pela sua aplica ção em parcelas experimentais. RUSSEL (1976) afirma que "de ve-se admitir que ao se trazer esterco para o campo, alguma coisa que havia sido retirada está sendo devolvida ao solo".

Para suprir a demanda energética das proprieda dades agrícolas, cada vez mais se intensifica o emprego de biodigestores anaeróbicos, com 0 uso de diferentes substratos, principalmente o estrume de bovinos, suínos e aves, onde par te da energia gerada é consumida através do acionamento de mo tores, para os mais diversos fins, na forma de gás para aque cimento, iluminação, cozimento, etc.; e outra parte, o subs trato, após sofrer a fermentação anaeróbica é liberado na for ma líquida, podendo ser aplicado ao solo com o uso de máquinas espalhadoras de adubos líquidos.

As pesquisas, em que se utilizam efluente de bio digestor como forma de adubação orgânica, se intensificam mas ainda pouco se conhece sobre as interrelações desta prática no sistema solo-planta.

O objetivo da presente pesquisa foi o de anali sar o comportamento de diversos materiais de milho, através da utilização de variedade, híbridos e compostos, quando se usa de adubação mineral e adubação orgânica como fonte de nutrien tes para a cultura, adotando-se quantidade idêntica de nitro gênio por hectare para as duas fontes de adubação. 


\section{REVISÃO DE LITERATURA}

Desde há muito, GREGORY \& CROWTHER (1928) apon taram que há possibilidade de se tirar partido das diferen ças genéticas entre as plantas, procurando adequá-las ao am biente, com prováveis ganhos na produção, sem alterações mui tas vezes dispendiosas nas prāticas de cultivo.

Alguns estudiosos como GERLOFF (1963), EPSTEIN \& JEFFERIES (1964), SPRAGUE (1969) e EPSTEIN (1972) apresentaram citações sobre a influência do germoplasma na absorção, trans locação e utilização de nutrientes nas plantas.

o estudo do crescimento e desenvolvimento vege tal, de acordo com MEYER et alii (1960), deve abordar as carac terísticas fisiológicas e morfológicas de cada tipo de planta, podendo ser reconhecido como expansão em tamanho associada com certas modificações fisiológicas, enquanto que os aumentos em peso acham-se associados às características que são quase o in 
verso daquelas do crescimento, tais como: acúmulo de substân cias de reserva nos tecidos especiais, condensação de substân cias simples formando substâncias mais complexas, etc.

A altura da planta é função do comprimento do internódio, como também do seu número, porém ANDERSON \& CHOW (1963) em seus estudos com vários cultivares de milho não en contraram diferenças para o número total de internódios entre plantas normais e as de porte baixo. Por outro lado, SCOTT \& CAMPBELL (1969) mencionaram a ocorrência da redução do nūmero de internōdios nas plantas de porte baixo em relação àquelas normais.

Muitos pesquisadores têm reportado significância nas relações existentes entre número de folhas e maturidade em milho como CHASE \& NANDA (1966); CHASE \& NANDA (1967); DUNCAN \& HESKETH (1968); ALLEN et alii (1973); e CROSS \& ZUBER (1973), os quais ressaltaram que o número de folhas por plantas cons titui um índice da idade fisiológica do florescimento.

O número de folhas em milho é um atributo que dí fere com o genótipo, conforme observaram HESKETH et alii(1969), os quais assinalaram também que mudanças no nível de nutrien tes não alteraram o número de folhas, porém esta característi ca acha-se correlacionada com o peso da matéria seca e com a ārea foliar.

ANDERSON \& CHOW (1963) e SING \& CRAI(1979) estu daram plantas de milho de porte normal e plantas de porte bai xo e não constataram nenhuma diferença entre as plantas quanto 
ao número de folhas. Por outro lado, POEY (1973) observou que nas plantas de milho contendo o gene braquítico, este deter mina um aumento na largura das folhas.

Analisando o número de folhas e o período de florescimento, CHASE \& NANDA (1967) e ROOD \& MAJOR (1981) rela taram a ocorrência de uma correlação muito estreita entre es tes caracteres, isto é, selecionando-se plantas visando a pre cocidade, tem-se uma diminuição no número de folhas, contra riando ANDERSON \& CHOW (1963), os quais não encontraram nenhu ma diferença entre plantas altas e baixas, quianto ao nūmero de folhas. Por outro lado, SCHMIDT \& COLVILLE (1967) verifica ram que as folhas localizadas acima ou abaixo da espiga de mi lho foram igualmente eficientes para produção de grãos.

Segundo HESKETH et alii (1969), o nūmero de fo lhas acha-se correlacionado com o peso da matéria seca e com a área foliar, nos híbridos de milho estudados.

$$
\text { Segundo WATSON (1952), a área foliar tem sido }
$$

reconhecida como um importante determinante da produção bioló gica.

O Indice de área foliar, o qual é uma relação en tre a área de folha da cultura e a área de solo por ela ocupa da, é um Indice de grande importância, pois indica a àrea das folhas que em um determinado momento pode estar interceptando a luz solar, em relação ao espaço por ela ocupado, este índice varia com o genótipo e com as condições ambientais. Conforme observou TOLLENAAR (1977), o Índice de ārea foliar no início 
do desenvolvimento das plantas é baixo; na fase inicial de crescimento na cultura do milho não há competição por luz en tre as plantas, pois todas as folhas recebem luz e o índice de área foliar é limitante à produção de matéria seca. Acrescenta ainda, que no período de florescimento é que o índice de área foliar é máximo, passando a declinar no período de enchimento de grão.

Conforme ressaltaram TANAKA \& YAMAGUCHI (1972), O processo de crescimento da planta de milho compreende quatro fases distintas, ou seja: a) fase vegetativa inicial na qual a produção de matéria seca é pequena e as folhas estão sendo formadas; b) fase vegetativa ativa na qual se acham em desen volvimento folhas, colmos e primórdios dos órgãos reproduti vos, havendo inicialmente um aumento ativo no peso das folhas e depois do colmo; esta fase termina com o aparecimento. dos "cabelos" do milho; c) na fase inicial de enchimento dos grãos, há um contínuo aumento no peso das folhas e do colmo, porém em menor velocidade, enquanto as palhas e o sabugo continuam a ganhar peso, havendo inícịo de formação dos grãos; d) fase atí va de enchimento do grão, a qual se caracteriza por um ganho maior do peso dos grãos e um decréscimo do peso das folhas, colmo palhas e sabugo (raquis).

HANWAY (1962), es tudando a acumulação progressi va da matéria seca em plantas de milho, verificou que as va riações na fertilidade do solo produziram diferentes níveis de acumulação. Notou, no entanto, que as mesmas não influiram notoriamente nas proporções relativas das diferentes partes 
da planta. Além disso, verificou que o peso seco do colmo per maneceu relativamente constante, depois de atingido o seu pon to máximo, o que ocorreu alguns dias após a emissão da espiga. Estudando a acumulação do peso seco do colmo, HOYT \& BRADFIELD (1962) encontraram uma redução significativa, em diversos cultivares de milho, no final do ' amadurecimento dos grãos.

A relação entre a nutrição mineral e a produção de grãos é complexa, e de certo modo indireta. Conforme rela tou ASHBURN (1971), a sua ação deve ser efetiva pelo desenvol vimento de maior área foliar, ou então como citou HANWAY(1962), maior produção de matéria seca na planta toda, ou no aumento da taxa e tempo de enchimento dos grãos, conforme demonstraram PEASLEE et alii (1971). Além disso, ressaltou ASHBURN (1971) a uma maior disponibilidade de nutrientes permite uma maior po pulação efetiva, no campo.

Realizando estudos em plantas de milho, KOLLER (1972) observou que todas as partes da planta (folhas, colmo, e sabugo) perdem matéria-prima seca antes da maturação fisio lógica, fato este que se deve principalmente à translocação de glicídeos para os grãos.

A produção de matéria seca está intimamente re lacionada com o metabolismo nitrogenado, devido à necessida de de suprimento do nitrogênio para sua produção. De acordo com DARWINKELL (1975), a fotossíntese e a respiração têm im portância fundamental na produção de matéria seca, sendo es 
ses processos influenciados pela intensidade luminosa, nutrien tes, temperatura e água.

As variedades melhoradas de milho, selecionadas por CROSBIE \& MOCK (1981), foram superiores às respectivas orí ginais, quanto ao aumento no período de enchimento dos grãos, como ainda houve maior produção de matéria seca por planta.

Segundo GERLOFF (1963), o conteúdo de nutrien tes da planta pode indicar características comuns entre ambien tes particulares.

Alguns estudiosos, como BARBER et alii (1967) e BAKER et alii (1970) e BAKER et alii (1971) verificaram que o carāter genético, para maior acumulação de fósforo, não é ne cessariamente traduzido em maior produção de grãos. Assim as variedades que apresentam baixa acumulação devem fazer uma cer ta economia desse nutriente, através de uma maior taxa de con versão de nutrientes em grãos.

Por outro lado, B ROWN et alii (1972) constataram que as linhagens de milho ineficientes para a absorção de ferro apresentaram maiores concentrações de fosfato $\left(\mathrm{H}_{2} \mathrm{PO}_{4}^{-}\right)$, cobre $\left(\mathrm{Cu}^{++}\right)$e outros ions antagônicos ao $\mathrm{Fe}^{++}$.

* Estudos realizados com fósforo radioativo por RABIDEAU et alii (1950) em linhagens e híbridos de milho verí ficaram a ocorrência de correlação entre o volume de solo ex plorado pelas raízes e a capacidade de acumulação de nutrien tes dos germoplasmas. Conforme observou SNIDER (1953), é pro vável que o aumento da superfície ativa da raiz seja o princí 
pal fator para eficiência de absorção de fósforo, embora EP $\underline{S}$ TEIN (1972) tenha referido que deve haver aumento na absorção de todos os nutrientes. Ainda conforme referiram BAKER et alii (1970), hã uma enorme variabilidade na taxa de absorção de fosfato na área de exposição das raízes, a qual é genetica mente controlada. Assim BARBER et alii (1967) mostraram que em milho, pelo menos dois genes acham-se envolvidos no contro le da acumulação de fósforo, provavelmente com dominância para baixo teor. Por outro lado, BARBER \& THOMAS (1972) demonstra ram que a expressão dos genes relativos à acumulação de $P$ nas folhas pode ser grandemente afetada pelas propriedades do so 10 .

Tem sido demonstrado que sob o aspecto fisiolō gico, alguns compostos são importantes na acumulação diferen cial de $\mathrm{P}$ por variedade de milho. Conforme relataram PHILLIPS et alii (1971), o nível de ortofosfato é diferente; BAKER et alii (1971) verificaram que há maior síntese de proteínas que podem se ligar a este ion, e KLIMASHEVSKII (1966) verificou que as variedades de milho que mais respondem à adubação fos fatada aumentam a taxa de transporte de monossacarídeos para as raízes.

A acumulação de $P$, geneticamente controlada, não è afetada pela absorção de outros elementos como K, Ca, $\mathrm{Mg}, \mathrm{Mn}$, $\mathrm{Fe}, \mathrm{Cu}, \mathrm{B}, \mathrm{Al}, \mathrm{Sr}$ e $\mathrm{Zn}$, conforme relataram BARBER et alii (1967). Por outro lado, BAKER et alii (1971), trabalhando com populações selecionadas de milho para alto e baixo teor de 
fósforo nas folhas, verificaram que o aumento na absorção de $\mathrm{P}$ acarreta aumento significativo na concentração de $\mathrm{S}, \mathrm{Ca}, \mathrm{Cu}$ e B nas plântulas, enquanto que nas folhas pode estar associa do a uma maior concentração de $\mathrm{N}$, e menor de $\mathrm{Fe}, \mathrm{Al}$ e possi velmente Mn.

Conforme observou NEPTUNE (1966), o modo e época de aplicação do nitrogênio têm influência na marcha de absor ção deste nutriente, na acumulação de matéria seca nas partes vegetativas e principalmente nos grãos. Relatou também que a aplicação tardia deste nutriente aumenta o tempo de enchimento do grão, e, provavelmente diminui a área foliar, dando uma menor taxa de acumulação relativa.

Por outro lado, tem sido demonstrado por vários autores que rendimentos de grãos e percentagem de proteína dos grãos em plantas cultivadas não apresentam correlação lí near, conforme apontaram ALEXANDER et alii (1969) em seus es tudos com milho; LOFFER \& BUSCH (1982), com trigo e CARTER et alii (1982), com soja.

O nitrogênio é essencial para aumentar a produ ção de grãos de milho (Zea mays L.); recentes estudos desen, volvidos por Lee (1981) e citados por TSAI et alii (1984) indi. cam que altos níveis de fertilizante nitrogenado prolongam e aumentari a taxa de enchimento do grão, quando comparados com bai xo suprimento de nitrogênio.

Estudos realizados por TSAI et alii (1980)

e

(1983) têm demonstrado que o movimento dos açúcares e a acumu 
lação da matéria seca dos grãos acham-se regulados pela disposição de componentes nitrogenados no grão, como a proteína zeĩna.

Procurando analisar o teor de nitrogênio nas se mentes de milho, ANDERSON et alii (1982) constataram que hou ve aumento neste teor, proporcional ao aumento da dose de fer tilizante nitrogenado aplicado ao solo, antes do plantio.

Foi demonstrado por MC NEAL et alii (1971) que a adubação nitrogenada em trigo tem influência direta na percentagem de proteína do grão, isto é, alto teor de $\mathrm{N}$ resul tou no aumento da percentagem de proteína nos grãos. Reportam ainda que ocorre uma relação inversa entre produção de grãos e o teor de proteína nos mesmos.

Estudos recentes desenvolvidos por TSAI et alii (1984) demonstraram que a produção de grãos em milho é varią vel entre os cultivares em resposta à adubação nitrogenada . Acrescentam ainda que a produção de grãos acha-se afetada por vários fatores: a) habilidade das plantas em absorver $\mathrm{O} N$ após a emissão dos cabelos da espiga; b) a duração do enchimento dos grãos; c) a taxa de síntese da zeína, a qual é influencia da pela adubação nitrogenada.

HAAG et alii (1971) estudaram o comportamento de várias populações de milho de origem brasileira, paraguaià e argentina e verificaram que a acumulação de macronutrientes é muito diferente, particularmente em relação ao nitrogênio e fósforo, em todas as partes da planta, enquanto que os outros 
nutrientes mostraram diferenças em detexminados ōrgãos(raízes, caules e folhas).

Procurando elucidar o mecanismo de absorção de ferro pelas plantas, CLARK \& BROW (1974) cultivaram separada mente e juntos em solução nutritiva, dois materiais de milho, genotípicamente diferentes um YS I/US I (ineficientes) e ou tro WF9 (eficiente). A presença da linhagem "eficiente" não beneficiou algumas substâncias redutoras para a solução. Estes autores concluíram que os fatores para "eficiência" devem agir internamente, e não externamente.

FOY \& BARBER (1958), em seus estudos com duas li nhagens de milho, encontraram um desequilíbrio na distribuição do Mg nas diversas partes das plantas. Assim uma linhagem apresentou maior teor de Mg nas folhas que outra, a qual por sua vez, apresentou maior conteúdo deste nutriente no colmo.

HALIN et alii (1968) verificaram que o grau de deficiência de zinco em milho depende do genótipo, sendo que algumas variedades apresentam deficiência mais acentuada no início do ciclo e outras no final.

Estudos realizados por BATAGLIA \& MASCARENHAS

(1977) em soja, em latossolo roxo, observaram que a concentra ção do macronutriente nas partes vegetativas e reprodutivas das plantas decresceu com a idade, exceto a concentração de nitro gênio nas sementes. Relataram ainda que a taxa máxima de maté ria seca acumulada e de nutrientes ocorreu durante o período entre o florescimento e a formação das vagens. 
Estudos realizados por BONISCHOVA (1977) em mi lho e mostarda plantada após o milho, em solos podzólicos mar rom argiloso e marrom claro de floresta, com aplicação de cho rume líquido e de fertilizantes minerais, demonstraram que o tratamento em que foi aplicado o chorume líquido apresentou melhor resultado comparativamente com aqueles que réceberam adubação com NPK na forma mineral em taxas equivalentes, espe cialmente em solo podzólico marron claro. Relataram também que a absorção de nitrogênio foi maior nos tratamentos em que foi aplicado o chorume líquido, nos dois tipos de solo.

Baseados em ensaios com batata no Irã e com ar roz nas Filipinas, GUNASENA \& AHMED (1977) recomendaram a uti lização de estercos em combinação com fertilizantes minerais para maximizar a produção das culturas, quando do estudo do efeito da aplicação ao solo de diferentes tipos de estercos, resíduos vegetais e de adubos minerais.

Relatos de PETRIKOVA (1977) em experimentos com milho e aveia realizados na Tchecoeslovaquia em solos arenosos e argilosos, atravésda utilização de esterco fresco de porco, es terco fresco associado a resíduos vegetais e de fertilizantes minerais verificou,da análise de três plantios sucessivos, que a aveia apresentou igual produção nos tratamentos com aduba ção mineral e com esterco de porco. A produção de milho apre sentou-se menor quando da utilização de esterco fresco de por co. Por outro lado, relata ainda o efeito residual do esterco, principalmente nos solos claros. 
SKARDA et alii (1977) estudaram a eficiência da adubação anual realizada na Tchecoeslovaquia, em doze campos experimentais instalados em seis locais, por um período de quatro anos, através da utilização de esterco de bovino e de suíno, numa média de 16 a $98 \mathrm{t} / \mathrm{ha}(60$ a $600 \mathrm{~kg} / \mathrm{ha}$ de $\mathrm{N})$. Con cluíram que o efeito na produção de várias culturas e no acúmulo de nitrogênio pelas plantas foi de 11 a 15\% superior nos tratamentos que receberam o adubo de origem animal, com parativamente com aqueles de origem mineral.

Experimentos foram realizados por ONISKO \& JANIC (1978) com milho, cevada, mostarda, centeio e girassol, atra vés da aplicação de biofertilizante e verificaram efeitos sa tisfatórios sobre a produção de milho, cevada e mostarda, par ticularmente quando a aplicação de biofertilizante foi neutra lizada.

KIEHL (1979), referindo a utilização de resíduos orgânicos, aponta o aspecto de saneamento ambiental no tocante à propagação de pragas e moléstias como ainda de ervas dani nhas, ressaltando portanto a necessidade de processamento dos resíduos orgânicos pelos biodigestores ou então através de técnicas de compostagem. Este mesmo autor acrescenta que os adubos orgânicos, além de agirem como fertilizantes, atuam tam bém como corretivos e melhoradores do solo.

Estudos relativos à utilização de resíduos orgâa nicos nas diferentes culturas acham-se nos trabalhos da FAO (1977), de JEWELL \& SEITZENBAUM (1978 a e b), de BOSCHI \& SI 
NISCALCHI (1979), de GOMES GUTIERREZ et alii (1979), da FAO (1980), e outros.

Alguns trabalhos como os de SOTOMAYOR (1979) ; GAUR \& MATHAR (1979); O'RIORDAN (1980); DOUGLAS et alii (1980) têm feito referências a taxas de aplicação de fertilizantes or gânicos ao solo.

FUJIYAMA et alii (1979), no Japão, estüdaram os efeitos da aplicação ao solo de esterco fresco de porco e o efeito residual do adubo orgânico sobre a produtividaảe do ar roz. Citam estes autores que no primeiro ano, com a aplicação de 25,24t/ha de esterco de porco, a produção bruta foi de

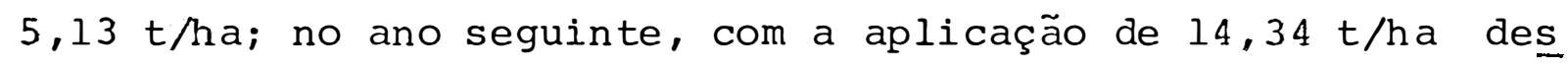
se mesmo esterco a produção foi de $4,43 \mathrm{t} / \mathrm{ha}$, denotando-se os efeitos residuais do esterco de porco.

Resultados interessantes foram apontados por SA $\underline{R}$ KADI et alii (1979) de experimentos desenvolvidos durante vá rios anos em solos do vale do Rio Danúbio, na Hungria, quanto aos efeitos diretos e residuais do fósforo, derivados da aplí cação de resíduos orgânicos. Relataram que estes são semelhan tes aos efeitos da aplicação de superfosfato sem rotação com leguminosas.

SILVA (1979) cita que estudos realizados em paí ses desenvolvidos têm demonstrado alguns problemas causados pelo uso intensivo de fertilizantes minerais, sem a integra ção com os orgânicos, necessários sob o aspecto pedológico co mo também o econômico. Enfatiza que ōrgãos oficiais, especial 
mente $O$ IBC, têm recomendado a utilização de matéria orgânica como estercos, torta de algodão, de mamona e palha de café ; porém faz referência quanto ao perigo da utilização de maté ria orgânica de fonte desconhecida, a qual poderá ocasionar a introdução de ervas daninhas,pragas e moléstias.

Estudos comparativos sobre a eficiência da adu bação orgânica e da mineral em hortaliças foram realizados por SOTOMAYOR (1979), o qual constatou o acúmulo de matéria orgâa nica, fósforo e potássio no solo naqueles tratamentos em que se fez uso do composto, enquanto que houve acúmulo de fósforo nos tratamentos com fertilizante mineral, quando da utilizą ção de altas doses.

Conforme relataram ASMUS et alii (1979), em ex perimentos a longo prazo, a aplicação de matéria orgânica fạ vorece o teor de humus do solo, condicionando alta produtivi dade às culturas.

Estudos foram realizados por DELPHIN \& CONESA (1979) por um período de dez anos, analisando-se o efeito da rotação de cultura, irrigação e incorporação de resíduos de ma téria orgânica ao solo, tendo-se observado um aumento signifí cativo no teor de matéria orgânica. Relataram ainda que o teor de matéria orgânica e o valor da relação $\mathrm{C} / \mathrm{N}$ aumentaram com a inclusão de luzerna (leguminosa semelhante à alfafa) nas rotạ ções, porém houve um decréscimo com a utilização da irrigação. Comparações sobre as respostas dos vários fertí lizantes foram realizadas por MAZUR et alii (1979) na Polônia, 
utilizando-se do chorume de bovino, chorume de porco, resíduos vegetais e fertilizantes minerais. Observaram que houve um au mento na produção das culturas pela aplícação de chorume de porco e de bovino, e as melhores respostas foram obtidas na cultura do milho. Relataram ainda que o chorume de bovino mos trou maior eficiência em solos arenosos enquanto que o de porco, em solos argilosos. O chorume de bovino foi mais eficiente para o primeiro plantio que os resíduos vegetais, enquanto que es tes apresentaram maior eficiência para as culturas posteriores. A adubação mineral adequada não foi superada, em maior prodụ ção, por nenhum tratamento contendo esterco.

Acham-se relatados alguns trabalhos quanto à uti lização de esterco de galinha como fertilizante. Assim WEIL \& KROOTJE (1979) observaram, por cinco anos consecutivos, dife renças marcantes nas parcelas cultivadas com milho, aplican do-se 110 t/ha/ano quando comparadas com aquelas mantidas como testemunha. Estudos feitos por TEMPLE-SMITH (1979) em pasta gens revelaram que a aplicação de 2 t/ha de esterco de gali nha contendo $2,2 \%$ de $N, 1,4 \%$ de $\mathrm{P}$ e $0,7 \%$ de $\mathrm{K}$, resultou em maior vigor da pastagem, comparativamente à adubação mineral . Acrescenta ainda que, através da aplicação de 32 t/ha de ester co de galinha, ocorreu uma produção superior, da ordem de 8 vezes; comparativamente com aquela em que se usou adubo mine ral. MASCARENHAS et alii (1980) investigaram o efeito do ester co de galinha sobre a cultura de soja, em três anos consecuti vos e concluiram que nos dois primeiros anos de cultivo não 
houve diferenças entre a adubação verde e a adubação orgânica, porém a partir do terceiro ano os resultados foram superiores na produção de soja com a utilização da adubação orgânica.

Também AMBERGER et alii (1980) e e BUGUSLAWSKI

(1980) reportaram que na Alemanha o composto de esterco so frendo manejo adequado em solos arados poderá ser aplicado em quantidades de 50 a $100 \mathrm{~m}^{3} / \mathrm{ha}$ em ciclos de 2 a 3 anos, sendo que a aplicação deverá ser antecipada ao cultivo, evitando portantó relações fisiológicas desfavoráveis, porém alcan Çando enriquecimento de nutrientes, especialmente, N,P, Ca e Mg. Os efeitos da aplicação de qrandes quantidades de chorlume ão solo, sobre o acúmulo de macronutrientes, foram estudados em dois anos consecutivos por HUNDT \& GORLITZ(1980), durante o período de crescimento do milho, trigo de inverno, centeio, tomate e beterraba açucareira. Relataram que as par celas de milho receberam NPK ou chorume em quantidades equiva lentes a 1200 e $1800 \mathrm{~kg} / \mathrm{ha}$ de $\mathrm{N}$, sendo que nos tratamentos em que foi aplicado o chorume, observou-se maior acúmulo de N, P e $\mathrm{K}$ nas folhas e menor acúmulo de $\mathrm{Ca}$ e $\mathrm{Mg}$, enquanto que a pro dução diminuiu quando altas taxas foram aplicadas. Nas parce las com trigo de inverno e centeio foram aplicados N, P e K ou chorume em quantidades equivalentes a 250 ou $350 \mathrm{~kg} / \mathrm{ha}$ de $\mathrm{N}$ verificando-se que no trigo houve maior acúmulo de $\mathrm{N}$, Ca e Mg naquelas parcelas que receberam chorume comparativamente com aquelas em que foi aplicada apenas a adubação mineral, en quanto que os tratamentos no centeio não diferiram quanto ao 
teor de macronutrientes nos grãos. Relatam ainda que a produ ção de grãos foi maior quando se utilizou de pequenas quantí dades de chorume, comparativamente com os tratamentos em que foram aplicados fertilizantes minerais. Foram utilizados para tomateiro 400 e $600 \mathrm{~kg} / \mathrm{ha}$ de $\mathrm{N}$, e para beterraba açucareira $600 \mathrm{e} 1000 \mathrm{~kg} / \mathrm{ha}$ de $\mathrm{N}$. Estes tratamentos em contraste com aqueles que receberam adubação mineral, não proporcionaram di ferenças no acümulo de macronutrientes nas folhas como tambëm na produção.

Alguns estudos realizados na Alemanha por HUNDT \& GORLITZ (1980) têm demonstrado o efeito da aplicação do chio rume ao solo sobre várias culturas. A aplicação do chorume em quantidades equivalentes a $1.200 \mathrm{~kg} / \mathrm{ha} \mathrm{em}$ milho resultou em maior acúmulo em NPK nas folhas na ordem $\mathrm{K} P \mathrm{~N}$ e menor de Ca e Mg do que nos tratamentos que não receberam o chorume. Apontam também a aplicação de $250 \mathrm{~kg} / \mathrm{ha}$ de chorume ao solo, em ensaios realizados com trigo e centeio, sendo que nos resultados apre sentados em centeio foram não significativas as diferenças quanto ao acúmulo de nutrientes nos grãos; enquanto que no trigo, os tratamentos que receberam o esterco apresentaram maior teor de $\mathrm{K}$ e menores teores de $\mathrm{N}$, Ca e Mg, comparativa: mente com aqueles que receberam adubação mineral.

A eficiência da aplicação do fertilizante de ori gem animal quanto à época de aplicação foi estudada por EFRE MOV (1980) em solo argiloso em várias épocas do outono, cons tatando-se que a aplicação do composto esterco-turfa na pro 
porção de 1:I nã̃o diminui a efetividade do fertilizante, con tribuindo satisfatoriamente na fertilidade do solo e incremen tando as produções de batatinha, cevada e aveia. Quanto ao es terco de galinha, verificou este autor, que o mesmo apresen tou menor eficiência quando aplicado no outono do que na prima vera. POr outro lado, KREJCIR \& RIMOVSKY (1980) observaram o efeito do chorume de porco, constatando que ocorreu redução na porosidade total e aumento na densidade do solo e a aplica ção de grandes quantidades, assim como a frequência elevada, provocaram compactação do solo e maior dificuldade para o cul tivo. Apontam estes autores que estes efeitos adversos decor rentes da aplicação do chorume devem ser controlados para que se possa cultivar o solo mais intensamente. 
3. MATERIAI E METODOS

\section{I. Solo}

A presente pesquisa foi conduzida no município de Jaboticabal - SP, em ärea experimental da Faculdade de Ciên cias Agrárias e Veterinárias - UNESP, no ano agrícola 84/85, num solo classificado como Latossol Vermelho Escuro - "fase a renosa" (COMISSÃO DE SOLOS, 1960), sērie Santa Teresa, segundo ALOISI e DEMATTE (1974), cuja análise química para fins de fertilidade acha-se apresentada no Quadro 1.

Quadro 1 - Resultados da Análise Química da Camada Superficial do Solo*.

\begin{tabular}{|c|c|c|c|c|c|c|c|c|c|}
\hline \multirow{2}{*}{$\begin{array}{c}\mathrm{P} \\
\text { resina } \\
\mathrm{mg} / \mathrm{cm}^{3}\end{array}$} & \multirow[b]{2}{*}{$\begin{array}{c}\text { M.O } \\
\% \\
\end{array}$} & \multirow{2}{*}{$\begin{array}{c}\mathrm{P}^{\mathrm{H}} \\
\mathrm{H}_{2} \mathrm{O}\end{array}$} & \multirow[t]{2}{*}{$\mathrm{K}$} & $\mathrm{Ca}$ & $\mathrm{Mg}$ & $H+A I$ & $S$ & \multirow[t]{2}{*}{$\mathrm{T}$} & \multirow{2}{*}{$\begin{array}{l}\mathrm{V} \\
\circ\end{array}$} \\
\hline & & & & & neq/100 & $\mathrm{cm}^{3}$ & & & \\
\hline 1 & 1,29 & 5,8 & 0,48 & 3,1 & 0,8 & 2,0 & 4,38 & 6,38 & 68,6 \\
\hline
\end{tabular}

* Anālises realizadas segundo mëtodos descritos por RAIJ \& QUAGGIO (1983). 
3.2. Sementes, Semeadura e Desbastes

A semeadura dos diversos materiais de milho foi realizada em 28 de novembro de 1984, empregando-se 10 sementes por metro linear de sulco.

Foram tilizados cinco materiais geneticamente diferentes, cujas principais características são as seguintes:

\section{Piranão VD. 2'}

No presente trabalho esta população será denơmi nada de Piranão, de grãos dentados amarelos, que resultou, em primeiro lugar, da seleção para porte médio a partir da gera ção $\mathrm{F}_{2}$ do cruzamento da população ESALQ VD. 2' $x$ Piranão VD. l'. A população VD.l' foi obtida da geração $\mathrm{F}_{2}$ do cruzamento Piramex x Tuxpeño br 2. Estes dois materiais são milho dentado, o primeiro amarelo e o outro branco, da raça Tuxpeño, origi nalmente introduzido no CIMMYT.

2. Híbrido Duplo (HD 7974)

Atualmente è um dos híbridos mais utilizados pe los agricultores do Estado de são Paulo, caracteriza-se por ser um híbrido duplo semi-dentado obtido pelo Instituto Agro nômico de Campinas, em meados de 1958, a partir de linhagens brasileiras e mexicanas. 
3. Composto Flint (C.F.)

E uma população originalmente formada por várias populações de milhos duros e amarelos, originārias da América Central (especialmente Cuba), Colombia e Brasil. Foi submeti da a ciclos de seleção e o material melhorado para produção, sendo que os últimos ciclos foram utilizados no presente trạ balho.

4. Composto Dentado (C.D.)

População obtida originalmente a partir de amos tras de milho branco e amarelo de germoplasma do México, Costa Rica e do Brasil. A população base foi multiplicada e melhora da a partir de 1968 e, no presente trabalho, as sementes do último ciclo é que foram utilizadas.

5. Dinamilho 10 (Dina 10)

Caracteriza-se por ser um híbrido duplo semidentado, desenvolvido pela LIMA-GRAIN DO BRASIL, estando a nI vel de comercialização, junto aos agricultores, há aproximą damente três anos.

A emergência das plântulas ocorreu oito dias após a semeadura, sendo o desbaste efetuado 19 dias após, de $\underline{i}$ xando-se cinco plantas por metro linear. 
3.3. Delineamento Experimental e Tratamentos

o delineamento experimental utilizado foi em blo cos casualizados com cinco tratamentos e oito repetições, sen do quatro blocos com fertilizante mineral e quatro com ferti. lizante orgânico.

Os tratamentos foram caracterizados por uma cul tivar de milho, conforme descrito no item 3.2.

A adubação mineral correspondeu à aplicação no sulco de semeadura de $250 \mathrm{~kg} / \mathrm{ha}$ da förmula $4-31-16+\mathrm{Zn} \mathrm{(2 \% )} \mathrm{e}$ $50 \mathrm{~kg} / \mathrm{ha}$ de $\mathrm{N}$ aos 37 dias após a emergência das plântulas. A fonte de nitrogênio utilizada em cobertura foi o sulfato de amônio.

Foi utilizado como fonte de adubo orgãnico efluente de biodigestores resultante da fermentação anaeróbica de estrume de bovino diluído em āgua. O teor de āgua e a com posição química deste material com base na matéria seca achase apresentada no Quadro 2.

Quadro 2. Composição do Efluente de Biodigestor Utilizado

\begin{tabular}{|c|c|c|c|c|c|c|c|c|c|c|c|}
\hline Água & $\mathrm{N}$ & $\mathrm{P}$ & $\mathrm{K}$ & $\mathrm{Ca}$ & $\mathrm{Mg}$ & $S$ & $B$ & $\mathrm{Cu}$ & $\mathrm{Fe}$ & $\mathrm{Mn}$ & $\mathrm{Zn}$ \\
\hline 웅 & & & & & & & & & ppm & & \\
\hline 94 & 2,51 & 0,88 & 1,17 & 0,93 & 0,41 & 0,31 & 278 & 70 & 7395 & 637 & 5041 \\
\hline
\end{tabular}


o efluente de biodigestor foi empregado na dose de $40 \mathrm{~m}^{3} / \mathrm{ha}$, sendo a sua aplicação realizada seis dias antes da semeadura, através de regadores sem o crivo, em sulcos abe $\underline{r}$ tos, a 10 centímetros de distância do sulco de semeadura.

Através da Figura 1, pode-se observar a distrí buição dos diversos tratamentos e dos respectivos blocos expementais.

Cada parcela, que correspondia a um material de milho, era constituída de 10 linhas espaçadas de 1,0 metro, com comprimento de $8,0 \mathrm{~m}$, abrangendo uma área total de 80,0 $\mathrm{m}^{2}$ e uma área útil de $48,0 \mathrm{~m}^{2}$, pois quatro linhas representa ram as bordaduras. Pela Figura 2, pode-se observar 0 esquema detalhado de uma parcela. 


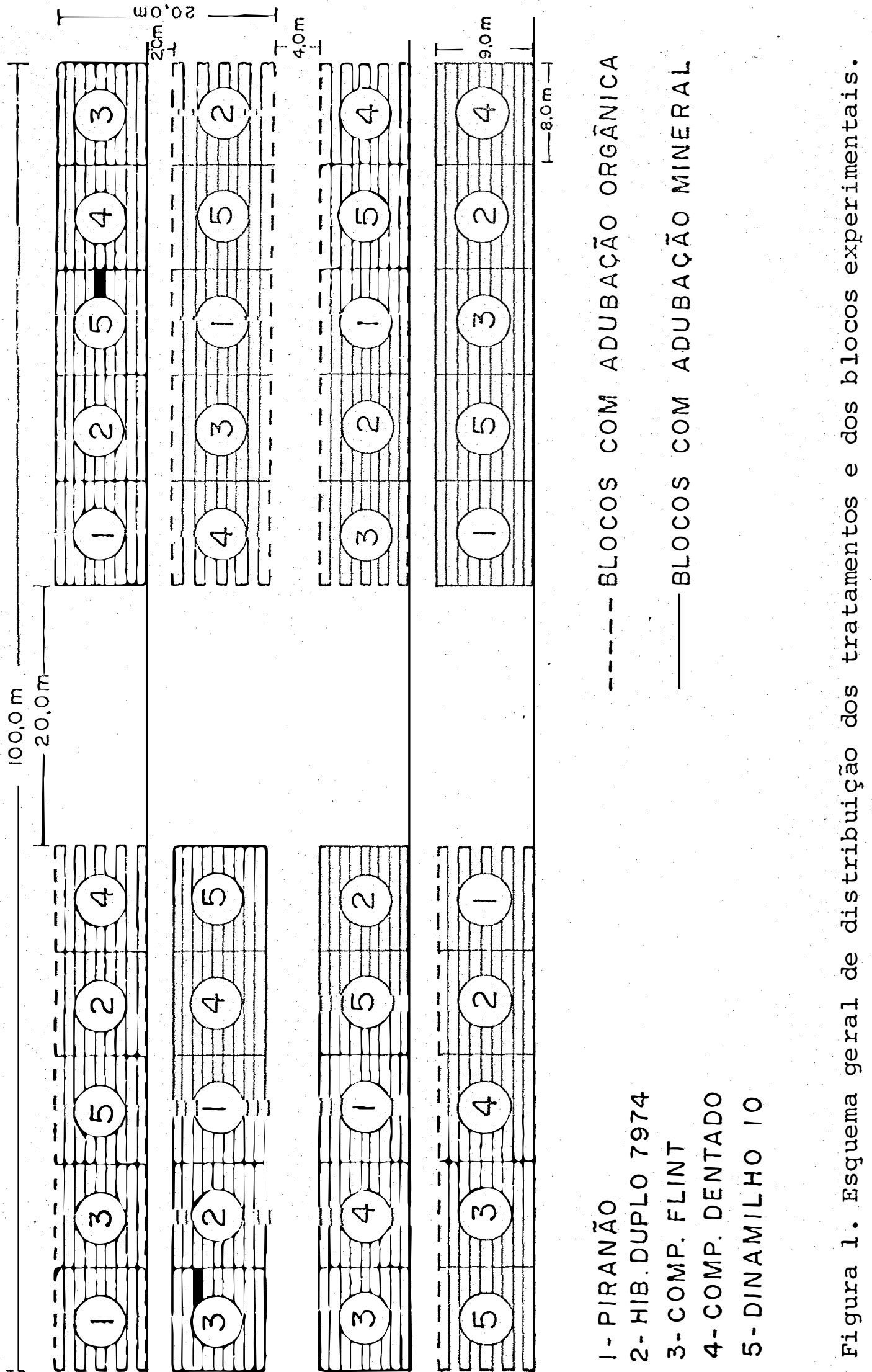



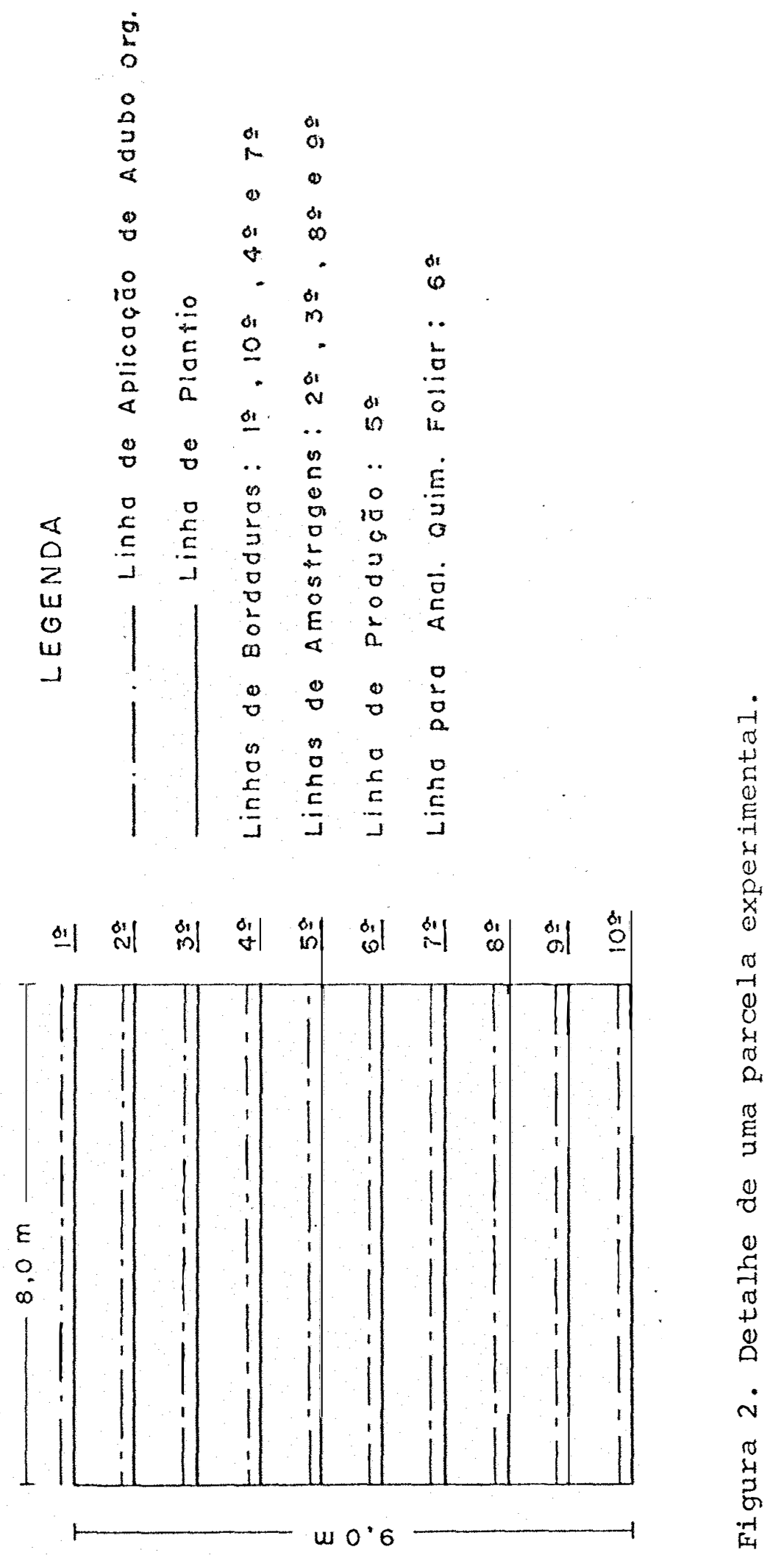


\subsection{Observações Climatológicas}

Com o objetivo de informar as condições climato lógicas a que ficou submetida a cultura, são aṕresentados em Apên dice alguns dados fornecidos pelo posto agroclimatológico des te Campus, relativos ao período de novembro de 1984 à maio de 1985 .

\subsection{Anālise do Desenvolvimento da Cultura}

\subsubsection{Altura das Plantas}

Para análise deste parâmetro, dos diversos cultiva res de milho, em estudo, realizaram-se amostragems em intervalos quin zenais que se prolongaram: até aos 105 dias após a semeadura.

A determinação da altura das plantas que foi realizada com o auxilio àe uma régua graduada em centimetro, compreendia o intervalo entre a superfície do solo e o ponto de inserção do limbo foliar da folha mais alta. Estas avalia ções foram realizadas em dez plantas das linhas de amostragens, em cada uma das parcelas. 


\subsubsection{Número de Eolhas}

Para avaliação deste parâmetro efetuou-se a con tagem do número de folhas totalmente desenvolvidas, nos mes mos intervalos, de amostragens descritos anteriormente, em dez plantas, tomadas ao acaso, em cada uma das parcelas.

\subsection{3. Área Foliar}

Para estimativa da ārea foliar analisaram-se 12 plantas por tratamento, com três plantas de cada parcela, efe tuando-se o produto do maior comprimento pela maior largura, multiplicando-se pelo fator de correção 0,75 (CARLETON \& FOOTE, 1975), proposto para a cultura do milho.

\section{3,5.4. Acumulação de Matéxia Seca}

Das linhas reservadas para amostragens, tomaramse três plantas, ao acaso, em cada uma das parcelas, observan do-se sempre o aspecto competitivo entre plantas, em cada amos tragem. Apōs serem cortadas na região do colo, as plantas foram levadas ao laboratório sendo lavadas e dessecadas em colmo, bainha, lâminas foliares, inflorescência masculina e inflores cência feminina. As amostragens, para avaliação deste parâme tro, foram realizadas adotando-se o mesmo período e interva los seguidos para a determinação da altura das plantas, cita dos anteriormente. 


\section{5 .4 .1 . Colmo}

Após a dessecagem das 12 plantas por tratamento, o mateirial correspondente aos colmos foi medido e colocado em sacos de papel, individualizados por parcela, sendo levados para uma estufa de aeração forçada marca FANEM, modelo 330/5, à temperatura de 709C. Após secagem completa, o material foi pesado em balança METTER modelo PN 1210, com capacidade para 1210 gramas e precisão de 0,01 grama.

\subsubsection{Bainha}

Para avaliação do teor de matéria seca acumula da nas bainhas, tomou-se este material já separado do resto das plantas em 12 plantas por tratamento, colocou-se em sacos de papel, também individualizados por parcela, e seguiu-se a mesma metodologia descrita na determinação da matéria seca acū mulada nos colmos.

\subsubsection{Lâminas Foliares}

Para a determinação do teor de matéria seca acu mulada nas lâminas foliares, seguiu-se a mesma metodologia des crita anteriormente, no caso dos colmos e bainhas, sendo as lâminas foliares acondicionadas em sacos de papel, individua lizados por parcela, e colocados em estufa até secagem completa. 


\subsubsection{Inflorescência Masculina}

Por ocasião do florescimento das plantas, sepa rou-se a inflorescência masculina de 12 plantas por tratamen to, de três plantas das linhas de amostragem por parcela, sen do posteriormente acondionadas em sacos de papel e levadas à estufa até peso constante. Para avaliação deste parâmetro fô ram realizadas amostragens aos 45, 60, 75, 90 e 105 dias após a semeadura.

\subsubsection{Inflorescência Feminina}

As amostragens das plantas, para avaliação deste parâmetro, foram realizadas no mesmo período citado para deter minação da matéria seca na inflorescência masculina. Utilizouse a mesma metodologia usada para a determinação da matéria se ca dos outros cultivares citados anteriormente.

\subsubsection{Acumulação da Matéria Seca Total}

De posse dos dados de acumulação da matéria se ca das diversas partes das plantas, proceaeu-se à somatória destes valores para se obter o valor da acumulação de matéria seca total das 12 plantas por tratamento, em três plantas por parcela. 


\subsubsection{Diagnose Foliar}

Para se avaliar o estado nutricional das plantas, foi utilizada a técnica da diagnose foliar para a cultura do milho descrita por TRANI et alii (1983).

A amostragem de folhas foi realizada $70:$ dias apös a emergência das plantas, coletando-se de 30 plantas, por parcela, os $30 \mathrm{~cm}$ do terço basal (sem a nervura central) da quarta folha a partir do ápice (folhas +4 ), cuja inserção da bainha com o colmo era visível.

\subsubsection{Análises Químicas das Folhas}

Para a determinação das concentrações de N, P, K, $\mathrm{Ca}, \mathrm{Mg}, \mathrm{Cu}, \mathrm{Fe}, \mathrm{Mn}$ e $\mathrm{Zn}$ nas folhas, foram utilizados métodos descritos por BATAGLIA et alii (1978).

\subsection{Avaliação da Produção}

Por ocasião da colheita, com o teor de umidade dos grãos em 14\%, nas 10 plantas reservadas na linha de prodụ ção, foi colhida a espiga principal de cada planta, acondicio nadas em sacos de plásticos identificadas por tratamento e levada ao laboratório a fim de serem separadas da palha e efe tuadas as determinações previstas. 
3.6.1. Comprimento das Espigas

Utilizando-se uma fita métrica graduada em cen tímetro, determinou-se o comprimento da ponta até a base da es piga, nas 10 espigas tomadas por parcela.

\subsubsection{Circunferência das Espigas}

Para avaliação da circunferência das espigas to mou-se a região mediana e com uma fita métrica determinou - se este valor expresso em centímetros.

3.6.3. Número de Fileiras de Grãos por Espiga

Fez-se a contagem do número de fileiras, naque las espigas em que foi avaliada a produção.

\subsubsection{Número de Grãos por Fileira}

Contou-se o número de grãos por fileira, naque las espigas em que foram determinados os nūmeros de fileiras por espiga.

\subsubsection{Peso da Espiga Principal}

Após a retirada das folhas, as espigas foram pe 
sadas em balança Filizola com capacidade de $1 \mathrm{~kg}$ tendo precí são em l grama. O peso das espigas foi expresso em gramas.

\subsubsection{Peso de Quinhentos Grãos}

Apōs serem pesadas as 10 espigas das 10 plantas por parcela, fez-se a debulhação manual e prccedeu-se à sepa ração de 500 grãos que foram em seguida pesados na mesma bạ lança utilizada para determinação do peso das espigas; seus va lores encontram-se expressos em gramas.

\subsection{Análise Qualitativa da Produção}

\subsubsection{Proteĩna Total dos Grãos}

Foram utilizacoos aqueles grãos em que se avaliou a produção, e, para análise deste parâmetro, foi utilizada a metodologia descrita pela A.O.A.C. (1970), sendo seus valores expressos em porcentagem. 


\section{RESULTADOS E DISCUSSŐES}

Em decorrência dos parâmetros analisados e para facilidade de apresentação, serão apresentados e discutidos os dados obtidos, sempre que possivel, na mesma sequência apresentada a partir do item 3.4 .

\subsection{Observações Climatológicas}

A Figura 3 mostra os valores de precipitação ob servados durante o período de desenvolvimento da pesquisa, ou seja, de novembro de 1984 a maio de 1985. Pode-se observar também pelas Tabelas 1, 2, 3, 4 e 5 do apēndice, que a preci pitação total neste período foi de $1213,1 \mathrm{~mm}$, para uma média anual estimada para a região de Jaboticabal da ordem de $1271,0 \mathrm{~mm}$.

Conforme pode-se constatar, o ciclo inicial do desenvolvimento da cultura esteve submetido a condições de al ta precipitação e, conseqüentemente, em condições de alta umi dade do solo. 


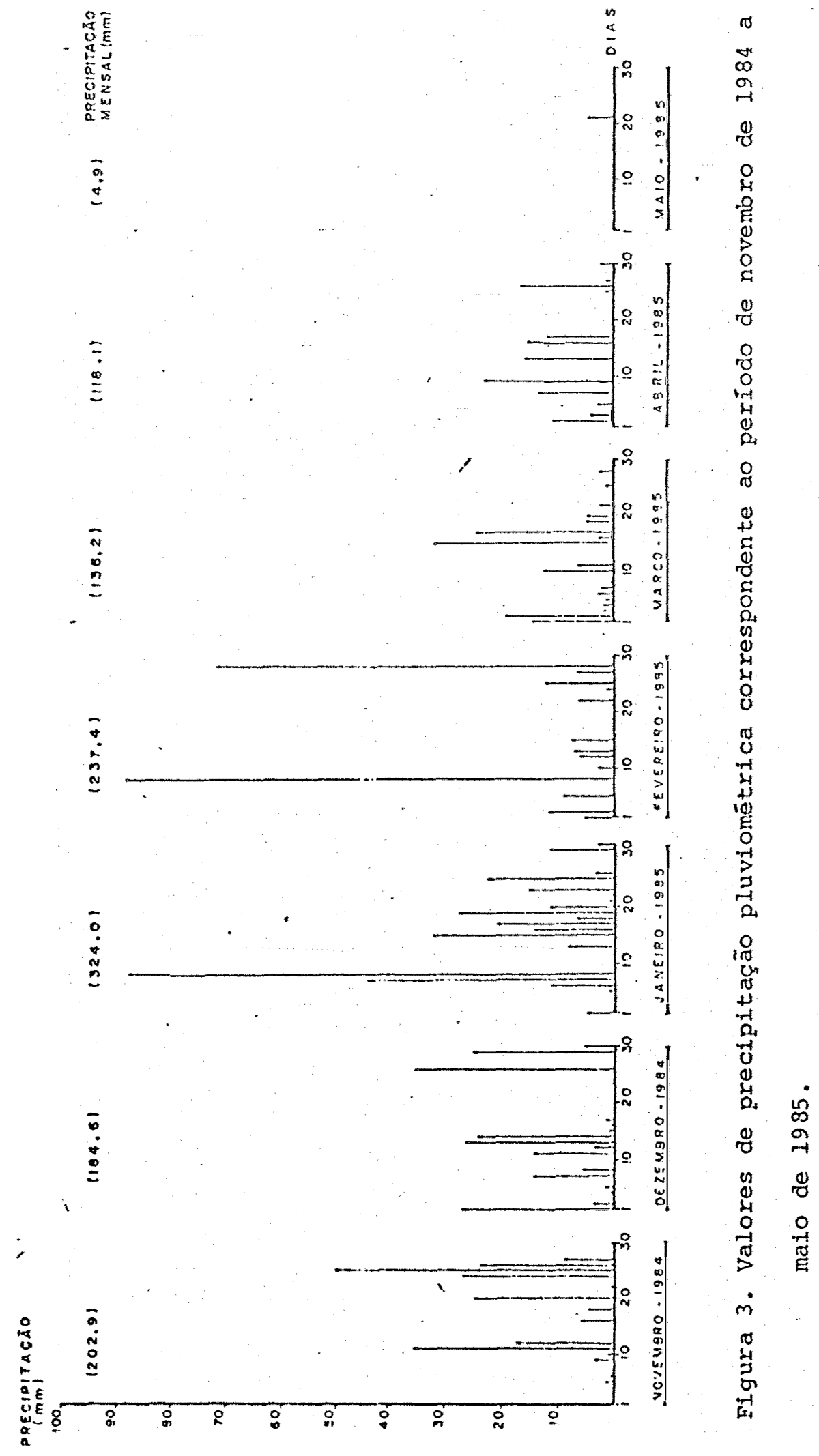




\subsection{Altura das piantas}

Através do Quadro 3 pode-se observar que os va lores de F foram de modo geral, não significativos, quando se analisa o componente Adubos, com exceção da análise aos 30 dias após a semeadura, na qual o teste $F$ apresenta-se com vâ lor significativo e a altura média para o fertilizante orgâní co, de $35,94 \mathrm{~cm}$, foi superior à do mineral $(32,19 \mathrm{~cm})$.

Dentre os diversos materiais de milho utiliza dos, os valores de $\mathrm{F}$ apresentaram-se significativos, ao longo de todo período de amostragem, quando se observa 0 com ponente Piranão vs Demais, e pelas médias dos materiais, ve rifica-se que o Piranão aparece sempre com um valor médio me nor que os demais, ou seja, com plantas de porte inferior. Is to era de se esperar, visto que o Piranão foi selecionado, ge neticamente, para apresentar plantas de porte médio inferior aos demais materiais de milho existentes no comércio. Confor me cita MIRANDA FILHO (1978), a seleção para a redução do por te da planta pode ser altamente eficiente em populações, utí lizando-se de esquemas simples de seleção.

Para o componente Híbridos vs Compostos, obse $\underline{\underline{r}}$ va-se que os valores de $\mathrm{F}$ foram significativos em todas as amostragens, sendo que os Compostos apresentaram sempre valo res médios superiores ao dos Híbridos ao longo de todo o pe ríodo de amostragem.

Analisando o comportamento dos Híbridos, obser 
va-se que os valores de F foram, na maioria das amostragens, não significativos, sendo que somente aos 30 dias após a semeadura este valor foi significativo. Observando-se as médias destes cultivares, verifica-se que o Hibrido Duplo apresenta, valores superiores ao híbrido Dina 10, na amostragem aos 30 dias após a semeadura.

Com relação aos Compostos, observa-se que os valores de $F$ foram não significativos aos 30, 75, 90 e 105 dias e significativos aos 45 e 60 dias após a semeadura.Pelas médias para estes materiais, verifica-se que o Composto Flint apresenta, aos 45 e 60 dias, valores superiores aos do compos to Dentado, com relação à altura das plantas. Observou--se que, no geral, os Compostos foram superiores aos demais tratamen tos, resultados esses semelhantes aos observados por PAIER NIANI (1968).

Analisando as médias dos diversos materiais de milho utilizados, verifica-se que quanto à altura das plan tas, os maiores incrementos no desenvolvimento deste parâme tro, foram observados, de modo geral, até aos 75 dias após a semeadura, tornando-se menos pronunciados nas amostragens seguintes, ou seja, aos 90 e 105 dias.

Quanto à interação A X M observa-se que os valores de F, ao longo de todo o período de amostragem, foram não significativos. 
Quadro 3 . Valores de F, coeficientes de variação, médias dos materiais e médias dos adubos, para os dados de al tura das plantas $(\mathrm{cm})$, nas diversas amostragens.

\begin{tabular}{|c|c|c|c|c|c|c|}
\hline \multirow{2}{*}{$\begin{array}{l}\text { Causas de } \\
\text { Variação }\end{array}$} & \multicolumn{6}{|c|}{ Dias após a semeadura } \\
\hline & 30 & 45 & 60 & 75 & 90 & 105 \\
\hline Adubos (A) & $16,08 * *$ & $2,35^{\mathrm{ns}}$ & $2,74^{\mathrm{ns}}$ & $3,07^{\mathrm{ns}}$ & $3,12^{\mathrm{ns}}$ & $1,02^{\text {ns }}$ \\
\hline Piranão vis Demais & $26,45 * \star$ & $16,43 * *$ & $72,41 * *$ & $242,85 * *$ & $103,32 * *$ & $132,67 * *$ \\
\hline Húbriơos vs Compostos & $4,23^{* *}$ & $5,29 *$ & $5,24 *$ & $13,75 * *$ & $35,41 * *$ & $16,85 * *$ \\
\hline H.D. vs Dina 10 & $8,85 * *$ & $0,62^{\mathrm{ns}}$ & $0,03^{\text {ns }}$ & $2,59^{\text {ns }}$ & $0,12^{\text {ns }}$ & $0,25^{\text {ns }}$ \\
\hline C.F. vs C.D. & $0,01^{\mathrm{ns}}$ & $4,79 *$ & $4,55^{*}$ & $1,48^{\text {ns }}$ & $2,86^{\mathrm{ns}}$ & $0,45^{\mathrm{nS}}$ \\
\hline Interação A $\times$ M & $1,54^{\mathrm{ns}}$ & $0,44^{\text {ns }}$ & $0,68^{\text {ns }}$ & $0,53^{\text {ns }}$ & $1,50^{\mathrm{ns}}$ & $0,54^{\text {ns }}$ \\
\hline C.V. ( () & 8,68 & 12,24 & 10,07 & 6,06 & 6,90 & 6,65 \\
\hline
\end{tabular}

Médias dos Materiais

\begin{tabular}{lllllll}
\hline Pixanão & 29,25 & 58,50 & 97,21 & 142,19 & 144,13 & 142,00 \\
H.D. & 36,39 & 70,32 & 136,40 & 192,18 & 185,56 & 191,25 \\
C.F. & 36,28 & 80,20 & 154,97 & 205,75 & 209,75 & 209,88 \\
C.D. & 36,40 & 70,91 & 140,65 & 198,95 & 198,94 & 205,69 \\
Dina 10 & 31,99 & 66,98 & 137,49 & 183,19 & 187,65 & 188,14 \\
\hline Medias dos Adubos & & & & & & \\
\hline Mineral & 32,19 & 71,44 & 136,86 & 187,55 & 188,78 & 185,40 \\
Orgânio & 35,94 & 67,32 & 129,83 & 181,35 & 181,64 & 189,38 \\
\hline
\end{tabular}

ns = não significativo $(P>0,05)$

* = significativo $(P<0,05)$

$\star \star=$ significativo $(P<0,01)$ 


\subsection{Nünero de Folhas}

No Quadro 4, que refere-se as anālises para o número de folhas nos diversos materiais de milho, observa- se que os valores de F, com relação aos Adubos, foram ao longo de todo o período de amostragem não significativos, indican do que o tipo de fertilizante utilizado não interferiu neste parâmetro.

Analisando os materiais, para o componente $\mathrm{P} \underline{\mathbf{i}}$ ranão vs Demais, verifica-se que não ocorreu diferença signi ficativa nos períodos de 30, 45 e 75 dias após a semeadura, ao passo que aos 60, 90 e 105 dias após a semeadura, o teste mostrou diferenças significativas. Pelas médias, observa - se que o Piranão apresenta-se, geralmente, com valores inferio res à média dos demais, e estes resultados concordam com ROOD \& MAJOR (1981) que verificaram a existência de uma diminuição no número de folhas em materiais precoces.

Observando o componente Híbridos vs Compostos, verifica-se que as diferenças não foram significativas aos 30, 45 e 105 dias e significativas aos 60, 75 e 90 dias após a semeadura. Analisando as médias, verifica-se que os híbrí dos apresentam, de modo geral, valores médios menores que aqueles observados nos Compostos. Dentre os Híbridos, depreen de-se que o Híbrido Duplo apresenta-se com valores superio res aos do Dina 10, com relação ao número de folhas, apenas aos 30 dias após a semeadura. 
Com relação aos Compostos, verifica-se que

○

Composto Flint apresenta-se com valor superior ao do Composto Dentado apenas aos 75 dias após a semeadura.

Conforme relataram CROSS \& ZUBER (1973) em mi 1ho, o número de folhas por planta constitui um índice de classifícação para a maturidade, pois tem sido observada uma correlação positiva entre o número de folhas e dias para a antese. Também os trabalhos de CHASE \& NANDA (1967); ROOD \& MAJOR (1981) relataram a ocorrência de uma estreita relação entre o número de folhas e o período de florescimento. Por outro lado, HESKETH et alii (1969) já apontaram que o número de folhas em milho difere com o genótipo.

Com relação à interação AxM observa-se, pelos valores de $F$, que as diferenças não foram significativas ao longo de todo o perĩodo de amostragem, com relação ao parâmetro número de folhas. 
Quadro 4. Valores de $F$, coeficientes de variação, mëdias dos materiais e médias dos adubos, para os dados de número de folhas, nas diversas amostragens.

\begin{tabular}{|c|c|c|c|c|c|c|}
\hline \multirow{2}{*}{$\begin{array}{l}\text { Causas de } \\
\text { Variação }\end{array}$} & \multicolumn{6}{|c|}{ Dias após a semeadura } \\
\hline & 30 & 45 & 60 & 75 & 90 & 105 \\
\hline Adubos (A) & $1,55^{\text {ns }}$ & $2,41^{\text {ns }}$ & $1,97^{\text {ns }}$ & $0,04^{\mathrm{nS}}$ & $1,95^{\text {ns }}$ & $0,33^{\mathrm{ns}}$ \\
\hline Piranão vs Demai.s & $0,37^{\mathrm{ns}}$ & $0.42^{\mathrm{ns}}$ & $10,83 * *$ & $2,82^{\mathrm{ns}}$ & $6,92^{*}$ & $15,85 * *$ \\
\hline Híbridos vs Compostos & $0,00^{\text {ns }}$ & $3,51^{\mathrm{ns}}$ & $11,75 * *$ & $26,89 * *$ & $12,94 * *$ & $2,14^{\mathrm{ns}}$ \\
\hline H.D. vs Dina 10 & $8,36^{* *}$ & $0,55^{\mathrm{ns}}$ & $0.20^{\mathrm{ns}}$ & $0,23^{\mathrm{ns}}$ & $0,02^{\text {ns }}$ & $0,05^{\mathrm{ns}}$ \\
\hline C.F. vs C.D. & $0,04^{\mathrm{ns}}$ & $1,42^{\text {ns }}$ & $0,41^{\mathrm{ns}}$ & $4,75^{\star}$ & $0,22^{\mathrm{ns}}$ & $0,07^{\text {ns }}$ \\
\hline Interação A X M & $0,87^{\text {ns }}$ & $0,44^{\mathrm{ns}}$ & $0,29^{\mathrm{ns}}$ & $0,79^{\mathrm{ns}}$ & $0,50^{\text {ns }}$ & $2,58^{\mathrm{ns}}$ \\
\hline C.V. $(q)$ & 11,70 & 10,56 & 6,08 & 3,98 & 7,40 & 7,78 \\
\hline
\end{tabular}

Médias dos Materiais

\begin{tabular}{lllllll}
\hline Piranäo & 6,54 & 8,12 & 10,25 & 11,57 & 10,77 & 9,53 \\
H.D. & 7,29 & 7,79 & 10,79 & 11,51 & 11,08 & 10,65 \\
C.F. & 6,76 & 8,44 & 11,63 & 12,58 & 12,10 & 11,08 \\
C.D. & 6,68 & 7,94 & 11,41 & 12,06 & 12,30 & 10,98 \\
Dina 10 & 6,16 & 7,48 & 10,63 & 11,40 & 11,15 & 10,56 \\
\hline
\end{tabular}

Médias dos Adubos

\begin{tabular}{lllllll}
\hline Mineral & 6,84 & 8,11 & 10,80 & 11,84 & 11,67 & 10,64 \\
Orgânico & 6,53 & 7,80 & 11,09 & 11,81 & 11,30 & 10,49 \\
\hline
\end{tabular}

ns $=$ não significativo $(P>0,05)$

* = significativo $(P<0,05)$

$\star \star=$ significativo $(P<0,01)$ 


\section{4. Ārea Foliar}

Pela análise do Quadro 5, observa-se que

os valores de $\mathrm{F}$ relativos aos Adubos, em todas as amos tragens realizadas, não se apresentaram significativos, indí cando que o tipo de fertilizante não influi na área foliar das plantas.

Analisando o comportamento dos diversos mate riais, tem-se que o componente Piranão vs Demais pelo teste $F$ apresentou valores significativos apenas aos 30 e 75 dias após a semeadura. Observando-se os valores das médias, veri fica-se que a área foliar do Piranão apresenta os menores va lores médios em relação aos demais materiais aos 30 e 75 dias apōs a semeadura.

Analisando o componente Híbridos vs Compostos , verifica-se que os valores de ãrea foliar não apresentaram diferenças significativas aos $30,45,75$ e 90 dias após a se meadura, o que ocorreu aos 60 dias após a semeadura. Observan do as médias, depreende-ṣe que os Compostos apresentam-se com valores médios de área foliar superiores aos dos Híbridos na amostragem aos 60 dias após a semeadura.

Conforme concluíram MILTHORPE \& IVINS (1970) , a produção de grãos em cereais é uma função da eficiência fo tossintētica apōs a floração, a qual poderá ser avaliada atra vés da área foliar total. 
Quadro 5. Valoxes de $F$, coeficientes de variação, média dos materiais e médias dos adubos, para os dados de àrea foliar $\left(\mathrm{dm}^{2}\right)$, nas diversas amostragens.

\begin{tabular}{|c|c|c|c|c|c|c|}
\hline \multirow{2}{*}{$\begin{array}{l}\text { Causas de } \\
\text { Variação }\end{array}$} & \multicolumn{6}{|c|}{ Dias após a Semeadura } \\
\hline & 30 & 45 & 60 & 75 & 90 & 105 \\
\hline Adubos (A) & $1,79^{\text {ns }}$ & $1,47^{\mathrm{ns}}$ & $0.08^{\mathrm{ns}}$ & $0,41^{\mathrm{ns}}$ & $0,28^{n s}$ & $0,56^{\mathrm{ns}}$ \\
\hline Piranäo vs Demais & $4,42^{*}$ & $2,04^{\mathrm{ns}}$ & $2,10^{\mathrm{ns}}$ & $7,53^{*}$ & $0,05^{\text {ns }}$ & - \\
\hline Híbridos vs Compostos & $1,15^{\mathrm{ns}}$ & $0,77^{\text {ns }}$ & $7,46 *$ & $4,03^{\mathrm{nS}}$ & $1,24^{\mathrm{nLS}}$ & - \\
\hline H.D. vs Dina 10 & $1,77^{\mathrm{ns}}$ & $0,07^{n s}$ & $0,00^{\mathrm{ns}}$ & $0,00^{\text {ns }}$ & $0,4_{i} 9^{\mathrm{ns}}$ & - \\
\hline C.F. vs C.D. & $0,50^{\mathrm{ns}}$ & $2,71^{\mathrm{nS}}$ & $0,63^{\mathrm{ns}}$ & $0,60^{\mathrm{ns}}$ & $5,45^{*}$ & - \\
\hline Interação A x M & $1,67^{\mathrm{ns}}$ & $0,41^{\mathrm{ns}}$ & $1,25^{\mathrm{ns}}$ & $0,46^{\mathrm{ns}}$ & $0,20^{\mathrm{ns}}$ & $2,80 *$ \\
\hline V. $\left(\frac{8}{8}\right)$ & 27,50 & 54,48 & 47,85 & 21,50 & 27,85 & 34,46 \\
\hline
\end{tabular}

Médias dos Materiais

\begin{tabular}{lrllllll}
\hline Piranão & 38,90 & 294,95 & 452,68 & 396,55 & 394,30 & - \\
H.D. & 51,64 & 210,77 & 475,31 & 472,54 & 363,12 & - \\
C.F. & 54,60 & 295,25 & 690,58 & 527,14 & 492,20 & - \\
C.D. & 49,94 & 189,06 & 801,14 & 567,86 & 361,25 & - \\
Dina 10 & 42,93 & 193,74 & 480,33 & 473,49 & 402,18 & - \\
\hline
\end{tabular}

Médias dos Adubos

\begin{tabular}{lllllll}
\hline Mineral & 44,82 & 261,50 & 567,78 & 476,87 & 393,24 & 253,11 \\
Orgâni:co & 50,37 & 212,01 & 592,24 & 498,20 & 411,99 & 263,20 \\
\hline
\end{tabular}

$n s=$ não significativo $(P>0,05)$

* = significativo $(P<0,05)$

** = significativo $(P<0,01)$ 
Observando o comportamento dos compostos, veri fica-se, pelo teste $F$, que houve diferenças significativas entre estes materiais apenas aos 90 dias após a semeadura. Pe las médias, pode-se observar que o Composto Flint apresenta valor médio de área foliar superior ao do Composto Dentado aos 90 dias após a semeadura.

Com relação à interação AxM observa-se que não houve diferença significativa em todas as amostragens, com exceção da realizada aos 105 dias após a semeadura. Objetivan do melhor visualizar esta diferença, procedeu-se ao desdobra mento dos graus de liberdade desta interação e os dados es tão apresentados no Quadro 6, no qual observa-se que o compo nente Piranão vs Demais foi significativo quanto à área fo liar dentro do fertilizante mineral, e pela média dos mate riais, verifica-se que o Piranão apresenta o menor valor mé dio $\left(162,16 \mathrm{dm}^{2}\right)$. Alguns autores, como POYE (1973); FIIIPPOV \& VISHNEYSKII ( 1982 ) têm feito considerações sobre a eficiên cia de translocação de materiais pelas plantas braquíticas, comparativamente com as variedades de porte alto, ocorrendo portanto um menor gasto de energia no processo de transloca ção nas plantas braquíticas, onde a fonte e os depōsitos acham-se mais próximos. Com relação ao fertilizante orgânico, o componente Piranão vs Demais não apresenta diferenças sig nificativas pelo teste $F$, embora a média do Piranão, tenha sido a maior $\left(334,53 \mathrm{dm}^{2}\right)$.

Ainda pelo Quadro 6 , dentro do fertilizante mi 
nexal observa-se pelo teste $F$, que os componentes Hibridos vs Compostos, entre os Híbridos e entre os Compostos não apre sentaram diferenças significativas com relação à área foliar. Dentro do fertilizante orgânico, verificam-se

Quadro 6. Valores de $F$ para o desdobramento dos graus de 1 i berdade da interação adubos $x$ materiais ( $A \times M$ ) $e$ médias dos materiais dentro de cada fertilizante, para ārea foliar $\left(\mathrm{dm}^{\hat{2}}\right)$, aos 105 dias.

\begin{tabular}{|c|c|c|}
\hline Causas de & Dentro do Fertili & Dentro do Fertili \\
\hline Variação & lizante Mineral & zante Orgânico \\
\hline Piranão vs Demais & $8,51 * *$ & $2,85^{\mathrm{ns}}$ \\
\hline Híbridos vs Compostos & $1,34^{\mathrm{ns}}$ & $1,43^{\mathrm{ns}}$ \\
\hline H.D. vs Dina 10 & $1,36^{\mathrm{ns}}$ & $4,68^{*}$ \\
\hline C.F. vs C.D. & $0,36^{\mathrm{ns}}$ & $1,13^{\mathrm{ns}}$ \\
\hline \multicolumn{3}{|l|}{ Média dos materiais } \\
\hline Piranão & 162,16 & 334,53 \\
\hline H.D. & 250,07 & 144,80 \\
\hline C.F. & 363,97 & 309,07 \\
\hline C.D. & 323,60 & 238,13 \\
\hline Dina 10 & 327,91 & 289,47 \\
\hline
\end{tabular}

ns = não significativo $(\mathrm{P}>0,05)$

* = significativo $(P<0,05)$

** = significativo $(P<0,01)$ 
diferenças significativas entre os Hîbridos e não significatí vas entre os outros materiais. Pelas médias dos materiais den tro do fertilizante orgânico, depreende-se que o Híbrido Du plo apresenta menor área foliar $\left(144,80 \mathrm{dm}^{2}\right)$ que 0 Híbrido Dina $10\left(289,47 \mathrm{dm}^{2}\right)$.

\subsection{Comprimento do Colmo}

O Quadro 7 refere-se as análises para os valores de comprimento do colmo, onde os valores de $F$ apresentam di ferenças não significativas ao longo de todo o período de amostragem, para o componente Adubos, indicando a sua não in fluência nesta característica.

Analisando o comportamento dos materiais de mi lho, observa-se que o componente Piranão vs Demais apresenta diferenças significativas ao longo de todo o período de amos tragem, e pelas médias dos materiais, observa-se que o Pira não apresenta-se sempre com valores médios inferiores aos de mais materiais, devido à seleção genética ter-lhe conferido as caracteristicas de planta de porte baixo. Alguns pesqui sadores, como BULLOW (1971), PATERNIANI (1980), SOUZA Jr. \& ZINSLY (1981) têm reportado resultados favoráveis dos mate riais braquíticos, em relação a plantas acamadas e/ou quebra das.

Observando o componente Hỉbridos vs Compostos , verifica-se que há diferenças significativas em todas as amos tragens. Analisando as médias destes materiais, observa - se que os Compostos se apresentam sempre com comprimentos do col 
Quadro 7. Valores de $F$, coeficientes de variação, médias dos * materiais e médias dos adubos, para os dados de com primento dos colmos ( $\mathrm{cm})$, nas diversas amostragens.

\begin{tabular}{|c|c|c|c|c|c|}
\hline \multirow{2}{*}{$\begin{array}{l}\text { Causas de } \\
\text { Variação }\end{array}$} & \multicolumn{5}{|c|}{ Dias após a Semeadura } \\
\hline & 45 & 60 & 75 & 90 & 205 \\
\hline Adubos (A) & $1,01^{\mathrm{ns}}$ & $2,14^{\mathrm{ns}}$ & $0,01^{\mathrm{nS}}$ & $0,09^{\mathrm{ns}}$ & $0,15^{\text {ns }}$ \\
\hline Piranão vs Demais & $12,59 * *$ & $38,74^{* *}$ & $66,10 * *$ & $38,94 * *$ & $64,76 * *$ \\
\hline Híbridos vs Compostos & $6,30 *$ & $4,54 *$ & $8,40 * *$ & $4,71 *$ & $25,76 * *$ \\
\hline H.D. vs Dina 10 & $0,98^{\text {ns }}$ & $0,10^{\text {ns }}$ & $0,49^{\mathrm{ns}}$ & $0,04^{\mathrm{ns}}$ & $0,29^{\mathrm{ns}}$ \\
\hline C.F. VS C.D. & $8,19 * *$ & $9,29 * *$ & $0,12^{\text {ns }}$ & $12,86 * *$ & $5,73 *$ \\
\hline Interação A X M & $0,53^{\mathrm{ns}}$ & $1,60^{\text {ns }}$ & $0,03^{\mathrm{ns}}$ & $1,41^{\text {ns }}$ & $1,36^{\mathrm{ns}}$ \\
\hline C.V. 웅 & 44,84 & 18,20 & 10,61 & 11,64 & 8,52 \\
\hline \multicolumn{6}{|l|}{ Médias dos Materiais } \\
\hline Piranäo & 4.88 & 45,17 & 118,63 & 126,08 & 147,12 \\
\hline H.D. & 10,21 & 70,84 & 168,42 & 164,81 & 181,54 \\
\hline C.F. & 16,19 & 91,28 & 184,63 & 197,48 & 222,00 \\
\hline C.D. & 9,88 & 71,75 & 181,65 & 163,32 & 202,84 \\
\hline Dina 10 & 8,02 & 72,88 & 162,37 & 166,73 & 183,83 \\
\hline \multicolumn{6}{|l|}{ Médi as dos Adubos } \\
\hline Mineral & 10,54 & 73,35 & 163,36 & 162,79 & 188,85 \\
\hline Orgânico & 9,13 & 67,42 & 162,92 & 164,59 & 185,89 \\
\hline
\end{tabular}

$\mathrm{ns}=$ não significativo $(\mathrm{P}>0,05)$

* = significativo $(\mathrm{P}<0,05)$

** $=$ significativo $(P<0,01)$ 
mo maiores que os observados nos Híbridos, ou seja, os Compos tos apresentam plantas mais altas que os Híbridos.

Entre os Hîbridos, observa-se que não houve di ferenças significativas entre eles, e analisando o comportá mento dos Compostos, verifica-se que ocorreram diferenças sig nificativas em todas as amostragens, exceto aos 75 dias apōs a semeadura. Da anālise das médias dos materiais depreende-se que o Composto Flint apresenta; de modo geral, valores supe riores aos do Composto Dentado, ao longo de todo o período de amostragem.

Os dados da interação A x M, pelo teste $F$, revelaram nạo apresentar diferenças significativas desta interação, ao longo de todo período de amostragens, para o parâmetro comprimento do colmo.

\subsection{Acumulação da Matéria Seca.}

\subsubsection{Colmo}

O Quadro 8 apresenta as análises dos dados de produção de matéria seca acumulada nos colmos, e pelos valo res de $F$, pode-se observar que não houve diferença significa tiva entre os Adubos para este parâmetro, ao longo de todo o período de amostragem.

Analisando o comportamento dos materiais de mi 1ho, observa-se que o componente Piranão vs Demais, apresenta 
Quadro 8. Valores de F, coeficientes de variação, mëdias dos

" materiais e médias dos adubos, para os dados de produção de matëria seca acumulada nos colmos (g), nas diversas amostragens.

\begin{tabular}{|c|c|c|c|c|c|}
\hline \multirow{2}{*}{$\begin{array}{l}\text { Causas de } \\
\text { Variaçäo }\end{array}$} & \multicolumn{5}{|c|}{ Dias apös a semeadura. } \\
\hline & 45 & 60 & 75 & 90 & 105 \\
\hline Adubos (A) & $0,72^{\text {ns }}$ & $0,06^{\mathrm{ns}}$ & $0,80^{\mathrm{ns}}$ & $0,23^{\mathrm{ns}}$ & $0,00^{\mathrm{ns}}$ \\
\hline Piranão vs Demais & $2,29^{\mathrm{ns}}$ & $7,95 * *$ & $22,03^{* *}$ & $16,32 * *$ & 27,07 \\
\hline Hübridos vs Compostos & $5,31 *$ & $5,13 *$ & $9,49 * *$ & $3,69^{\text {ns }}$ & $19,39 *$ \\
\hline H.D. vs Dina 10 & $0,01^{\mathrm{ns}}$ & $1,22^{\mathrm{nS}}$ & $0,95^{n s i}$ & $3,68^{n s}$ & $3,96^{\mathrm{ns}}$ \\
\hline C.F. vs C.D. & $2,33^{\mathrm{ns}}$ & $3,73^{\text {ns }}$ & $8,65 * *$ & $5,13 *$ & $1,13^{\mathrm{ns}}$ \\
\hline Interação A x M & $0,55^{\text {ns }}$ & $1,71^{\mathrm{ns}}$ & $x, 29^{\mathrm{ns}}$ & $1,23^{\mathrm{ns}}$ & $1,86^{\mathrm{ns}}$ \\
\hline C.V. $(\%)$ & 72,92 & 39,27 & 27,35 & 26,10 & 20,76 \\
\hline \multicolumn{6}{|l|}{ Médias dos Materiais } \\
\hline Piranão & 0,80 & 7,44 & 21,26 & 30,87 & 38,11 \\
\hline $\mathrm{H} . \mathrm{D}$. & 1,00 & 9,41 & 31,71 & 40,27 & 41,99 \\
\hline C.E. & 2,06 & 16,43 & 51,95 & 61,13 & 61,41 \\
\hline C.D. & 1,37 & 12,08 & 37,55 & 47,44 & 67,20 \\
\hline Dina 10 & 0,96 & 11,30 & 36,47 & 51,88 & 52,80 \\
\hline
\end{tabular}

Médias dos Adubos

\begin{tabular}{llllll}
\hline Mineral & 1,36 & 11,63 & 34,40 & 45,40 & 52,31 \\
Orgânico & 1,12 & 11,27 & 37,18 & 47,24 & 52,30 \\
\hline
\end{tabular}

ns $=$ não significativo $(P>0,05)$

$*=$ significativo $(\mathrm{P}<0,05)$

** = significativo $(\mathrm{P}<0,01)$ 
diferenças não significativas aos 45 dias apōs a semeadura e significativas em todas as outras amostragens. Pelas médias dos materiais, depreende-se que o Piranão apresenta, no geral, os menores valores de matéria seca acumulada nos colmos, ao longo de todo o período de amostragem.

Observando o componente Híbridos vs Compostos, verifica-se que não houve diferenças significativas aos 90 dias após a semeadura, o que otorreu nas demais amostragens. Analisando as mëdias destes materiais, verifica-se que os com postos apresentam, no geral, valores médios de acumulação de matéria seca nos colmos, maiores que aqueles observados nos Híbridos, e que a diferença de acumulação foi mais acentuada aos 105 dias após a semeadura, com um valor próximo a 17,0 g. Vărios autores têm apontado que ocorre uma redução significa tiva no peso da matéria seca do colmo, em diversas varieda des de milho, no final do amadurecimento dos grãos (HOYT \& BRADFIELD， 1962) .

Ainda pelo Quadro 8 verifica-se que os Híbridos não apresentaram diferenças significativas, ao longo de todo o período de amostragem, enquanto que o Composto Flint apre sentou maior acúmulo de matéria seca no colmo em relação ao Composto Dentado aos 75 e 90 dias após a semeadura.

Observando a interação A x M, verifica. - se que não houve, pelo teste $F$, diferenças significativas, ao lon go de todo período de amostragens, para esta causa de varia 
ção, dentro do parâmetro produção de matéria seca acumulada nos colmos.

\section{- 4.6.2. Bainha}

O Quadro 9 apresenta as análises dos dados de produção de matēria seca acumulada nas bainhas nas diversas amostragens e, com relação aos Adubos, observa-se que houve diferenças significativas somente aos 30 dias após a semeadu ra. Pela média dos adubos pode-se verificar que o orgânico apresenta valor médio maior $(0,86$ g) que o mineral $(0,64$ g), aos 30 dias após a semeadura.

Com relação aos diversos materiais de milho, o componente Piranão vs Demais, apresentou diferenças signifi cativas apenas aos 30 dias após a semeadura. O exame das mé dias destes materiais mostra que o Piranão apresentou, nesta amostragem, o menor valor $(0,52 \mathrm{~g})$ em relação aos Demais $(0,72 \mathrm{~g})$.

Para o componente Híbridos vs Compostos, veri ficam-se diferenças significativas apenas aos 30, 45 e 105 dias após a semeadura. Observando as médias destes materiais depreende-se que os Compostos apresentam, nestas amostragens, valores médios superiores de acumulação de matéria seca nas bainhas do que os apresentados pelos Híbridos.

Dentre os Compostos, verificam-se diferenças significativas aos 30 e 90 dias após a semeadura, com o Com 
posto Flint apresentando valores superiores ao do Composto Dentado. Sabe--se que as bainhas são as vias de transporte do material para o resto da planta, assim como órgãos de susten tação das lâminas foliares e, observando-se os valores médios dos materiais no final do ciclo da cultura (105 dias), tem-se que os não compostos apresentaram os valores mais elevados na acumulação de matêria seca nas bainhas.

Para a interação $\mathbb{A} \times$ M verifica-se significân cia aos 60 diasi após a semeadura. Objetivando esclarecer esta interação, efetuou-se o desdobramento dos graus de liberdade, apresentado no Quadro 10, no qual observa-se que dentro do adu् bo mineral não houve diferença significativa para nenhum dos componentes estudados, ao passo que, dentro do fertilizante orgânico constatam-se diferenças significativas para os com ponentes Piranão vs Demais; entre os Híbridos e entre os Com postos. Pelas médias dos materiais, dentro do fertilizante or gânico, verifica-se que houve maior acúmulo de matéria seca nas bainhas aos 60 dias após a semeadura para o Composto Flint $(11,34 \mathrm{~g})$ e o menor para o Piranão $(3,40 \mathrm{~g})$. 
Quadro 9. Valores de $F$, coeficientes de variação, médias dos materiais e médjas dos adubos, para os dados de pro dução de matêria seca acumulada nas bainhas ( $g$ ), nas diversas amostragens.

\begin{tabular}{lcccccc}
\hline Causas de & \multicolumn{5}{c}{ Dias após a semeadưra } \\
\cline { 2 - 6 } Variaço & 30 & 45 & 60 & 75 & 90 & 105 \\
\hline Adubos (A) & $10,55^{* *}$ & $1,16^{\mathrm{ns}}$ & $0,70^{\mathrm{ns}}$ & $0,23^{\mathrm{ns}}$ & $0,15^{\mathrm{ns}}$ & $0,19^{\mathrm{ns}}$ \\
piranão vs Demais & $10,95^{* *}$ & $0,02^{\mathrm{ns}}$ & - & $0,05^{\mathrm{ns}}$ & $0,12^{\mathrm{ns}}$ & $2,71^{\mathrm{ns}}$ \\
Híbridos vs Compos tos & $4,67^{*}$ & $5,00^{*}$ & - & $0,61^{\mathrm{ns}}$ & $1,65^{\mathrm{ns}}$ & $7,34^{*}$ \\
H.D. vs Dina 10 & $3,14^{\mathrm{ns}}$ & $0,09^{\mathrm{ns}}$ & - & $1,31^{\mathrm{ns}}$ & $3,07^{\mathrm{ns}}$ & $0,15^{\mathrm{ns}}$ \\
C.F. vs C.D. & $4,23^{*}$ & $3,28^{\mathrm{ns}}$ & - & $0,02^{\mathrm{ns}}$ & $4,35^{*}$ & $0,52^{\mathrm{ns}}$ \\
Interação A $\times \mathrm{m}$ & $2,32^{\mathrm{ns}}$ & $0,47^{\mathrm{ns}}$ & $2,95^{*}$ & $0,85^{\mathrm{ns}}$ & $0,16^{\mathrm{ns}}$ & $0,58^{\mathrm{ns}}$ \\
\hline C.V. (8) & 29,28 & 42,42 & 34,74 & 27,77 & 30,39 & 25,02 \\
\hline
\end{tabular}

Médias dos Materiais

\begin{tabular}{lllllll}
\hline Piranão & 0,52 & 2,84 & - & 15,65 & 14,82 & 17,38 \\
H.D. & 0,82 & 2,54 & - & 14,14 & 12,37 & 12,66 \\
C.F. & 1,00 & 3,99 & - & 16,50 & 18,95 & 16,02 \\
C.D. & 0,78 & 2,87 & - & 16,80 & 14,09 & 17,41 \\
Dina 10 & 0,63 & 2,36 & - & 16,70 & 16,45 & 13,40 \\
\hline Médias dos Adubos & & & & & & \\
\hline Mineral & 0,64 & 3,14 & 6,80 & 15,62 & 15,05 & 15,64 \\
Orgânico & 0,86 & 2,71 & 7,46 & 16,30 & 15,62 & 15,10 \\
\hline
\end{tabular}

$\mathrm{ns}=\mathrm{não}$ significativo $(\mathrm{p}>0,05)$

* = significativo $(\mathrm{P}<0,05)$

$* *$ = significativo $(\mathrm{P}<0,01)$ 
Quadro 10. Valores de F para o desdobramento dos graus de libex dade da interação adubos $x$ materiais $(A \times M)$ e mé dias dos materiais dentro de cada fertilizante, para a prođução de matéria seca acumulada nas bainhas (g), aos 60 dias.

Causas de

Variação

Piranão vs Demais

Híbridos vs Compostos

H.D. vs Dina 10

C:F. vs C.D.
Dentro do Fertili Dentro do Fertili zante Mineral zante Orgänico

$4.07^{\mathrm{ns}}$

$13,46 * *$

$0,64^{\text {ns }}$

$0,59^{\text {ns }}$

$0,99^{\text {ns }}$

$9,68 * *$

$0.54^{\text {ns }}$

Médias dos Materiais

Piranão

4,57

3,40

H. D.

7,73

5,28

C.F.

8,50

11,34

C. D.

7,21

6,56

Dina 10

5,99

10,73

ns $=$ não significativo $(P>0,05)$

* $\quad=$ significativo $(P<0,05)$

$* *$ = significativo $(P<0,01)$ 


\subsubsection{Lâminas Foliares}

- Quadro 11 apresenta as análises dos dados de produção de matéria seca acumulada nas folhas $(g)$ nas diversas amostragens. Observando os valores de $\mathrm{F}$ com relação aos Adu bos, verifica-se que são não significativos, ao longo de todo o período de amostragem, indicando que os fertilizantes não Influem neste parâmetro.

Ainda com relação aos valores de F, observa - se. que o componente Piranão vs Demais apresenta-se significativo, somente aos 60 dias após a semeadura. Pelas médias dos mate riais, observa-se que, nesta amostragem o Piranão apresentou acúnulo de matéria seca nas lâminas foliares inferior ao dos Demais.

Para o componente Híbridos vs Compostos; verifí ca-se diferença significativa apenas aos 60 dias apōs a semea dura, com os Compostos apresentando, em média, maior àcúmulo dẹ matéria seca nas folhas que os Híbridos, que apresentaram acūrnulos semelhantes.

Observando o comportamento dos Compostos, veri ficam-se diferenças significativas aos 45, 60 e 90 dias após a semeadura. Analisando as médias destes materiais, observa-- se que o Composto Flint apresenta, nessas amostragens acúmulo de matéria seca nas folhas superior ao do Composto Dentado.

A interação A X M mostrou-se significativa aos 105 dias apōs a semeadura. Procurando melhor analisar o compor 
Quadro 11. Valores de $F$, coeficientes de variaçäo, médias dos materiais e médias los adubos, para os dados de pro duçäo da matéría seca acumulada nas folhas (g), nas diversas amostragens.

\begin{tabular}{|c|c|c|c|c|c|c|}
\hline \multirow{2}{*}{$\begin{array}{l}\text { Causas de } \\
\text { Variação }\end{array}$} & \multicolumn{6}{|c|}{ Dias após a Semeadura } \\
\hline & 30 & 45 & 60 & 75 & 90 & 205 \\
\hline Adubos $(A)$ & $3,25^{\mathrm{ns}}$ & $0,54^{\mathrm{ns}}$ & $0,10^{125}$ & $0,52^{n S}$ & $0,05^{\mathrm{ns}}$ & $0,30^{n s}$ \\
\hline Piranão vs Demais & $3,17^{n S}$ & $2,07^{\mathrm{nS}}$ & $5,72 *$ & $2,42^{n s}$ & $3,03^{n .5}$ & - \\
\hline Híbridos vs Compostos & $4,01^{\mathrm{nS}}$ & $3,03^{n s}$ & $9,75 * *$ & $2,89^{\mathrm{nS}}$ & $1,65^{\mathrm{nS}}$ & - \\
\hline H.D. vs Dina 20 & $2,47^{\mathrm{NS}}$ & $0,21^{\mathrm{ns}}$ & $2,94^{\mathrm{ns}}$ & $0,44^{\mathrm{ns}}$ & $0,07^{n s}$ & - \\
\hline C.F. vs. C.D. & $3,04^{\mathrm{nS}}$ & $5,34 *$ & $5,46 *$ & $0,52^{n s}$ & $6,87 \star$ & - \\
\hline Interą̧ão A $\times M$. & $0,93^{\mathrm{ns}}$ & $0,97^{\text {ns }}$ & $0,73^{n s}$ & $1,18^{n 5}$ & $0,18^{n s}$ & $3,60 x * x$ \\
\hline
\end{tabular}

Médias dos Materiais

\begin{tabular}{lrrrrrl}
\hline Piranäo & 1,98 & 7,02 & 17,66 & 20,62 & 23,35 & - \\
H.D. & 2,43 & 7,57 & 17,50 & 20,65 & 24,30 & - \\
C.F. & 3,00 & 10,31 & 26,28 & 24,40 & 34,77 & - \\
C.D. & 2,40 & 7,38 & 21,44 & 26,66 & 23,11 & - \\
Dina.10 & 2,01 & 6,70 & 21,05 & 22,75 & 25,50 & - \\
\hline
\end{tabular}

Médias dos Adubos

\begin{tabular}{lllllll}
\hline Mineral & 2,17 & 8,15 & 20,99 & 22,29 & 26,50 & 24,31 \\
Orgânico & 2,56 & 7,56 & 20,59 & 23,74 & 25,90 & 23,46 \\
\hline
\end{tabular}

ns = não significativo $(P>0,05)$

* = significativo $(\mathrm{p}<0,05)$

$\star \star=$ significativo $(P<0,01)$ 
tamento dos diversos materiais de milho em relaçāo aos ferti Iizantes utilizados, fez-se o desdobramento dos graus de liber dade desta interação, apresentado no Quadro 12, de cuja anäli se pode-șe verificar que ocorreram,dentro do fertilizante mineral, di ferenças significativas para os componentes Piranão vs Demais e Híbridos vs Compostos, com o Piranão apresentando o menor acü mulo de matéria seca nas folhas $(17,85 \mathrm{~g})$ e os Compostos o maior valor $(29,40 \mathrm{~g})$, ambos aos 105 dias apōs a . semeadura. Quando da anālise do peso seco das folhas e produção de grãos em milho, HANWAY (1962) constatou que estes fatores acham - se primeiramente influenciados pelo peso de folhas por planta. Ressaltam TANAKA e YAMAGUCHI (1972) que o entendimento dos processos de acumulação da matéria seca e de carboidrato, nos diferentes ór gãos da planta, é um pré-requisi.to para o aperfeiçoamento das práá ticas culturais.

Ainda, com relação ao Quadro 12 , observa - se que, dentro do fertilizante orgânico, houve diferença significativa apenas entre os Híbridos, sendo que o Dina 10 apresenta acū mulo de matéria seca nas folhas superior ao do Híbrido Duplo. 
Quadro 12. Valores de F para o desdobramento dos graus de $1 \underline{1}$ berdade da interação adubos $x$ materiats (A X M) e médias dos materiats dentro de cada fertilizante. para a produção de matériz seca acumulada nas fo thas $(g)$, aos 105 dias.

Causas de

Variação Piranão vs Demais

Híbridos vs compostos

H.D. vs Dina 10

C.F. vs C.D.

Médias dos Matexiais
Dentro do Fertili Dentro do Fertili zante Mineral zante orgânico

$1,86^{\text {ns }}$

$8,81 * *$

$8,13 * *$

$3,01^{\text {ns }}$

$0,41^{\text {ns }}$ $0,88^{\mathrm{ns}}$

$7,52 *$

$2,76^{\text {ns }}$

Piranão 17,85

26,44

H.D.

19,47

16,86

C.F.

28,29

26,73

C.D.

30,50

21,00

Dina 10

25,44

26,30

ns = não significativo $(P>0,05)$

* = significativo $(P<0,05)$

$* *$ = significativo $(P<0,01)$ 


\subsubsection{Inflorescência Masculina}

O Quadro 13 apresenta as análises dos dados da produção de matéria seca acumulada nos pendões (g) nas diver . sas amostragens; verificando-se que os adubos não influem no acúmulo de matéria seca nos pendões ao longo de todo o perío do de amostragem.

O componente Piranão vs Demais apresenta-se sig nificativo em todas as amostragens, com o Piranão acumulando sempre teores inferiores de matéria seca nos pendões.

O componente Híbridos vs compostos, também apre senta-se significativo em todas as amostragens, constatando-se que os Compostos apresentam ao longo de todo o período de amos tragem, maior acúmulo de matéria seca nos pendões que aqueles observados nos Híbridos.

Com relação aos Híbridos, os valores do teste $F$ apresentam diferenças não significativas, ao longo de todio 0 período de amostragens.

Observando o comportamento dos Compostos, pelos valores de $F$, verifica-se que houve diferenças significativas, quanto ao parâmetro acumulação de matéria seca nos pendões, aos 90 dias, e não significativas aos 75 e 105 dias após a semeadura. Fela análise das méaias dos cultivares observa - se que aos 90 dias, o Composto Flint aparece com valor médio superior ao do Composto Dentado.

Com relação à interação AxM; observa-se que os va- 
Quadro 1,3. Valores de F, ceeftcientes de variaçäo, médias dos materiais e médias dos adubos, para os dados da produção da matéxía seca acurnulada nos pendões ( $g$ ), nas diversas amostragens.

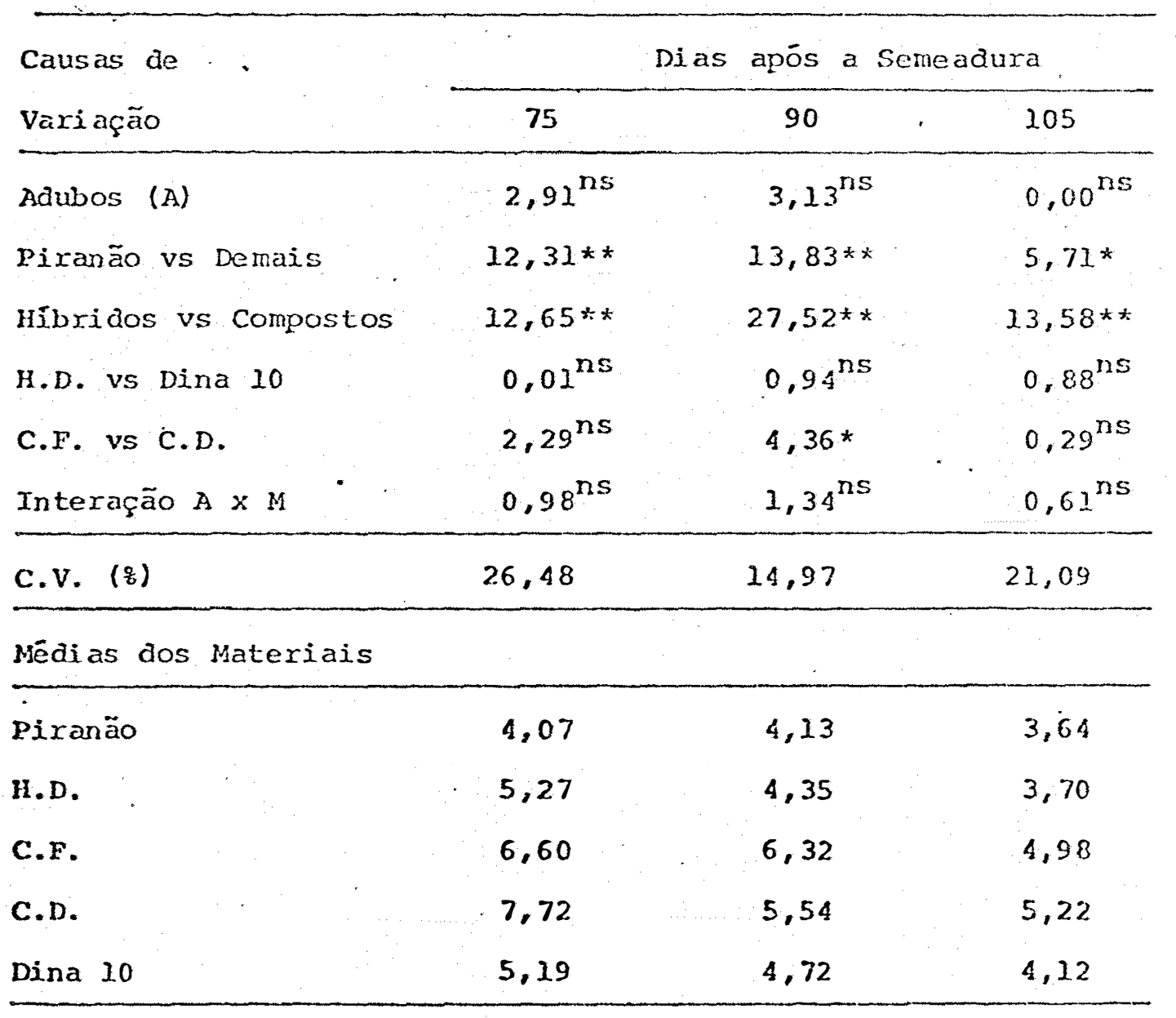

Médias das Adubos

\begin{tabular}{llll}
\hline Mineral & 6,18 & 5,22 & 4,33 \\
Orgânico & 5,35 & 4,80 & 4,32 \\
\hline
\end{tabular}

ns $=$ não significativo $(P>0,05)$

* = significativo $(P<0,05)$

$* *=$ significativo $(P<0,01)$ 
lores de F, apresentam-se com diferenças não significativas ao longo de todo período de amostragens, para o parâmetro acumulação de matéria seca nos pendões.

\subsubsection{Inflores cência Feminina}

O Quadro 14, reporta as análises dos dados de produção de matéria seca acumulada nas espigas (g), nas diver sas amostragens, observando-se que os Adubos não influem no acúmulo de matéria seca nas espigas, ao longo de toảo o perioo do de amostragem.

Analisando o comportamento dos diversos mate riais de milho estudados, verifica-se que as diferenças ao lon go de todo o período de amostragens não foram significativas para todos os componentes, indicando uma certa uniformidade dos materiais no acúmulo de matéria seca nas espigas.

\subsubsection{Acumulação de Matéxia Seca Total}

Através do Quadro 15, que mostra as análises dos dados de peso seca de matéria seca total ( $\mathrm{g} / \mathrm{planta),} \mathrm{acumulado}$ nas diversas amostragens, observa-se que as diferenças foram não significativas, para os Adubos, ao longo de toto o periodo de amostragem com relação ao peso seco total das plantas, indicando que o tipo de adubo não influi neste parâmetro.

Analisando o comportamento dos diversos culti- 
Quadra 14. Valores de $F$, coeficientes de variação, médias dos materiais e médias dos adubos para os dados da pro dução da matéria seca acumulada nas espigas ( $g$ ), nas diversas amostragens.

\begin{tabular}{|c|c|c|c|}
\hline Causas de & Dias Após & & \\
\hline Variação & 30 & 60 & 75 \\
\hline Adubos (A) & $0.25^{\mathrm{ns}}$ & $0.12^{n s}$ & $0,26^{\mathrm{ns}}$ \\
\hline Pixanão vs Demais & $0,04^{\mathrm{ns}}$ & $0,03^{\mathrm{ns}}$ & $0,22^{\mathrm{ns}}$ \\
\hline Híbridos vs Compostos & $0,13^{\mathrm{ns}}$ & $1,88^{\text {ns }}$ & $1,11^{\text {ns }}$ \\
\hline H.D. Vs Dina 10 & $1,55^{\mathrm{ns}}$ & $1,96^{\mathrm{ns}}$ & $0,01^{\mathrm{ns}}$ \\
\hline C.F. vs C.D. & $0,72^{\mathrm{ns}}$ & $0,89^{\text {ns }}$ & $1,42^{\mathrm{ns}}$ \\
\hline Interação $A \times M$ & $2.09^{\mathrm{ns}}$ & $0.23^{\mathrm{ns}}$ & $0,50^{\mathrm{ns}}$ \\
\hline C.V. (\%) & 52,51 & 39,42 & 23,84 \\
\hline
\end{tabular}

Médias dos Materiais

\begin{tabular}{llll}
\hline Piranão & 14,16 & 58,17 & 122,73 \\
H.D. & 11,83 & 54,14 & 121,89 \\
C.F. & 11,62 & 56,39 & 103,77 \\
C.D. & 14,68 & 45,83 & 120,63 \\
Dina 10 & 16,31 & 69,82 & 123,60 \\
\hline Médias dos Adubos & & & \\
\hline Mineral & 14,29 & 55,62 & 120,80 \\
Orgãnico & 13,14 & 58,11 & 116,26 \\
\hline
\end{tabular}

ns = não significativo $(P>0,05)$ 
Quadro 15. Valores de $F$, coeficientes de variação, médias dos materiais e médias dos adubos, para os dados de pe so de matéria seca total ( $\mathrm{g} / \mathrm{planta})$, acumulada nas diversas amostragens.

\begin{tabular}{|c|c|c|c|c|c|c|}
\hline \multirow{2}{*}{$\begin{array}{l}\text { Causas de } \\
\text { Variação }\end{array}$} & \multicolumn{6}{|c|}{ Dias apōs a Semeadura } \\
\hline & 30 & 45 & 60 & 75 & 90 & 105 \\
\hline Adubos (A) & $3,00^{\mathrm{ns}}$ & $0,84^{\mathrm{ns}}$ & $0,00^{\mathrm{ns}}$ & $0,16^{\mathrm{ns}}$ & $0,06^{\mathrm{ns}}$ & $0,21^{\text {ns }}$ \\
\hline Piranão vs Demais & $5,28 *$ & $0,92^{\text {ns }}$ & $9,38 * *$ & $6,26 *$ & $1,90^{\text {ns }}$ & $0,65^{\mathrm{nS}}$ \\
\hline Híbridos vs Compostos & $2,56^{\mathrm{ns}}$ & $4,60 *$ & $5,73^{*}$ & $4,10^{\mathrm{ns}}$ & $0,08^{\text {ns }}$ & $1,20^{\text {ns }}$ \\
\hline H.D. vs Dina 10 & $3,61^{\mathrm{ns}}$ & $0,14^{\mathrm{ns}}$ & $2,34^{\mathrm{ns}}$ & $1,10^{\mathrm{ns}}$ & $2,52^{\text {ns }}$ & $1,09^{\mathrm{ns}}$ \\
\hline$C . F \cdot$ vs C.D. & $3,13^{\mathrm{ns}}$ & $4,82 *$ & $5,51 *$ & $0,43^{\mathrm{ns}}$ & $3,74^{\mathrm{nS}}$ & $1,21^{\mathrm{ns}}$ \\
\hline Interação $\mathrm{A} \times \mathrm{M}$ & $1,85^{\text {ns }}$ & $0,50^{\mathrm{ns}}$ & $1,85^{\mathrm{ns}}$ & $2,09^{\mathrm{ns}}$ & $0,24^{\mathrm{ns}}$ & $1,12^{\mathrm{ns}}$ \\
\hline C.V. (z) & 29,09 & 35,97 & 26,01 & $24 ; 77$ & 27,76 & 19,09 \\
\hline
\end{tabular}

Médias dos Materiais

\begin{tabular}{lllllll}
\hline Piranão & 2,50 & 10,71 & 31,30 & 75,77 & 131,35 & 204,02 \\
H.D. & 3,52 & 11,11 & 35,72 & 83,60 & 135,43 & 198,40 \\
C.F. & 4,01 & 16,37 & 55,42 & 111,03 & 176,13 & 213,69 \\
C.D. & 3,19 & 11,62 & 42,76 & 103,41 & 136,01 & 236,21 \\
Dina 10 & 2,64 & 10,31 & 44,04 & 97,43 & 168,37 & 219,80 \\
\hline
\end{tabular}

Média dos Adubos

\begin{tabular}{lllllll}
\hline Mineral & 2,92 & 12,65 & 41,90 & 92,79 & 147,80 & 217,39 \\
Orgânico & 3,43 & 11,40 & 41,79 & 95,71 & 151,12 & 211,46 \\
\hline
\end{tabular}

ns $=$ não significativo $(P>0,05)$

* = significativo $(P<0,05)$

** = significativo $(\mathrm{P}<0,01)$ 
vares de milho, observarse que, com relação ao componente Piranão vs Demais, as diferenças foram significativas aos 30, 60 e 75 dias após a semeadura, com o Piranão apresentando, nes sas amostragens, valores menores que aqueles observados entre os demais.

Para o componente Híbridos vs Compostos, verifi ca-se que as diferenças foram significativas apenas aos 60 dias após a semeadura, com os Compostos apresentando peso de ma téria seca total maiores çue aqueles auferidos para os Híbridos, resulta dos estes, concordantes com DIAZ \& RIVERA (1978); CROSBIE \& MO CK (1981), os quais observaram que os milhos melhorados, do grupo tardio, apresentaram maior peso de matéria seca.

Analisando o comportamento dos Híbridos, observa -se que, os valores de F, apresentam diferenças não significą tivas ao longo de todo o período de amostragens, com relação ao parâmetro peso de matéria seca total.

Pela análise do comportamento dos Compostos, ve rifica-se que as diferenças foram significativas somente aos 45 e 60 dias após a semeadura, sendo os maiores pesos de matéria seca conseguidos pelo Composto Flint.

Observando a interação A x M verifica-se, 'atra vés dos valores de $F$, que as diferenças foram não significatí vas ao longo de todo período de amostragens. 


\subsection{Análise Química das Folhas}

o objetivo primordial da análise química foliar è detectar os teores de elementos presentes nas folhas e, a partir destes, diagnosticar o estado nutricional da cultura . Alēm de oferecer um ótimo ponto de referência quanto aó estado nutricional da cultura, auxilia sobremaneira a interpretação dos efeitos da adubação já efetuada, além de colaborar indí retamente, inferindo quanto ao grau de fertilidade do solo.

Segundo TRANI et alii (1983), existem diversas culturas, entre elas a cana, o milho, o café etc., cujos teo res minimos (níveis críticos) jā se acham estabelecidos, razão pela qual, nesse caso, é suficiente retirar-se apenas uma. amos tra da gleba.

O Quadro 16 apresenta os teores mínimos adequados para a cultura do milho cultivada em São Paulo, segundo TRANI et alii (1983), relativa aos macronutrientes.

Quadro 16. Teores mínimos adequados (Níveis Críticos) dos macro nutrientes para a cultura do milho cultivada em são Paulo (TRANI et alii, 1983).

$\begin{array}{lcccccc}\text { Elementos } & \mathrm{N} & \mathrm{P} & \mathrm{K} & \mathrm{Ca} & \mathrm{Mg} & \mathrm{S} \\ & 3,00 & 0,22 & 2,00 & 0,45 & 0,25 & 0,20\end{array}$


o teor mínimo adequado ou "nível crítico" indi ca o teor de nutriente na folha abaixo do qual o suprimento de um nutriente é inadequado e a produção é afetada. Deve - se mencionar que existem materiais genéticos mais exigentes em nutrientes e, consequentemente, os teores acima desses mínimos nem sempre representam excessos.

Existem, atualmente, poucos trabalhos que repor tam os teores máximos de nutrientes, porém o teor de manganēs nas folhas de diferentes culturas não deve apresentar-se acima de 400 ppm, o boro acima de 150 ppm e o de cobre não deve pas sar de $100 \mathrm{ppm}$.

\subsubsection{Macronutrientes}

O Quadro 17 apresenta as anālises dos teores mé dios dos macronutrientes presentes nas folhas aos 70 dias após a semeadura, observando-se que não houve diferenças significa tivas para os Adubos, no que se refere aos teores de $\mathrm{K} \mathrm{e} \mathrm{Ca}$ e ocorrem diferenças significativas entre ele para $\circ \mathrm{N}, \mathrm{P}$ e Mg, com relação aos adubos utilizados.

Analisando o componente Piranão vs Demais, verí fica-se diferença significativa para o teor de $\mathrm{N}$ e não signi ficativas para $\circ \mathrm{K}$ e $\mathrm{Ca}$, observando-se que o Piranão aparece com o maior teor de $\mathrm{N}$, aos 70 dias após a semeadura.

Para o componente Híbridos vs Compostos, verifi ca-se que houve diferença significativa com relação aos teores 
Quadro 17. Valores de $F$, coeficientes de variação, médias dos materiais e médias dos adubos para os teores mé dios dos macronutrientes (\%) presentes nas folhas aos 70 dias.

\begin{tabular}{|c|c|c|c|c|c|}
\hline \multirow{2}{*}{$\begin{array}{l}\text { Causas de } \\
\text { Vari ação }\end{array}$} & \multicolumn{5}{|c|}{ Elementos } \\
\hline & $\mathrm{N}$ & $\mathbf{P}$ & K & $\mathrm{Ca}$ & $\mathrm{Mg}$ \\
\hline Adubos (A) & $26,11 * *$ & $18,52 * *$ & $2,13^{\text {ns }}$ & $0,06^{\mathrm{ns}}$ & $12,03 *$ \\
\hline Piranão vs Demais & $6,00 *$ & - & $0,12^{\mathrm{ns}}$ & $0,41^{\mathrm{ns}}$ & - \\
\hline Híbridos vs Compostos & $12,21 * *$ & - & $1,26^{\text {ns }}$ & $0,84^{\mathrm{ns}}$ & - \\
\hline H.D. vs Dina 10 & $0,03^{\text {ns }}$ & - & $1,58^{\text {ns }}$ & $0,03^{\mathrm{ns}}$ & - \\
\hline C.F. vs C.D. & $5,42 *$ & - & $0,74^{\mathrm{nS}}$ & $0,28^{\text {ns }}$ & - \\
\hline Interação $A \times M$ & $1,69^{\mathrm{ns}}$ & $3,05 *$ & $0,55^{\mathrm{ns}}$ & $1,63^{\text {ns }}$ & $2,85^{*}$ \\
\hline C.V. 8 & 7,52 & 5,64 & 21,17 & 17,92 & 12,57 \\
\hline \multicolumn{6}{|l|}{ Médias dos Materiais } \\
\hline Piranão & 3,08 & - & 3,27 & 0,43 & - \\
\hline H.D. & 3,00 & - & 3,28 & 0,43 & - \\
\hline C.F. & 2,60 & - & 3,17 & 0,42 & - \\
\hline C.D. & 2,86 & - & 3,32 & 0,40 & - \\
\hline Dina 10 & 3,01 & - & 3,50 & 0,43 & - \\
\hline
\end{tabular}

Médias dos Adubos

\begin{tabular}{llllll}
\hline Mineral & 3,08 & 0,25 & 3,22 & 0,42 & 0,16 \\
Orgânico & 2,73 & 0,24 & 3,39 & 0,42 & 0,18 \\
\hline
\end{tabular}

ns = não significativo $(P>0,05)$

* = significativo $(P<0,05)$

** $=$ significativo $(P<0,01)$ 
de $\mathrm{N}$ e não significativas em relação aos de $\mathrm{K}$ e Ca. Observa-se que os Híbridos apresentam teores de $\mathrm{N}$, maiores que aqueles au feridos para os Compostos.

Com relação aos Híbridos, não se constatam dife renças significativas com relação aos teores de $\mathrm{N}, \mathrm{K}$ e Ca.

Observando o comportamento dos Compostos, verifi ca-se que as diferenças foram não significativas para os teo res de $\mathrm{K}$ e Ca e significativas para o teor de $\mathrm{N}$, que é supe rior no Composto Dentado.

Para os teores de $\mathrm{P}$ e $\mathrm{Mg}$, a interação $\mathrm{A} \times \mathrm{M}$ foi significativa e, procurando melhor analisar o comportamento desta interação, realizou-se o desdobramento dos seus graus de liberdade, apresentado no Quadro 18. Analisando-o observa- se que o componente Piranão vs Demais apresenta efeito significa tivo apenas para o teor de Mg, dentro do fertilizante orgâni co, com o Piranão apresentando menor teor.

Para o componente Híbridos vs Compostos, obser va-se que os teores de $\mathrm{P}$ apresentam diferenças significativas tanto dentro do fertilizante mineral como do orgânico, com os Híbridos apresentando teores superiores aos dos Compostos.Para os teores de Mg estas diferenças foram não significativas no caso do fertilizante mineral e significativas dentro do ferti lizante orgânico, sendo superiores os teores apresentados pe los Híbridos.

Analisando o comportamento dos Híbridos, verifi ca-se que as diferenças foram não significativas para o Mg, in 
Quadro 18. Valores de $F$ para o desdobramento dos graus de li berdade da interação adubos $x$ materiais $(A \times M)$ e médias dos materiais dentro de cada fertilizante,pa ra os macronutrientes $\mathrm{P}$ e $\mathrm{Mg}\left(\frac{\circ}{6}\right)$, aos 70 dias.

\begin{tabular}{|c|c|c|c|c|}
\hline \multirow[t]{2}{*}{$\begin{array}{l}\text { Causas de } \\
\text { Variação }\end{array}$} & $\begin{array}{l}\text { Dentro do } \\
\text { zante }\end{array}$ & $\begin{array}{l}\text { Fertili } \\
\text { Mineral }\end{array}$ & $\begin{array}{l}\text { Dentro } \\
\text { zante }\end{array}$ & $\begin{array}{l}\text { do Fertili } \\
\text { Orgânico }\end{array}$ \\
\hline & $\mathrm{P}$ & $\mathrm{Mg}$ & $\mathrm{P}$ & $\mathrm{Mg}$ \\
\hline Piranão vs Demais & $0,65^{\mathrm{ns}}$ & $0,00^{\mathrm{ns}}$ & $3,99^{\mathrm{ns}}$ & $4,61 *$ \\
\hline Híbridos vs Compostos & $8,65 * *$ & $0,12^{\mathrm{ns}}$ & $8,04 * *$ & $7,52 *$ \\
\hline H.D. vs Dina 10 & $3,44^{\mathrm{ns}}$ & $0,10^{\mathrm{ns}}$ & $4,86 *$ & $0,23^{\mathrm{ns}}$ \\
\hline C.F. Vs C.D. & $0,81^{\mathrm{ns}}$ & $5,87 *$ & $0,64^{\mathrm{ns}}$ & $0,23^{\text {ns }}$ \\
\hline
\end{tabular}

Médias dos Materiais

\begin{tabular}{lllll}
\hline Piranão & 0,25 & 0,16 & 0,25 & 0,16 \\
H.D. & 0,28 & 0,16 & 0,24 & 0,21 \\
C.F. & 0,24 & 0,18 & 0,22 & 0,17 \\
C.D. & 0,25 & 0,15 & 0,23 & 0,18 \\
Dina 10 & 0,26 & 0,15 & 0,26 & 0,20
\end{tabular}

ns $=$ não significativo $(P>0,05)$

* = significativo $(P<0,05)$

** = significativo $(\mathrm{P}<0,01)$ 
dependentemente do tipo de fertilizante e, para $O \mathrm{P}$ dentro do fertilizante mineral. Para os teores de P, dentro do fertili zante orgânico, observa-se que houve diferença significativa, sendo o teor do Dina 10 superior ao do Híbrido Duplo.

Com relação ao comportamento dos compostos, ob serva-se que as diferenças foram não significativas para os teores de P, independentemente do tipo de fertilizante e, quan to aos teores de Mg verifica-se que as diferenças foram signi ficativas apenas dentro do fertilizante mineral, com superio ridade do Composto Flint.

Acham-se expostos no Quadro19 os resultados dos teores de macronutrientes presentes nas folhas dos vários cul tivares aos 70 dias após a semeadura, assim como aqueles pro postos por TRANI et alii (1983).

Analisando os valores apresentandos no Quadro 19, observa-se que dentre os diversos materiais estudados, os Compostos apresentam teores de $\mathrm{N}$ presentes nas folhas aos 70 dias, inferiores àqueles observados nos demais materiais, assim como, aos teores mínimos adequados.

Observando-se as médias dos fertilizantes em re lação aos teores de macronutrientes nas folhas, 70 dias após a semeadura, verifica-se, com relação ao teor de $N$, que o valor médio deste elemento com base no fertilizante orgânico é inferior $(2,73)$, ao do fertilizante mineral $(3,08)$, assim como ao teor minimo adequado proposto por TKANI et alii (1983), que é de 3,00. Esta situação talvez advenha do fato da aplicação do 
Quadro 19. Comparação dos teores de macronutrientes em \%, pre sentes nas folhas, aos 70 dias apōs a semeadura, com os teores mínimos adequados propostos por TRANI et alii (1983), para a cultura do milho cultivada no ES tado de são Paulo.

\begin{tabular}{lccccc}
\hline $\begin{array}{l}\text { Elementos } \\
\text { Teores mínimos adequados }\end{array}$ & $\mathrm{N}$ & $\mathrm{P}$ & $\mathrm{K}$ & $\mathrm{Ca}$ & $\mathrm{Mg}$ \\
& 3,00 & 0,22 & 2,00 & 0,45 & 0,25 \\
& & & & & \\
Materiais & Médias dos Materiai.s & & \\
Piranão & 3,08 & 0,25 & 3,27 & 0,43 & 0,16 \\
Híbrido Duplo & 3,00 & 0,26 & 3,28 & 0,43 & 0,24 \\
Composto Flint & 2,60 & 0,23 & 3,17 & 0,42 & 0,20 \\
Composto Dentado & 2,86 & 0,24 & 3,32 & 0,40 & 0,21 \\
Dina 10 & 3,01 & 0,26 & 3,50 & 0,43 & 0,23
\end{tabular}

Médias dos Fertilizantes

Mineral

$3,08 \quad 0,25 \quad 3,22 \quad 0,42 \quad 0,16$

Orgânico

$2,73 \quad 0,24 \quad 3,39 \quad 0,42 \quad 0,18$ 
fertilizante orgânico ter sido feita de uma só vez, antes da semeadura, adequando a quantidade de $60 \mathrm{~kg} / \mathrm{ha}$ de $\mathrm{N}$, enquanto que a aplicação do fertilizante mineral foi realizada em duas etapas, ou seja, $10 \mathrm{~kg} / \mathrm{ha}$ de $\mathrm{N}$ na semeddura e $50 \mathrm{~kg} / \mathrm{ha}$ de $\mathrm{N}$ em cobertura. Pelo exposto, pode-se supor que o elemento presente no fertilizante orgânico, teve um tempo maior que aquele do fertilizante mineral para sofrer o processo de lixiviação.

No caso do fósforo, observa-se que os teores des te elemento nas folhas dos diversos materiais de milho foram, de modo geral, superiores $(\bar{m}=0,25)$ ao teor mínimo adequado proposto, que é de 0,22. A acumulação de $\mathrm{P}$, geneticamente con trolada, não é afetada pela absorção de outros elementos como $\mathrm{K}, \mathrm{Ca}, \mathrm{Mg}, \mathrm{Mn}, \mathrm{Fe}, \mathrm{Cu}, \mathrm{B}, \mathrm{Al}, \mathrm{sr}$ e $\mathrm{Zn}$, conforme relataram $\mathrm{BA} \underline{\mathrm{R}}$ BER et alii (1967). Por outro lado, BAKER et alii (1971), tra balhando com populàções selecionadas de milho para alto e bai xo teor de fósforo nas folhas, verificaram que a concentração deste elemento pode estar associada a uma maior : concentração de $\mathrm{N}$, e menor de $\mathrm{Fe}, \mathrm{Al}$ e possivelmente Mn nas folhas. Ainda com relação ao fósforo, estudiosos como BARBER et alii (1967); BAKER et alii (1970) e BAKER et alii (1971) verificaram que o caráter genético para maior acumula ção de fósforo, não é, necessariamente, traduzido em maior pro dução de grãos. Assim, as variedades que apresentam baixa acu mulação devem fazer uma certa economia desse nutriente, atra vés de uma maior taxa de conversão de nutrientes em grãos.

O $\mathrm{K}$ desempenha inúmeras funções fisiológicas den 
tro das células e, aliado à luz destaca-se como responsável direto pelo mecanismo de abertura e fechamento dos estômatos; em sua falta os estômatos não se abrem regularmente, há menor entrada de gás carbônico e, portanto, menor intensidade fotos sintética. Ainda pela anālise dos dados do Quadro 19, obser va-se que os teores de $K$ presentes nas folhas de todos os ma teriais de milho aos 70 dias após a semeadura sempre foram sua periores $(\bar{m}=3,31)$, àquele proposto, que é da ordem de 2,00. Com relação aos fertilizantes, o teor médio de $\mathrm{K}$ nas folhas apresenta-se com valor igual a 3,22 no caso do mineral e 3,39 para o orgânico, sendo em ambos os casos maior que o mínimo proposto.

Analisando os teores de Ca presentes nas folhas aos 70 dias após a semeadura, observa-se que entre os mate riais este teor apresenta-se com um valor médio ao redor de 0,42, que é o mesmo valor médio observado em relação aos fier tilizantes e, neste caso, ambos estão abaixo do teor mínimo adequado proposto que é de 0,45 .

Con relação ao teor de $\mathrm{Mg}$ presente nas folhas aos 70 dias após a semeadura, verifica-se que tanto para os materiais de milho $(0,21)$ como o teor médio deste elemen to para os fertilizantes $(0,17)$, acha-se abaixo do teor mini mo adequado proposto que é de 0,25 .

A absorção do Mg pelas plantas se faz de modo semelhante ao do $\mathrm{K}$. Há referências na literatura que abordam - aspecto do antagonismo entre $\mathrm{Mg}$ e $\mathrm{Ca}$ de um lado e $\mathrm{Mg}$ e $\mathrm{K}$ de 
outro, onde o aumento na concentração de um elemento no meio nutritivo implica na diminuição da absorção do outro.

\subsubsection{Micronut:rientes}

O Quadro 20 apresenta as análises dos teóres mé dios dos micronutrientes presentes nas folhas aos 70 dias apōs a semeadura. Obserṿa-se que não houve diferença signifí cativa com relação aos adubos, para o elemento $\mathrm{Fe}$, ocorrendo diferenças significativas para os outros micronutrientes.

Observando o componente Híbridos vs Compostos , com relação ao teor de $\mathrm{Cu}$ presente nas folhas, verifica - se que houve diferença significativa e que os Híbridos apresen tam um valor médio superior àquéle observado nos compostos.

Ainda com relação ao Quaủro 20 , atravēs dos vạ lores de F, observa-se que entre os Híbridos e entre os Com postos as diferenças foram não significativas quando se anali sa o teor de $\mathrm{Cu}$ presente nas folhas destes materiais aos 70 dias apōs a semeadura.

Com relação à interação A x M verifica-se que ela foi significativa para o Fe, Mn e para o $\mathrm{Zn}$. Objetivando melhor interpretar esta interação, realizou-se o desdobramen to dos graus de liberdade e, os valores dos micronutrientes Fe, Mn e Zn, em ppm, estão presentes no Quadro 21. De sua análi se depreende-se que o componente Piranão vs Demais apresentase não significativo para o $\mathrm{Fe}, \mathrm{Mn}$ e $\mathrm{Zn}$ dentro do fertilizan te mineral, o mesmo acorrendo para o Fe e $\mathrm{Zn}$ dentro do ferti 
Quadro 20 . Valores de $F$, coeficientes de variação, médias dos materiais e médias dos adubos, para os teores mé dios dos micronutrientes (ppm) presentes nas fo lhas aos 70 dias.

\begin{tabular}{|c|c|c|c|c|}
\hline \multirow{2}{*}{$\begin{array}{l}\text { Causas de } \\
\text { Variação }\end{array}$} & \multicolumn{4}{|c|}{ Elementos } \\
\hline & $\mathrm{Cu}$ & $\mathrm{Fe}$ & $\mathrm{Mn}$ & $\mathrm{zn}$ \\
\hline Adubos (A) & $53,45 * *$ & $0,64^{\mathrm{ns}}$ & $13,93 * \%$ & $4,21 *$ \\
\hline Piranão vs Demais & $0,61^{\mathrm{ns}}$ & - & - & - \\
\hline Híbridos vs Compostos & $10,95 * *$ & - & - & - \\
\hline H.D. vs Dina 10 & $0,30^{\mathrm{ns}}$ & - & - & - \\
\hline C.F. vs C.D. & $0,68^{\mathrm{ns}}$ & - & - & - \\
\hline Interação $A \times M$ & $0,80^{\text {ns }}$ & $3,22 *$ & $4,08 *$ & $4,48 * *$ \\
\hline C.V. $\frac{8}{8}$ & 4,56 & 15,93 & 11,77 & 8,38 \\
\hline
\end{tabular}

Médias dos Materiais

\begin{tabular}{llllc}
\hline Piranão & 20,13 & - & - & - \\
H.D. & 20,50 & - & - & - \\
C.F. & 19,25 & - & - & - \\
C.D. & 19,50 & - & - & - \\
Dina 10 & 20,25 & - & - & - \\
\hline
\end{tabular}

Médias dos Adubos

\begin{tabular}{lllll}
\hline Mineral & 20,95 & 222,45 & 38,10 & 35,95 \\
Orgânico & 18,85 & 231,60 & 31,15 & 34,00 \\
\hline
\end{tabular}

ns $=$ não significativo $(P>0,05)$

* = significativo $(\mathrm{P}<0,05)$

$* *=$ significativo $(P<0,01)$ 
Quadro 21. Valores de F para o desdobramento dos graus de liber dade da interação adubos $x$ materiais $(A \times M)$ e mé dias dos materiais dentro de cada fertilizante para os micronutrientes $\mathrm{Fe}, \mathrm{Mn}, \mathrm{Zn}(\mathrm{ppm})$, aos 70 dias.

\begin{tabular}{|c|c|c|c|c|c|c|}
\hline \multirow[t]{2}{*}{$\begin{array}{l}\text { Causas de } \\
\text { Variação }\end{array}$} & \multicolumn{3}{|c|}{$\begin{array}{c}\text { Dentro do Fertilizante } \\
\text { Mineral } \\
\end{array}$} & \multicolumn{3}{|c|}{$\begin{array}{c}\text { Dentro do Fertilizante } \\
\text { Orgâni co }\end{array}$} \\
\hline & $\mathrm{Fe}$ & $\mathrm{Mn}$ & $\mathrm{Zn}$ & $\mathrm{Fe}$ & $\mathrm{Mn}$ & $\mathrm{Zn}$ \\
\hline Piranão vs Demais & $1,46^{\mathrm{ns}}$ & $0,52^{\mathrm{ns}}$ & $1,59^{\mathrm{ns}}$ & $0,10^{\mathrm{ns}}$ & $7,39 *$ & $2,33^{n S}$ \\
\hline Híbridos vs corpostos & $0,03^{\mathrm{ns}}$ & $5,97 * *$ & $7,94 * *$ & $0,30^{\text {ns }}$ & $13,65 * *$ & $4,20 *$ \\
\hline H.D. vs Dina 10 & $13,29 * *$ & $16,37 * *$ & $0,36^{\mathrm{ns}}$ & $0,07^{\mathrm{ns}}$ & $0,11^{\mathrm{ns}}$ & $7,06 *$ \\
\hline C.F. VS C.D. & $1,38^{\mathrm{ns}}$ & $0,18^{\text {ns }}$ & $3,73^{\mathrm{ns}}$ & $6,16 *$ & $0,26^{\mathrm{ns}}$ & $4,72 *$ \\
\hline
\end{tabular}

Médias dos Materiais

\begin{tabular}{lllllll}
\hline Piranão & 242,00 & 36,75 & 34,25 & 236,75 & 38,25 & 36,00 \\
H.D. & 262,50 & 47,00 & 39,00 & 228,75 & 35,25 & 32,25 \\
C.F. & 204,25 & 35,25 & 32,50 & 267,00 & 27,25 & 34,25 \\
C.D. & 234,25 & 36,50 & 36,25 & 203,50 & 28,75 & 29,75 \\
Dina 10 & 169,25 & 35,00 & 37,75 & 222,00 & 36,25 & 37,75 \\
\hline
\end{tabular}

$$
\begin{aligned}
& \text { ns }=\text { não significativo }(P>0,05) \\
& *=\text { significativo }(P<0,05) \\
& * *=\text { significativo }(P<0,05)
\end{aligned}
$$


lizante orgânico e, significativo para o Mn no orgânico. Pela média dos materiais, com relação ao Mn, observa-se que o Pira ñăo apresenta o maior valor médio em comparação com os demais materiais, dentro do fertilizante orgânico.

Para O Híbridos vs Compostos, verifica-se que

não houve diferença significativa para $\mathrm{Fe}$, tanto dentro do fertilizante mineral quanto do orgânico; para o Mn e o $\mathrm{Zn}$ ocor rem significativas nos fertilizantes mineral e orgânico e, ve rifica-se que os Híbridos aparecem com maior valor médio para os micronutrientes $\mathrm{Mn}$ e $\mathrm{Zn}$, dentro do fertilizante mineral, o mesmo comportamento é observado também dentro do fertili zante orgânico.

Com relação aos Híbridos, observa-se que as di ferenças foram não significativas para o $\mathrm{Zn}$, dentro do ferti lizante mineral e para o Fe e Mn dentro do fertilizante orgâa nico; significativas para o Fe e Mn, dentro do fertilizante mineral e para $\circ \mathrm{Zn}$ dentro do fertilizante orgânico, consta tando-se que o Híbrido Duplo apresenta teores superiores de Fe e Mn em comparação com o Dina 10, dentro do fertilizante mineral. Dentro do fertilizante orgânico o Híbrido Duplo apresenta teores inferiores em relação ao Dina 10 para $\circ \mathrm{Zn}$. Observando o comportamento dos compostos, veri fica-se que as diferenças foram não significativas para o Fe, Mn e $\mathrm{Zn}$, dentro do fertilizante mineral e para o Mn den tro do fertilizante orgânico, enquanto que para o Fe e $\mathrm{Zn}$, den tro do fertilizante orgânico as diferenças foram significati 
vas, com o Composto Flint apresentando superioridade nos teo res de $\mathrm{Fe}$ e $\mathrm{Zn}$.

Alguns estudiosos como GERLOFF (1963), EPSTEIN \& JEFFERIES (1964), SPRAGUE (1969) e EPSTEIN (1972) apresen taram citações sobre a influência do ge rmoplasma na absorção, translocação e utilização de nutrientes nas plantas.

Procurando elucidar o mecanismo de absorção do Fe pelas plantas, CLARK \& BROWN (1974) cultivaram, separadą mente e juntos, em solução nutritiva, dois materiais de mi lho, genotipicamente diferentes. A presença da linhagem " efi ciente" não beneficiou algumas substâncias redutoras para a solução. Estes autores concluiram que, os fatores para " efi ciência" devem agir internamente, e não externamente.

Por outro lado, BROWN et alii (1972). constata ram que as linhagens de milho ineficientes para a absorção de ferro apresentaram maiores concentrações de $\because$ fosfato $\left(\mathrm{H}_{2} \mathrm{PO}_{4}^{-}\right)$, cobre $(\mathrm{Cu}++)$ e outros ions antagônicos ao $\mathrm{Fe}$.

HALIN et alii (1968) verificaram que o grau de deficiência do zinco em milho depende do genótipo, sendo que algumas variedades apresentam deficiência mais acentuada no início do ciclo e outras, no final.

Trabalhos desenvolvidos por VAsCONCEIros et alii (1983) demonstraram haver diferença entre cultivares quanto à taxa de conversão de nutrientes assinilados em grãos, alertando ainda que hã, um objetí vo a ser perseguido quanto à eficiência de cultivares em utili zar mais eficientemente os nutrientes aplicados. 


\subsection{Avaliação da Produção}

O Quadro 22 reporta as análises para os dados de produção em suas vārias expressões, na amostragem realizạ da aos 150 dias após a semeadura.

\subsubsection{Comprimento das Espigas}

Através dos valores de $F$ presentes no Quadro 22, verifica-se que para o parâmetro comprimento das espigas, no que se refere aos Adubos, as diferenças foram não significatí vas, indicando que os tipos de fertilizantes não influem nes s a característica.

Ainda através dos dados do Quadro 22 , observa-se que a interação A x M foi significativa. Objetivando melhor esclarecer este comportamento, realizou-se o desdobramento dos graus de liberdade desta interação apresentado no Quadro 23. Pela análise do Quadro, observa-se que o componente Pira não vs Demais, dentro do fertilizante mineral, não foi signi ficativo, o que ocorre dentro do orgânico, com o Piranão apre sentando comprimentos de espigas inferiores aos dos demais materiais. 


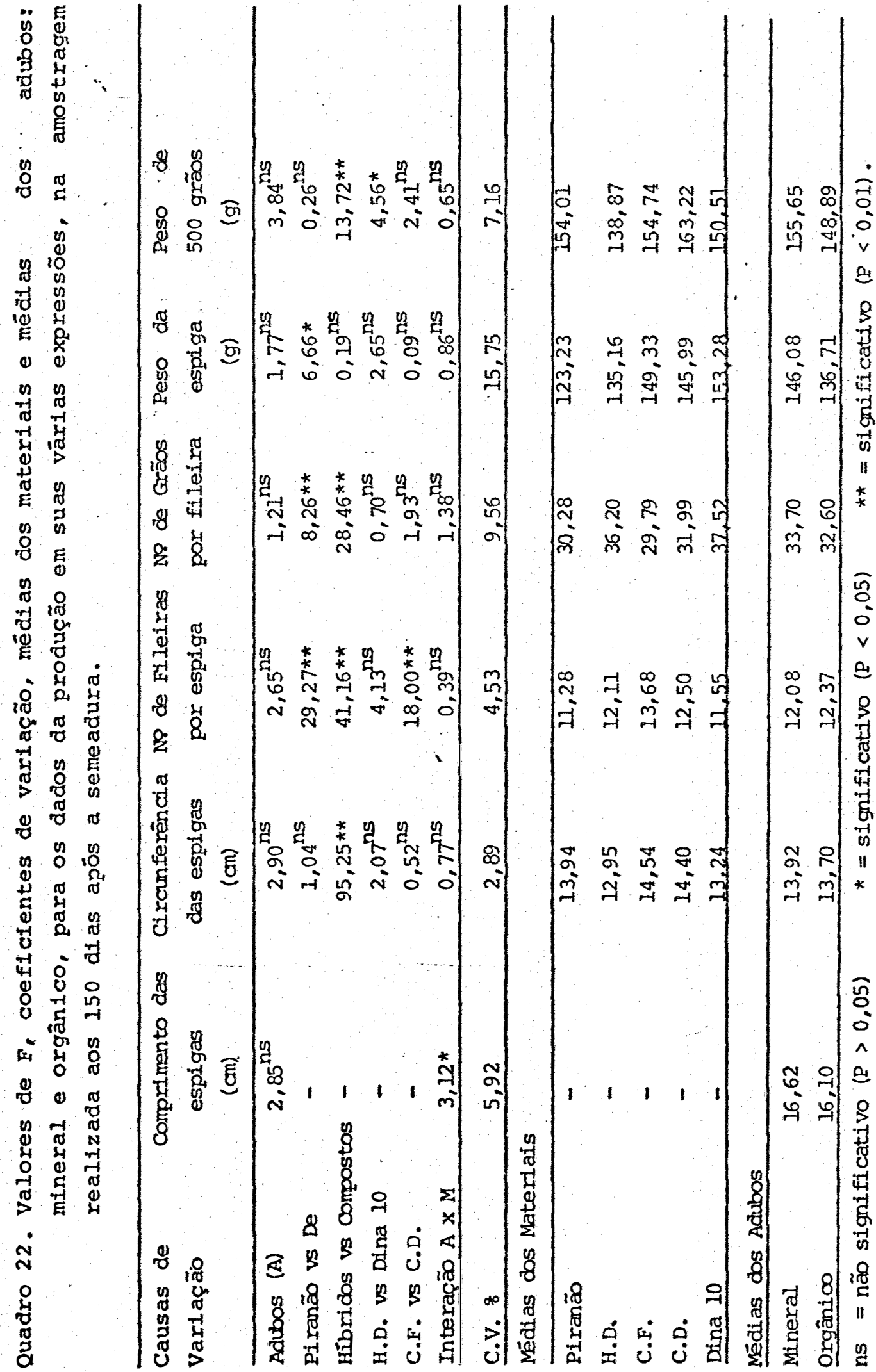


Quadro 23. Valores de F para o desdobramento dos graus de li berdade da interação adubo $x$ materiais ( $\mathrm{A}$ M) e médias dos materiais dentro de cada fertilizante para os dados de comprimento das espigas, aos 150 dias.

Causas de

Variação

Piranão vs Demais

Híbridos vs Compostos

H.D. vs Dina 10

C.F. vs C.D.
Dentro do Fertili Dentro do Fertili zante Mineral zante Orgânico

Médias dos Materiaịs

$\begin{array}{cc}1,88^{\mathrm{ns}} & 20,29 * * \\ 11,59 * * & 8,27 * \star \\ 0,03^{\mathrm{ns}} & 8,73^{* *} \\ 3,53^{\mathrm{ns}} & 0,61^{\mathrm{ns}}\end{array}$

$\begin{array}{lcc}\text { Piranão } & 16,02 & 14,15 \\ \text { H.D. } & 17,54 & 16,28 \\ \text { C.F. } & 16,59 & 15,62 \\ \text { C.D. } & 15,30 & 16,16 \\ \text { Dina 10 } & 17,65 & 18,30\end{array}$

ns $=$ não significativo $(P>0,05)$

** $=$ significativo $(P<0,01)$ 
Para o componente Híbridos vs Compostos, verifi ca-se que ocorrem diferenças significativas entre estes mate riais, tanto dentro do fertilizante mineral como do orgânico e, pelas médias, observa-se que os Híbridos aparecem com va lores médios superiores àqueles dos Compostos, independemen te do tipo de fertilizante.

Entre os Hibridos, observa-se que houve diferen ça significativa para o parâmetro comprimento das espigas,com - valor médio alcançado pelo Híbrido Duplo $(16,28 \mathrm{~cm})$ inferior ao do Dina $10(18,30 \mathrm{~cm})$ para o fertilizante orgânico, ao passo que, para o fertilizante mineral não se constata di ferença significativa entre esses materiais.

Analis ando o comportamento dos Compostos, veri fica-se que as diferenças entre estes materiais, com relação ao comprimento das espigas, não foram significativas.

Finalmente, com relação ao parâmetro comprimen to das espigas, pode-se auferir que o fertilizante mineral apresenta um valor médio superior $(16,62)$ ao do fertilizante orgânico, que é de $(16,10)$.

\subsubsection{Circunferência das Espigas}

Com relação aos dados de circunferência das es pigas apresentados no Quadro 22, verifica-se que as diferen ças foram não significativas com relação aos tipos de adubos utilizados, indicando que estes não influem na circunferência 
das espigas.

Observando o comportamento dos diversos mate riais de milho, verifica-se que para o componente Piranão vs Demais, entre os Híbridos e entre os Compostos as diferenças, quanto aos valores médios de circunferência das espigas, foram não significativas, enquanto que para o componente, Híbridos vs Compostos, estas diferenças foram significativas, consta tando-se que os compostos apresentam-se com valores médios su periores aos dos Híbridos.

Com relação à interação A x M, ainda pelo Quadro 22, observa-se que as diferenças com relação à circunferên cia das espigas, foram não significatịas.

\subsubsection{Número de Fileiras de Grãos por Espiga}

Analisando o nümero de fileiras de graõs por es piga, cujos dados estão apresentados no Quadro 22, verifica se que as diferenças observadas com relação à este parâmeţro, foram não significativas quando se analisam as seguintes cau sas de variação: Adubos, entre Híbridos e a interação A x M.

Analisando o componente Piranão vs Demais, ob serva-se que o Piranão apresenta o menor número de fileiras de grãos por espiga $(11,28)$ de todos os materiais utilizados. Para o componente Híbrido vs Compostos, obser va-se que os Compostos apresentam um vajor médio maior $(13,09)$ do que o dos Hỉbridos $(11,83)$, com relação ao número de fi 
leiras de grãos.

Observando o comportamento dos Compostos, com relação ao número de fileiras de grãos poor espiga, verifica se que o Composto Flint apresenta um valor médio maior do que o Composto Dentado.

Finalmente, com relação ao tipo de fertilizan te, ainda com base nos dados apresentados: no Quadro 22, verí fica-se que a média do fertilizante orgânico $(12,37)$ é maior do que a do fertilizante mineral $(12,08)$ com relação ao núme ro de fileiras de grãos por espiga.

\subsubsection{Número de Grãos por Fileira}

Os dados relativos ao número de grãos por fi leira encontram-se apresentados no Quadro 22, através do qual verifica-se que as diferenças observadas, com relação aos tipos de adubos utilizados, não foram significativas.

Com relação aos materiais de milho utilizados, observa-se que as diferenças foram não significativas entre os Híbridos e entre os Compostos e, significativas para Pira não vs Demais e Híbridos vs Compostos.

Através das médias dos materiais, verificase que o Piranão aparece com o menor valor médio $(30,38)$, quan to ao parâmetro número de grãos por fileira, observando-se , também que o valor médio dos composto $(30,89)$ é menor que o dos Híbridos $(36,86)$. 
Observando o comportamento dos compostos veri fica-se, através das médias destes materiais, que o compos to Flint apresenta média de número de fileiras de grãos por es piga', maior do que aquela observada para o Composto Dentado. Analisando a interação $\bar{A} \times \mathbb{M}$, através dos vą lores de F, observa-se que as diferenças foram não sig nificativas com relação ao parâmetro de fileiras de graõs por espiga.

Finalmente, verifica-se através dos valores das médias dos fertilizantes utilizados, que o mineral apresenta um valor maior $(33,70)$ que o fertilizante orgânico $(32,60)$.

\subsubsection{Peso da Espiga Principal}

Com relação ao peso da espiga principal, pelos dados do Quadro 22, observa-se que as diferenças foram não significativas para Adubos, indicando que os tipos de ferti lizante não afetam o peso da espiga.

Analisando o comportamento dos materiais, veri fica-se que as diferenças foram significativas apenas para Piranão vs Demais, com o Piranão apresentando espigas com me nor peso $(123,23 \mathrm{~g})$ em relação aos demais $(145,94 \mathrm{~g})$.

\subsubsection{Peso de Quinhentos Grãos}

Através do Quadro 22, com relação ao parâmetro 
peso de quinhentos graõs, verifica-se que as diferenças foram não significativas quanto ao tipo de adubos utilizados, cons tatando-se diferenças significativas apenas para Híbridos vs Compostos e entre os Híbridos.

Analisando as médias dos materiais, obsèrva-se, no cáso dos Híbridos vs Compostos, que o maior valor médio $(158,98 \mathrm{~g})$ foi obtido pelos Compostos, contra o valor médio $(144,69 \mathrm{~g})$ para os Híbridos, em relação ao peso de quinhentos grãos.

- Observando o comportamento dos Híbridos, verifi ca-se que o peso de quinhentos grãos foj superior $(150,51 \mathrm{~g})$ para o Dina 10, em comparação ao do Híbrido Duplo que foi de $(138,87 \mathrm{~g})$.

\subsection{Análise Qualitativa da Produçäo}

\subsubsection{Proteína Total dos Grãos}

Com relação ao teor de proteína dos grãos, cujos dados estão apresentandos no Quadro 24 , observa-se que as di ferenças, com relação aos tipos de fertilizantes, não são sig nificativas.

Com relação ao comportamento dos diversos cultí vares de milho utilizados, com base no teor de proteína dos graõs, observa-se que, as diferenças foram significativas ape nas para.os seguintes componentes: Híbridos vs Compostos e en 
tre os Híbridos.

Pela anālise das médias dos cultivares, observase que os compostos apresentam um valor médio superior $(8,87 \%)$ ao dos Híbridos, que foi de 8,49(\%)de proteína nos graõs e , que o Dina 10 apresenta um teor de proteína nos grãos supe rior $(8,83 \%)$ ao do Híbrido Duplo $(8,16 \%)$.

Alguns autores como ALEXANDER et alii (1969) , LOFFER \& BUSCH (1982) e CARTER et alii (1982), analisando o comportamento de vārias plantas cultivadas, constataram que rendimento de grãos e percentagem de proteína nele contida , não apresentam 'correlação linear.

Com relação à interação A x M verifica - se que as diferenças, quanto ao teor de proteína dos graõs, foram não significativas, e observando-se as : anâlises dos fertilizantes utilizados, verifica-se que o mineral apą rece com um valor médio superior $(8,83)$ ao do orgânico, $\mathrm{c} 0 \mathrm{~m} 8,51$.

O Quadro 25 mostra, em resumo; o comportamento dos diversos cultivares de milho estudados, em relação às ca= racteristicas analisadas, assim como, os valores de $F$, para a causa de variação adubos e a média final observada em relação ao tipo de fertilizante utilizado. 
Quadro 24. Valores de F, coeficientes de variação, médias dos materiais e médias dos adubos para os dados de - teor de proteína $(\%)$ dos grãos.

\begin{tabular}{ll}
\hline Causas de & Valor de \\
Variação & $F$ \\
\hline Adubos (A) & $3,70^{\mathrm{ns}}$ \\
Piranão vs Demais & $0,06^{\mathrm{ns}}$ \\
Híbridos vs Compostos & $4,22^{*}$ \\
H.D. vs Dina 10 & $6,38^{*}$ \\
C.F. vs C.D. & $3,81^{\mathrm{ns}}$ \\
Interação A X M & $2,17^{\mathrm{ns}}$ \\
\hline C.V. \& & 6,08 \\
\hline Piranäo & 8,63 \\
H.D. & 8,16 \\
C.F. & 9,13 \\
C.D. & 8,61 \\
Dina 10 & 8,83 \\
\hline
\end{tabular}

Médi as dos Adubos

\begin{tabular}{ll}
\hline Mineral & 8,83 \\
Orgânico & 8,51 \\
\hline
\end{tabular}

ns = não significativo $(\mathrm{p}>0,05)$

* = significativo $(P<0,05)$

$\star \star=$ significativo $(P<0,01)$ 
Quadro 25. Comportamento dos diversos cultivares de milho estu彑 dados em função dos parâmetros analisados, valores de $F$ para a causa de variação Adubos e médias dos tipos de fertilizante utilizados.

\begin{tabular}{|c|c|c|c|c|c|c|c|}
\hline $\begin{array}{l}6 \\
b \\
0 \\
c \\
a\end{array}$ & PARAMETROS & & PIRAKÁO & $\begin{array}{c}\text { MTBRIDO } \\
\text { DLPLO }\end{array}$ & $\begin{array}{l}\text { COMPOSTO } \\
\text { RINT }\end{array}$ & $\begin{array}{l}\text { CORPOSTO } \\
\text { DENTADO }\end{array}$ & $\begin{array}{l}\text { MIBRIDO } \\
\text { DIKA } 10\end{array}$ \\
\hline \multirow{10}{*}{ 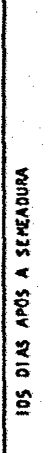 } & \multicolumn{2}{|c|}{ altura da planta $(\mathrm{cm})$} & & & $x$ & & \\
\hline & \multicolumn{2}{|c|}{ MOMERO DE FOLHAS } & & & $x$ & & \\
\hline & \multicolumn{2}{|c|}{ AREA FOLIAR $\left(\mathrm{dm}^{2}\right)$} & & & $x$ & & \\
\hline & \multicolumn{2}{|c|}{ COMPRIMENTO DO COLHO $(\mathrm{cm})$} & & & $x$ & & \\
\hline & \multirow{5}{*}{ א } & & & & & $x$ & \\
\hline & & & & & & $x$ & \\
\hline & & & & & & $x$ & \\
\hline & & $U L I N A$ & & & & $x$ & \\
\hline & & NINA & & & & & $x$ \\
\hline & \multicolumn{2}{|c|}{ Materia SECa total (g) } & & & & $x$ & \\
\hline & \multirow{9}{*}{ 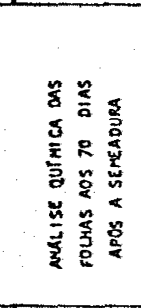 } & $x$ & $x$ & & & & \\
\hline & & $P$ & & $x^{m}$ & & & \\
\hline & & $x$ & & & & & \\
\hline & & $c_{a}$ & $x$ & $x$ & & & $x$ \\
\hline & & $\mathrm{Ha}$ & & $x^{\circ}$ & & & \\
\hline & & $\mathrm{Cu}$ & & $x^{n}$ & & & \\
\hline & & se. & & $x^{n}$ & & & \\
\hline & & m & & $x^{n}$ & & & \\
\hline & & $2 n$ & & $x^{n}$ & & & \\
\hline & \multicolumn{2}{|c|}{ PRODUÇ $\mathrm{AO}_{0}$} & & & & & \\
\hline & \multicolumn{2}{|c|}{ COPRIMERTO DAS ESPICAS (cm) } & & & & & $\mathbf{x}$ \\
\hline & \multicolumn{2}{|c|}{ IIRCLNF. OAS ESPICAS (cm) } & & & $x$ & & \\
\hline \multirow{5}{*}{ 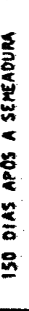 } & \multicolumn{2}{|c|}{$\begin{array}{l}\text { No DE FILEIRAS DE ERTOS POR } \\
\text { ESPICA }\end{array}$} & & & $x$ & & \\
\hline & \multicolumn{2}{|c|}{ NE: OC CRAO POR FILEIRS } & & & & & $x$ \\
\hline & \multicolumn{2}{|c|}{ PESO OA ESPIGA PRINCIPAL(g) } & & & & & $x$ \\
\hline & \multicolumn{2}{|c|}{ PESO DE QUINHERTOS GPAOS $(g)$} & & & & $x$ & \\
\hline & \multicolumn{2}{|c|}{ Protetra total cos Graos(z) } & & & $x$ & & \\
\hline
\end{tabular}

\begin{tabular}{|c|c|c|}
\hline \multirow{2}{*}{$\begin{array}{c}\text { CAUSA DE VARIAÇAO } \\
\text { aDUBOS }\end{array}$} & \multicolumn{2}{|c|}{ reOIAS } \\
\hline & RINERAL & ORCRNICO \\
\hline $1,02^{\mathrm{ns}}$ & 185,40 & 189,38 \\
\hline $0.33^{n s}$ & 10,64 & 10.49 \\
\hline $0.56^{\mathrm{ns}}$ & 285.54 & 263.20 \\
\hline $0.15^{\mathrm{ns}}$ & 188.85 & 185,89 \\
\hline$-n .0 e^{n s}$ & -52.31 & 52.30 \\
\hline $0,19^{\mathrm{ns}}$ & 15,64 & 15,10 \\
\hline $0.30^{\mathrm{ns}}$ & 24.31 & 23.46 \\
\hline $0,00^{n s}$ & 4.33 & 4.32 \\
\hline $0.26^{\mathrm{ns}}$ & 120.80 & 116,26 \\
\hline $0.21^{\mathrm{ns}}$ & 217.39 & 211.46 \\
\hline $26.31 . *$ & 3.38 & 1.23 \\
\hline 18.52. & -2.35 & 0.21 \\
\hline $2.33^{n s}$ & $-3.2 x$ & -3.39 \\
\hline $0.06^{\mathrm{ns}}$ & 0,42 & 0.42 \\
\hline 12,030 & 0.16 & 0,18 \\
\hline $53.45^{\circ}$ & 20,95 & 18,85 \\
\hline $0.64^{\mathrm{ns}}$ & 222.45 & 231.60 \\
\hline $13.23^{\circ} \cdot$ & 18,10 & 33.15 \\
\hline $4.21^{\circ}$ & -35.95 & 34,00 \\
\hline- & - & - \\
\hline $2.85^{\mathrm{ns}}$ & 16.62 & 16,10 \\
\hline $2.90^{\mathrm{ns}}$ & 13.92 & 13.70 \\
\hline $2.65^{n 3}$ & 12,08 & 12.37 \\
\hline $1.21^{\mathrm{ns}}$ & 33,70 & 32,60 \\
\hline $1,77^{\mathrm{ns}}$ & 146,08 & 136,71 \\
\hline $3.84^{\mathrm{ns}}$ & 155,65 & 148,89 \\
\hline $3, i^{n e}$ & 8,83 & 8.51 \\
\hline
\end{tabular}

$\mathrm{X}=$ valores mais elevados, nas diversas épocas de amostragens.

$\mathrm{X}^{0}=$ no fertilizante orgânico.

$x^{m}=$ no fertilizante mineral. 


\section{CONCLUSÕES}

Após os estudos efetuados com a cultura do mị lho (Zea mays L.), atràvés dos seguintes cựtivares: Piranão, Híbrido Duplo 7974, Composto Flint, Composto Dentado e Híbrí do Dina 10 e duas fontes de nutrientes, no caso fertilizante mineral e fertilizante orgânico, com aplicação de quantidades equivalentes a $60 \mathrm{~kg} / \mathrm{ha}$ de nitrogênio, observadas as condi ções em que foi conduzida a presente pesquisa, e após a anā lise dos resultados obtidos, pode-se concluir que:

a) De maneira geral, as diferenças observadas no desenvolvimento dos diversos materiais de milho estudados não foram devidas ao tipo de fertilizante utilizado.

b) O mesmo comportamento observa-se com relação aos parâmetros de produção analisados, ou seja, as diferen ças observadas não foram significativas com relação às fontes 
de nutrientes utilizadas.

c) A melhor resposta, em termos de peso da espi ga principal, foi obtida pelo Híbrido Dina 10.

d) Quanto ao teor de proteína total dos grãos, observa-se que o maior valor médio em $\frac{q}{\partial}$, foi obtido pelo Com posto Flint.

Deve-se ressaltar que as respostas observadas no presente trabalho foram obtidas com a aplicação dos fertili zantes: mineral de forma tradicional (semeadura + cobertura) e o fertilizante orgânico, na quantidade equivalente, de uma só vez, aproximadamente uma semana antes da semeadura. Necessá rio se toma realizar pesquisas com tempo de duração longo, objetivando analisar não só o comportamento de diferentes cul turas, mas também o efeito da aplícação destes fertilizantes no solo ao longo dos anos. 
6. LITERATURA CITADA

ALEXANDER, D.E.; R.J...LAMBERTI J.W. DUDLEY , 1969. Breeding problems and potentials of modified protein maize. New ap proaches to breding for improved plant protein. Vienia, Internacional atomic Energy Agency. p. 55-65.

ALLEN, J.R.; J.R. MCKEE; J.H. MCGAHEN, 1973. Leaf number and maturity in hybrid corn. Agron. J., 65:233-235.

ALOISI, R.R.; J.L.I. DEMATTE, 1974. Levantamento dos solos da Faculdade de Medicina Veterinária e Agronomia de Jaboticabal. Científica, 2(2):123-136. 
AMBERGER, A.; R. GUTSER; A. WUNSCH, 1980. The effect of se wage sludge compost on yield and mineral uptake of crop plants in comparison with mineral $\mathrm{N}$ fertilization. Baye. risches Lan dwirstchaftliches, 57(2) :148-155.

ANDERSON, J.C. e P.N. CHOW, 1963. Phenotypes and grain yield associated with brachytic - 2 gene in single-cross hybrids of dent corn. Crop Sci., 3:111-113.

ANDERSON, C.K.; L.R. STONE; L.S. MURPHY, 1982. Cron yield as influenced by in-season application of nitrogen with limited irrigation. Agron. J., 74:396-401.

A.O.A.C. 1970. Official methods of analysis of the associa tion official analytical chemistry. lla ed., Washington, A.O.A.C., 1015 p.

ASHBURN, E.L., 1971. The yield and uptake of nutrients by se lected corn genotypes as influenced by nitrogen fertiliza tion. Dissert. Abst. Intern. B., 32:33.

ASMUS, F.; H. CORLITZ; H. KORIATH, 1979. The determination of the organic matter requeriments of soils. Archiv fur Acker-und Pl fanzanbau und Bodenkid, 23(1) :13-20. 
BARBER, W.D.; W.I. THOMAS e P.E. BAKER. 1967. Inheritance of relative phosphorus accumulation in com (Zea mays L.) Crop Sci., 6: $104-107$.

BARBER, W.D. e W.I. THOMAS, 1972. Evaluation of genetics of relative phosphorus accumulation by corn (Zea mays L.) using chromossomal translocations. Crop Sci., 12: 755-758.

BAKER, D.E.; B.R. BRADFORD e W.I. THOMAS, 1970. Phosphorus uptake from soils by com hibrids selected for high and low phosphorus accumulation. Agron. J., 62:103-106.

BAKER, D.E.; F.J. WOODING e M.W. JOHNSON, 1971. Chemical ele ment accumulation by population of corn (Zea mays L.), se lected for high and low accumulation of P. Agron. J., 63: $404-406$

BATAGLIA, O.C. e H.A.A. MASCARENHAs, 1977. Absorção de nu -trientes pela soja em latossolo roxo sob vegetação do cer rado. Campinas, Instituto Agronômico, p. 36. ( Boletim Técnico, 41).

BATAGLIA, O.C.; TEIXEIRA, J.P.F.; FURLANI, P.R.; FURLANI, A. M.C. e GALLO, J.R., 1978. Análise Química de Plantas.Cam pinas Instituto Agronômico. 31 p. (Circular, 87). 
BONISCHOVA, Z, 1977. Effect of loquid manure on the plant. Rost linná Vyroba, 23(9):985-922.

BOSCHI, V. e D. SINISCHALCHI, 1979. The utilization of orga nic was the produced by intensive animal husband in Italy. Irrigation, 2:57-59.

BROWN, J.C.; J.E. AMBLER; R.L. CHANEY e C.F. FOY, 1972. Dif ferential response of plant genotypes to micronutrients . In: Nortvedt, J.J. et al, eds. Madison, Micronutrientes in agriculture. Soil Science Society of America, p. 389-4l3.

BUGUSLAWSKI, E. von, 1980. Utilization of sewage sludge of differents grades in arable fiarming. Zeitschrift_fur Acker-und Pflanzenbau, 194 (5):406-423.

BULLOW, J.F.W., 1971. Efeitos do gen braquítico - 2 em popu lações anālogas em híbrido de milho (zea mays L.). Pesqui. sa Agropecuāria Brasileira, 6: 155-161.

CARLETON, A.E. E FOOTE, W.H., 1975. A comparision of me thods for estimating total leaf area of barley plants Crop Sci., 5:603. 
CARTER Jr, T.J.; J.W. BURTON; C.A. BRIM, 1982. Recurrent se lection for percent protein in soybean seed. Indirect ef fects on plant $\mathrm{N}$ accumulation and distribution. Crop Sci., 22: $513-519$.

CHASE, S.S. P D.K. NANDA, 1966. What corn hybrids is the right maturity for your farm? Count the leaves. Crop and Soils, 18:8-9.

CHASE, S.S. e NANDA, D.K. 1967. Number of leaves and matu rity classification in zea mays L. Crop Sci., 7:413-432.

CLARK, R.B.; J.C. BROWN, 1974. Internal root control of iron uptake and utilization in maize genotypes. Plant and Soil, $40: 667-677$.

CROSS, H.Z. e M.S. ZUBER, 1973. Interrelationships anong plant height, number of leaves, and flowering dates in mai ze. Agron. J. 65:71-74

CROSBIE, T.M. e J.J. MOCK, 1981. Change in physiological traits associated with grain yield improvement in three maize bree-ding programs. Crop. Sci., 21:255-259. 
DARWINKELL, A. 1975. Aspects of assimilation and accumula tion of nitrate in some cultivated plants. Agric. Res. Rep., 843-864.

DELPHIN, J.E. e A.P. CONESA, 1979. Soil organic matter chan ges in a rotation, irrigation and plant residues trial in the Hardt plain. II. Humus balance. Annals Agronomigues. • França, $\underline{30}(2): 179-189$.

DIAZ, C.A. e G.A. RIVERA, 1978. Caracterization de genotí pos de maiz. Acumulation de matéria seca y determination del indice de cosecha in maices adaptados: a Ias zonas frias moderadas de Antioquia. Revista ICA Bogotá. Colom bia, $13(1): 21-32$.

DOUGLAS Jr., C.L.; R.R. ALLAMARA; P.E. RASMUSSEN, R.R. RAMIG e N.C. ROAGER Jr, 1980. Wheat straw composition and pla cement effects on decompisition in dryland agriculture of the Pacific Northwest. Soil Science Society of América Journal, 44 (4): 833-837.

DUNCAN, W.G. e J.D. HESKETH, 1968. Net photosynthetic ra tes, relative leaf growth rates, and leaf numbers of 22 ra ces of maize grown at light temperatures. Crop. Sci., $\underline{8}$ : $670-674$. 
EFREMOV, V.F., 1980. Effectiveness of organic fertilizers with winther application. Agroknimiya, 2:72-77.

EPSTEIN, E. 1972. Mineral nutrition of plants: principles and perspectives. New York, John Wiley and Sons, $412 \mathrm{p}$.

EPSTEIN, E. e R.L. JEFFERIES, 1964. The genetic basic of seletive ion transport in plants. Ann. Rev. Plant Phy siol., 15: 169-184.

F.A.O., 1977. China recycling of organic wastes in agricul ture. Roma, Feoples's Republic of China. 170 p. (Soil Bulletin, 40).

F.A.O. 1980. China azolla propagation and smal-scale biogas. technology. Roma, Study pour the Peoples's Republic of Chi na. $81 \mathrm{p}$.

FILIPPOV, G.L. e N.V. VISHINEVSKII, 1982. Basis of an eco logical and physiological model for a drought resistant maize hybrid. Byul. VNII KUkuruzy, 4:3-6, 1981 apud Plant Breeding Abstracts, $\underline{52}(4): 2903$. 
FOY, C.D. e S.A. BARBER, 1958. Magnesium absorpition and utilization by two inbred line of corn. Soil Sci.Soc.Amer. Proc. 22: 57-62.

FUJIYAMA, G.; T. TANIYAMA, S. TACHIBANA; O. MORITA, H.O. NA KANO; N. MIYASAKI e C. AKATSUKA, 1979. Effect of applí cation of large amounts of fresh farmyard manure on growth and yield on rice. Residual effect of pig manure on grain yield. Report of the Totali Brach of Crop Science of Ja pan, $84: 23-26$.

GAUR, A.C. e R.S. MATHAR, 1979. Effect of straw neem cake and farmyard manure on yield and nitrogen uptake by maize crop. Indian Joumal of Agronomy, 24 (4): 449-450.

GERLOFF, G.C., 1963. Comparative mineral nutrition of plants. Ann. Rev. Plant Physiol., 14:107-124.

GOMES GUTIERREZ, J.M.; B.G. CRIADO e E.L. CALABUIG, 1979. Process of incorporation of cattle dung into the soil. Sa lamanca, Centro de Edafologia y Biologia Applicada. p.145158. 
GREGORY, F.G. e F. GROWTHER, 1928. A physiological study of varietal difference in plants. Part I: A study of the comparative yields of barley varieties with different ma nurings. Ann. Bot., 42:757-770.

GUNASENA, H.P.M. e S. AHMED, 1977. Potential of organic ma nures and plant residues in crop production. Journal of the National Agricultural Society of Ceylon, 14:69-84.

HAAG, H.P.; A. BLUMENSCHEIN e R. VENCOVSKY, 1971. Influência genética na absorção de elementos nutritivos pela planta de milho. Relatório Científico do Instituto de Genética. ESALQ, $\underline{5}: 63-68$.

HALIN, A.H.; C.E. WASSON e R. ELLIS Jr, 1968. Zinc deficien cy simptoms and zinc and phosphorus interations in several strains of corn (zea mays L.). Agron. J. 60:267-271.

HANWAY, J.J., 1962. Corn growth and composition in relation to soil fertility: I. Growth of different plant parts and relation between leaf weight and grain yield. Agron. J. , 54: $145-148$.

HESKETH, J.D.; S.S. CHASE e D.K. NANDA, 1969. Environmental and genetics modification of leaf number in maize, sorghum and hungarian millet. Crop Sci., 9:460-463. 
HOYT, P. e R. BRADFIELD, 1962. Effect of varyng leaf area by partial defoliation and plant density on dry matter pro duction in corn. Agron. J., 54:423-525.

HUNDT, I. e H. GORLITZ, 1980. Investigation into the influen ce of high rates of slurry on the macronutrient content of some agricultural crops during the growing season. Ar

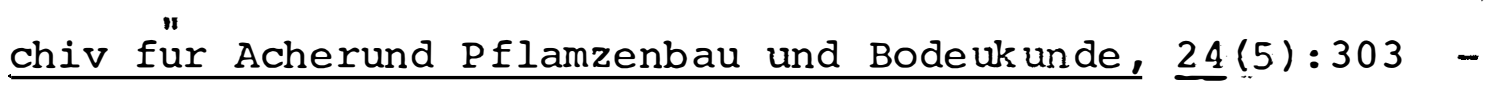
310 .

JEWELL, W.J. e M.S. SWITZENBAUM, 1978a. Agricultural wats . Journal Water Pollution Control Federation, 50(6):1152 1161 .

JEWELL, W.J. e M.S. SWITZENBAUM, 1978b. Agricultural wates. Journal water Pollution Control Federation, 50 (6): 1245 1257 .

KIEHL, E.J., 1979. Preparo do composto fazenda. Piracicaba , ESALQ. $10 \mathrm{p}$. 
KLIMASHEVSKII, E.L. 1966. The mecanism of response of various varieties of corn to root nutrition. Dokl. Akad. Nauk. SSSR, 168:1212-1213.

KOLLER, O.L, 1972. Maturação fisiológica e variação de ma téría seca e umidade durante o período de formação de grãos, em seis cultivares de milho. Porto Alegre, UFRGS , 137 p. (Tese de Mestrado).

KREJCIR, J. e K. RIMOVSKY, 1980. Effect of increasin slurry application rates in the physical properties of the soil. Rostlinnā Vyroba, 26(8):887-894.

LOFFER, C.M. e R.H. BUSCH, 1982. Selection for grain pro tein, grain yield, and nitrogen partitioning efficiency in hard red spring wheat. Crop Sci., 22:591-585.

MASCARENHAS, H.A.A.; N.R. BRAGA; M.A.C. MIRANDA; C.T. FEITO SA e O.C. BATAGLIA, 1980. Efeito de adubos verdes e orgâa nicos na produção de soja. Campinas, Instituto Agronômi col2 p. (Boletim Técnico, 63).

MAZUR, T.; J. KOC e Z. CIÉCKO, 1979. Comparison of the fer tilizer value of sfurry with that of farmyard manure and mineral fertilizer in pot experiments. Roczniki Clebozna waze, $30(2): 57-72$. 
MC NEAL, F.H.; BERG, M.A.; BROWN, P.L. e MC GUIRE, C.F. 1971. Productivity and quality response of five spring wheat genotypes, Triticum aestivum L. to nitrogen fertilizer. Agron. J. 63:908-910.

MEYER, B.S.; ANDERSON, D.B. e P.H. BOHNING, 1960. Introduc tion to plant physiology. New Jersey. Priceton.

MILTHORPE, F.L. e J.P. IVINS, 1970. The growth of cereal and grasses. In: DOGGETT, H. Sorghum. England, Longmans,403p.

MIRANDA FILHO, J.B., 1978. Herdabilidade da altura da plan ta e da espiga na população ESALQ - PBI - Relatório Cien tífico. Instituto de Genētica. Piracicaba, S.P. Brasil 12: $116-121$.

NEPTUNE, A.M.L., 1966. Estudos sobre adubação e diagnose fo liar do milho (Zea mays L.). Piracicaba, ESALQ, 167 p. (Te se cátedra).

ONISKO, W. e S. JANIC, 1978. The utilization in agriculture of waste otained during the production of fibreboardy by means of closed water circulation (pot experiments). Rol nictwo. Poland 17:85-99. 
O'RIORDAN, E., 1980. Use of servage sludge on agricultural

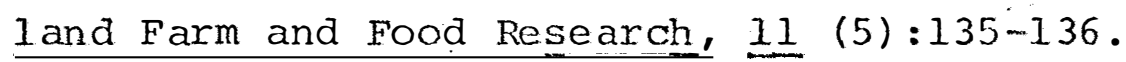

PATERNIANI, E. 1968. Formação de Compostos de milho. Pirací caba. Instituto de Genética, p.242. (Relatório Científico, 3).

PATERNIANI, E., 1980. Avaliação de cultivares de milhos bra quíticos. Piracicaba, Instituto de Genética, p. 61-68. (Re latório Científico, 14).

PATERNIANI, E., 1982. O tamanho do pendão e suas relações com a altura relatica da espiga, e com a produtividade do ensaio nacional de milho (Zea mays L.). In: XIV Resumos do Congresso Nacional de Milho e Sorgo, Florianopólis - SC. , p. 36 .

PEASLEE, D.F.; J.L. RAGLAND e W.G. DUNCAN, 1971. Grain fil 1 ling period of corn as influenced by phosphorus, potassium and the time of planting. Agron. J., 63:561-563.

PETRIKOVA, V., 1977. Efficacy of fertilization with fresh pig slurry on light and heavy soils. Postlinná Vyroba, 23 (4) : $353-359$. 
PHILLIPS, J.W.; D.E. BAKER e C.O. CLAGETT, 1971. Identifica tion of compounds which account for variation in $P$ concen tration in corn hybrids. Agron. J., 63: 541-543.

POYE, F.R.D., 1973. Otra jornada en la Recolution verde : Maices enanos en México. Agricultura de las Americas, 22: $20-38$.

RABIDEAU, G.S.; W.G. WHALEY e C. HEIMSCH., 1950. The absorp tion and distribution of radioactive phosphorus in two maize inbreds and their hybrid. Am. J. Bot., 37-93-99.

RAIJ, B. van e J.A. QUAGGIO., 1983. Métodos de análise de solo para fins de fertilidade. Campinas, Instituto Agronô mico, 31 p. (Boletim Técnico, 81).

ROOD, S.B. E D.J. MAJOR, 1981. Diallel analysis of leaf number leaf development rate, and plant height of early ma turing maize. Crop. Sci., 21:867-873.

ROOD, S.B. e D.J. MAJOR, 1981. Inheritance of tillering and flowering-time in early maturing maize. Euphytica, 2:327334 .

RUSSEL, E.W. 1976. Soil conditions and plant Growth. 10a. ed. Londres e Nova Iorque. Editora Longman. 
SARKADI, J.; H. BALLA; M. KRAMER e I. KADAR, 1979. Direct and residual effects of organic and mineral fertilizer ap plied in long-term experiments. Tangunsbericht,: Akademie der Landwir tchaftwissens chaften der Deustchen Demokra tischen Republik, 162:91-98. .

SCHMIDT, W.H. e W.L. COLVILLE, 1967. Yield and yield compo nents of zea mays $\mathrm{L}$. as influenced by artificially induced shade. Crop Sci., 7:137-140.

SCOTT, G.E. e C.M. CAMPBELL, 1969. Internode lenght in nor mal and brachytic - 2 maize inbreed and single crosses . Crop Sci. 9 9: 293-295.

SILVA, O., 1979. Adubação foliar e outras práticas. A Granja, 378: $33-40$.

SING, H. e B. RAI, 1979. Differences in morphological cha racters and yield of important maize genotypes and their recovered brachytic versions. Indian Journal of Agricultu ral science, 49: 758-763.

SKARDA, M.; J. JOKESOVA e I. PARIZEK, 1977. Efficacy of an nual fertilization with slurry in a crop rotation. Rostlin

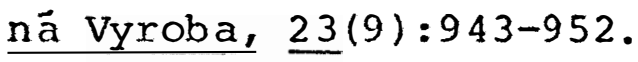


SNIDER, J.H., 1953. Strong roots make high corn yields. Bet ter Crops Plant Food., 37:17-19.

SOUZA'Jr., C.L. e ZINSLY, 1981. Avaliação de variedades de milho (zea mays L.) braquítico $-2 \mathrm{em}$ cruzamentos dialéti cos. Piracicaba, Instituto de Genética. p. 271-84. ( Relą tório Científico, 15).

SPRAGUE, G.F., 1969. Germ Plasm manipulation in the future. In: Eastin, J.D. et al., ed. Physiological aspects___ of crop yield. Madison, American Society of Agronomy. Crop Science of America, p. 375-395.

SOTOMAYOR, R.Y., 1979. Rèfuse compost as a source of organic fertilizer compared with chemical fertilizer. Part I. Agri cultura Técnica, Chile, 39 (4): 152-157.

TANAKA, A. e J. YAMAGUCHI, 1972. Dry matter yield components and grain yield of maize. Journal of the Faculty of Agriculture, Hokkaido, $\underline{5}(1): 72-132$.

TEMPLE - SMITH, M.G., 1979. Broiler litter and its use as a pasture. Journal of Agriculture. Tasmania, 50(2):46-49.

TIBAU, A.O., 1984. Matéria Orgânica e Fertilidade do Solo. 3a. ed. São Paulo. E.ditora Nobel, 220 p. 
TOLLENAAR, M.; 1977. Sink-source relationships during repro ductive development in maize. A review Maydica, 12:48-75.

TRANI, P.E.; R. HIROCE e O.C. BATAGLIA, 1983. Análise foliar. amostragem e interpretação. Campinas, Fundação Cargill , p. 18 .

TSAI, C.Y.; D.M. HUBER; D.V. GLOVER e H.L. WARREN, 1984. Rela tionships of $\mathrm{N}$ deposition to grain yield and $\mathrm{N}$ response of three maize hibrids. Crop Sci., 24: 277-281.

TSAI, C.Y.; D.M. HUBER, H.L. WARREN; 1980. A proposed role of sein and glutelin as $\mathrm{N}$ sinks in maize. Plant Physiol. $\underline{66}: 330-333$.

TSAI, C.Y.; H.L. WARREN; D.M. HUBER e R.A. BRESSAN, 1983. In teractions between the kernel $\mathrm{N}$ sinks, grain yield and protein nutritional quality of maize. J. Sci. Food Agric. $34: 255-263$.

VASCONCELLOS, C.A.; J.U.A. BARBOSA; H.L. dos SANTOS e G.E • FRANÇA, 1983. Acumulação de massa seca e de nutrientes por duas cultivares de milho com e sem irrigação suple mentar. Pesq. Agropec. Brasil; 8:887-901. 
WATSON, D.J., 1952. The physiological basic of variation in yield Adv. Agron. 4: 101-145.

WEIL, R.R. e W. KROOTJE, 1979. Organic matter decomposition in a soil heavily amended with poultry manure. Journal of Enviromnental Quality, 8 (4): 582-588. 


\section{APENDICE}


Apêndice 1.Dados Meteorolögicos Diärios - Novembro/1984. Jaboti cabal - SP.

\begin{tabular}{|c|c|c|c|c|c|c|}
\hline \multirow[b]{2}{*}{ Dias } & \multicolumn{3}{|c|}{ Temperatura ${ }^{\circ} \mathrm{C}$} & \multirow{2}{*}{$\begin{array}{l}\text { UR } \\
\frac{8}{8}\end{array}$} & \multirow{2}{*}{$\begin{array}{c}\text { Precipitação } \\
(\mathrm{mm})\end{array}$} & \multirow{2}{*}{$\begin{array}{c}\text { Insol ação } \\
\text { (Horas) }\end{array}$} \\
\hline & Max. & Min. & Média & & & \\
\hline 01 & 33,6 & 19,7 & 27,2 & 51,3 & - & 9,6 \\
\hline 02 & 34,7 & 21,4 & 27,9 & 44,8 & - & 10,6 \\
\hline 03 & 35,6 & 20,9 & 28,0 & 34,0 & - & 11,2 \\
\hline 04 & 36,2 & 21,3 & 28,1 & 46,5 & - & 10,8 \\
\hline 05 & 36,2 & 20,2 & 27,4 & 53,5 & 1,4 & 7,5 \\
\hline 06 & 32,7 & 21,7 & 25,8 & 69,5 & 0,4 & 3,6 \\
\hline 07 & 34,5 & 21,5 & 28,3 & 51,0 & - & 9,5 \\
\hline 08 & 35,8 & 19,9 & 28,2 & 36,8 & - & 11,8 \\
\hline 09 & 34,3 & 20,2 & 26,2 & 48,0 & 3,5 & 6,0 \\
\hline 10 & 26,1 & 20,4 & 23,5 & 81,8 & 0,7 & 0,0 \\
\hline 11 & 33,4 & 20,8 & 25,2 & 74,5 & 35,2 & 5,8 \\
\hline 12 & 25,0 & 20,0 & 21,6 & 89,8 & 17,3 & 0,0 \\
\hline 13 & 28,7 & 19,7 & 23,2 & 80,3 & - & 5,1 \\
\hline 14 & 31,1 & 14,4 & 23,1 & 60,8 & - & 11,8 \\
\hline 15 & 31,2 & 15,9 & 23,8 & 52,8 & - & 11,4 \\
\hline 16 & 33,4 & 17,0 & 24,9 & 56,5 & 6,0 & 9,7 \\
\hline 17 & 27,2 & 16,8 & 22,0 & 82,8 & - & 1,6 \\
\hline 18 & 25,8 & 19,6 & 22,1 & 81,8 & 4,5 & 0,2 \\
\hline 19 & 30,2 & 17,3 & 23,9 & 70,5 & - & 8,4 \\
\hline 20 & 29,7 & 19,4 & 22,3 & 85,8 & 23,9 & 2,5 \\
\hline 21 & 27,5 & 18,0 & 22,2 & 74,3 & - & 8,3 \\
\hline 2.2 & 26,2 & 17,7 & 22,0 & 85,0 & 0,5 & 0,0 \\
\hline 23 & 29,7 & 19,2 & 24,0 & 74,0 & - & 8,5 \\
\hline 24 & 31,5 & 19,8 & 23,8 & 72,5 & 27,0 & 7,4 \\
\hline 25 & 27,0 & 20,0 & 23,4 & 86,8 & 50,0 & 5,6 \\
\hline 26 & 28,6 & 20,0 & 22,3 & 84,0 & 23,7 & 4,0 \\
\hline 27 & 27,5 & 18,2 & 21,7 & 87,0 & 8,9 & 4.4 \\
\hline 28 & 29,8 & 16,3 & 23,1 & 64,3 & - & 12,0 \\
\hline 29 & 31,1 & 17,7 & 23,7 & 70,8 & - & 11,9 \\
\hline 30 & 30,0 & 17,6 & 24,5 & 72,8 & - & 10,2 \\
\hline Média & 30,8 & 19,1 & 24,4 & 67,5 & - & - \\
\hline TOTAL & & & & & 202,9 & 209,4 \\
\hline
\end{tabular}


Apêndice 2.Dados Meteorológicos Diārios - Dezembro/1984. Jabo ticabal - SP.

\begin{tabular}{|c|c|c|c|c|c|c|}
\hline \multicolumn{4}{|c|}{ Temperatura ${ }^{\circ} \mathrm{C}$} & \multirow{2}{*}{$\begin{array}{l}\text { UR } \\
8 \\
\end{array}$} & \multirow{2}{*}{$\begin{array}{c}\text { Precipitação } \\
(\mathrm{mm})\end{array}$} & \multirow{2}{*}{$\begin{array}{l}\text { Insolação } \\
\text { (Horas) }\end{array}$} \\
\hline Dia & Max. & Min. & Média & & & \\
\hline 01 & 30,0 & 19,8 & 24,5 & 80,5 & 27,0 & 4,7 \\
\hline 02 & 26,2 & 19,2 & 21,7 & 91,2 & 3,4 & 2,7 \\
\hline 03 & 30,1 & 18,6 & 24,7 & 76,5 & - & 9,3 \\
\hline 04 & 30,3 & 19,5 & 24,3 & 80,7 & 0,5 & 6,9 \\
\hline 05. & 29,2 & 20,2 & 23,6 & 83,7 & 1,0 & $.5,8$ \\
\hline 06 & 26,0 & 18,8 & 23,0 & 80,0 & - & 1,8 \\
\hline 07 & 27,2 & 20,3 & 22,7 & 92,5 & 14,2 & 0,0 \\
\hline 08 & 26,3 & 19,6 & 22,1 & 88,5 & 5,4 & 0,3 \\
\hline 09 & 29,0 & 17,8 & 23,1 & 80,2 & - & 5,2 \\
\hline 10 & 31,8 & 18,2 & 25,2 & 78,7 & - & 8,0 \\
\hline 11. & 31,8 & 18,0 & 25,6 & 71,5 & 9,2 & 9,1 \\
\hline 12 & 26,5 & 17,6 & 23,1 & 84,2 & 3,7 & 0,1 \\
\hline 13 & 26,6 & 21,0 & 22,5 & 94,5 & 26,3 & 1,7 \\
\hline 14 & 27,0 & 20,0 & 22,5 & 88,7 & 24,4 & 0,3 \\
\hline 1.5 & 28,2 & 20,2 & 22,2 & 89,7 & 0,7 & 0,3 \\
\hline 16 & 30,9 & 18,4 & 23,6 & 82,7 & 0,5 & 8,6 \\
\hline 17 & 29,5 & 20,3 & 23,0 & 84,2 & 1,5 & 3,7 \\
\hline 18 & 29,6 & 20,0 & 23,9 & 71,5 & - & 8,9 \\
\hline 19 & 29,6 & 17,9 & 22,7 & 69,2 & - & 11,2 \\
\hline 20 & 30,5 & 16,8 & 23,6 & 61,2 & - & 11,9 \\
\hline 21 & 31,8 & 18,1 & 24,6 & 59,0 & - & 11,9 \\
\hline 22 & 30,2 & 20,5 & 24,3 & 56,5 & - & 11,6 \\
\hline 23 & 31,7 & 16,0 & 24,0 & 57,7 & - & 11,3 \\
\hline 24 & 32,6 & 15,4 & 25,5 & 58,7 & - & 10,1 \\
\hline 25 & 30,5 & 20,7 & 24,1 & 74,0 & 0,3 & 3,5 \\
\hline 26 & 30,6 & 20,5 & 24,2 & 79,7 & 35,7 & 8,1 \\
\hline 27 & 29,8 & 19,2 & 24,3 & 79,2 & 0,5 & 5,5 \\
\hline 28 & 27,8 & 19,1 & 22,9 & 85,2 & - & 1,6 \\
\hline 29 & 28,0 & 20,0 & 23,6 & 83,7 & 25,0 & 2,9 \\
\hline 30 & 27,0 & 20,0 & 22,4 & 92,0 & 5,3 & 0,0 \\
\hline 31 & 26,0 & 18,0 & 22,8 & 86,7 & - & 2,2 \\
\hline Média & 29,1 & 19,0 & 23,5 & 78,8 & - & - \\
\hline TOTAL & & & & & 184,6 & 169,2 \\
\hline
\end{tabular}


Apêndice 3. Dados Meteorológicos Diārios - Janeiro/1985. Jabotí cabal - SP.

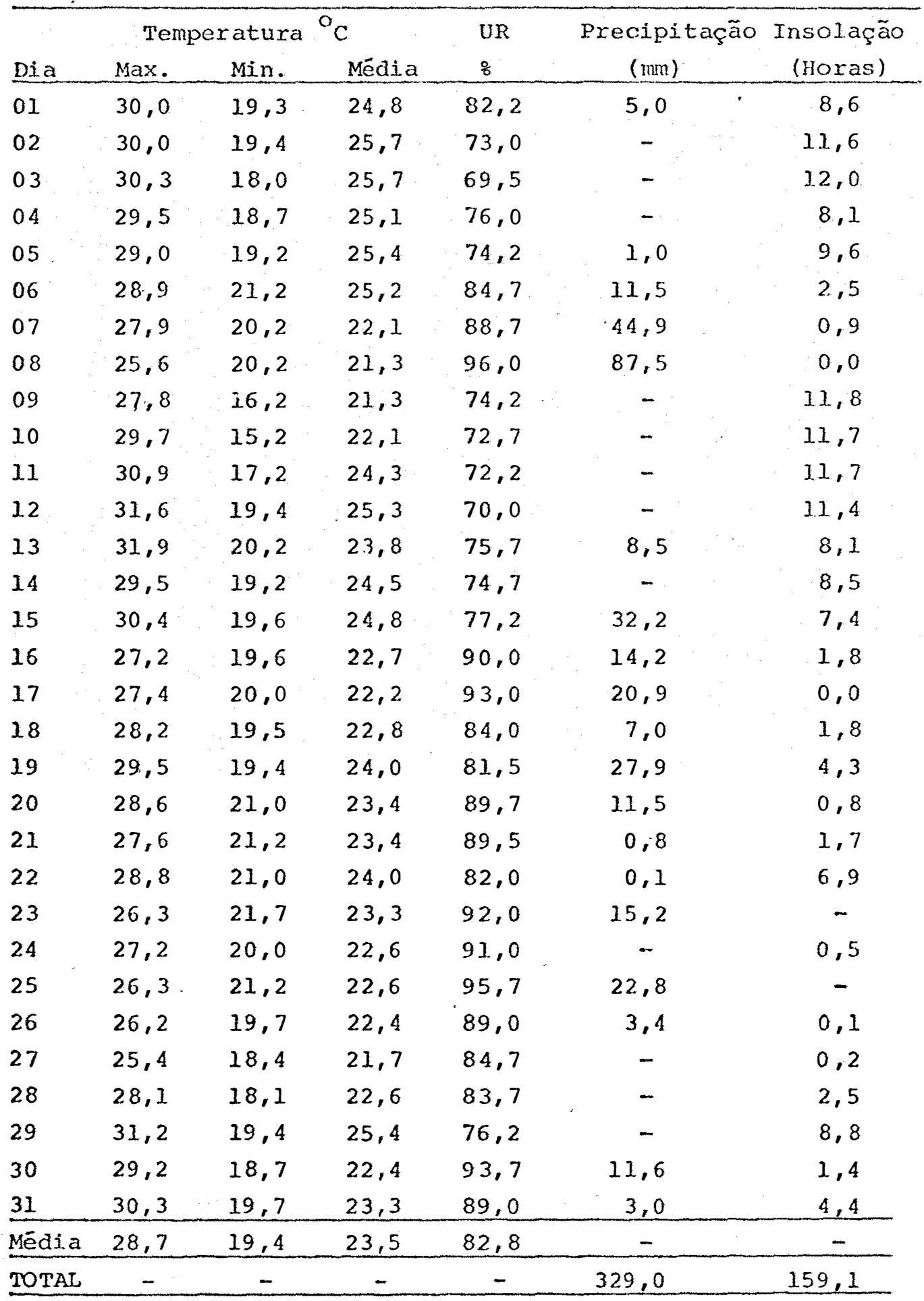


Apênidice 4.Dados Meteorológicos Diários - Fevereiro/1985. Jabo ticabal - SP.

\begin{tabular}{|c|c|c|c|c|c|c|}
\hline \multirow[b]{2}{*}{ Dia } & \multicolumn{3}{|c|}{ Temperatura ${ }^{\circ} \mathrm{C}$} & \multirow{2}{*}{$\begin{array}{l}\text { UR } \\
q\end{array}$} & \multirow{2}{*}{$\begin{array}{c}\text { Precipitaçäo } \\
\text { (mm) }\end{array}$} & \multirow{2}{*}{$\begin{array}{l}\text { Insolação } \\
\text { (Hoxas) }\end{array}$} \\
\hline & $\operatorname{Max}$ & Min. & Média & & & \\
\hline 01 & $30 ; 0$ & 20,3 & 23,3 & 88,2 & 5,3 & 5,8 \\
\hline 02 & 31,7 & 19,7 & 25,6 & 79,7 & 11,6 & 9,4 \\
\hline 03 & 32,2 & 19,7 & 25,7 & 72,7 & - & 11,0 \\
\hline 04 & 33,1 & 19,8 & 25,6 & 72,2 & - & 9,7 \\
\hline 05 & 31,6 & 19,2 & 24,3 & 79,2 & 9,1 & 8,1 \\
\hline 06 & 32,7 & 19,8 & 25,2 & 72,7 & - & 10,4 \\
\hline 07 & 32,5 & 20,3 & 25,1 & 77,2 & - & 9,3 \\
\hline 08 & 31,9 & 20,2 & 24,8 & 77,7 & 87,8 & 7,1 \\
\hline 09 & 31,2 & 18,9 & 24,7 & 79,5 & - & 8,9 \\
\hline 10 & 29,3 & 18,7 & 24,4 & 86,0 & 2,7 & 5,7 \\
\hline 11 & 30,9 & 20,5 & 24,5 & 84,2 & 0,3 & 3,5 \\
\hline 12 & 31,4 & 20,7 & 24,3 & 83,7 & 6,8 & 5,4 \\
\hline 13 & 32,9 & 20,2 & 25,7 & 79,5 & 7,3 & 8,7 \\
\hline 14 & 31,9 & 19,7 & 25,0 & 76,0 & - & 7,4 \\
\hline 15 & 33,5 & 19,8 & 26,0 & 74,2 & 7,7 & 10,5 \\
\hline 16 & 32,8 & 21,0 & 26,0 & 77,2 & 0,2 & 6,8 \\
\hline 27 & 32,8 & 20,9 & 25,4 & 72,0 & - & 10,9 \\
\hline 18 & 32,5 & 20,5 & 25,5 & 69,0 & - & 8,1 \\
\hline 19 & 32,2 & 20,7 & 26,5 & 63,2 & - & 21,6 \\
\hline 20 & 33,2 & 20,3 & 26,7 & 58,2 & - & $3.1,3$ \\
\hline 21 & 32,4 & 20,5 & 25,6 & 71,5 & 0,7 & 5,4 \\
\hline 22 & 30,5 & 20,9 & 24,3 & 84,5 & 6,2 & 8,6 \\
\hline 23 & 29,6 & 20,8 & 23,4 & 87,2 & - & 2,8 \\
\hline 24 & 28,3 & 19,3 & 22,8 & 81,2 & 1,4 & 1,0 \\
\hline 25 & 29,5 & 19,9 & 23,6 & 87,5 & 12,5 & 5,5 \\
\hline 26 & 26,2 & 20,3 & 22,6 & 91,5 & - & 1,5 \\
\hline 27 & 28,1 & 20,6 & 23,2 & 88,2 & 6,8 & 1,2 \\
\hline 28 & 28,9 & 20,2 & 22,4 & 84,7 & 71,0 & 1,7 \\
\hline Média & 31,1 & 20,1 & 24,7 & 78,3 & - & - \\
\hline TOTAL & & & & & 237,4 & 197,3 \\
\hline
\end{tabular}


Ppêndice 5. Dados Meteorológicos Diários - Março/1985. Jabotica bal - SP.

\begin{tabular}{|c|c|c|c|c|c|c|}
\hline \multirow[b]{2}{*}{ Dias } & \multicolumn{3}{|c|}{ Temperatura ${ }^{\circ} \mathrm{C}$} & \multirow{2}{*}{$\begin{array}{l}\text { UR } \\
8 \\
\end{array}$} & \multirow{2}{*}{$\begin{array}{c}\text { Precipitação } \\
(\mathrm{mm})\end{array}$} & \multirow{2}{*}{$\begin{array}{c}\begin{array}{c}\text { Insolaçãc } \\
\text { (Horas) }\end{array} \\
\end{array}$} \\
\hline & Max. & Min. & Média & & & \\
\hline 01 & 23,2 & 19,2 & 20,8 & 97,5 & 14,7 & 0,0 \\
\hline 02 & 22,7 & 19,7 & 21,2 & 96,5 & 19,0 & 0,0 \\
\hline 03 & 23,4 & 18,9 & 21,5 & 93,7 & 1,8 & 0,0 \\
\hline 04 & 26,3 & 19,0 & 20,9 & 90,5 & $1,9$. & 0,7 \\
\hline 05 & 27,2 & 19,3 & 22,5 & 91,0 & 1,5 & 1,6 \\
\hline 06 & 23,8 & 19,7 & 21,4 & 94.0 & 2,7 & 0,4 \\
\hline 07 & 28,8 & 19,8 & 23,4 & 89,2 & 2,2 & 2,5 \\
\hline 08 & 30,1 & 21,0 & 24,5 & 80,2 & 0,3 & 7,8 \\
\hline 09 & 31,3 & 20,1 & 25,1 & 79,2 & - & 10,0 \\
\hline 10 & 29,0 & 19,5 & 23,6 & 84,7 & 12,5 & 3,7 \\
\hline 11 & 29,3 & 21,2 & 24,2 & 82,2 & 6,2 & 4,4 \\
\hline 12 & 28,9 & 17,8 & 22,5 & 69,2 & - & 9,8 \\
\hline 13 & 29,8 & 15,2 & 23,1 & 63,5 & - & 9,7 \\
\hline 14 & 31,2 & 17,0 & 24,3 & 74,5 & - & 9,5 \\
\hline 15 & 29,4 & $2], 0$ & 23,7 & 85,5 & 31,7 & 3,0 \\
\hline 26 & 27,8 & 20,2 & 22,6 & 92,0 & 2,2 & 1,9 \\
\hline 17 & 29,2 & 20,8 & 23,2 & 87,2 & 24,5 & 4,9 \\
\hline 18 & 29,7 & 19,6 & 23,9 & 84,0 & - & 8,3 \\
\hline 19 & 31,2 & 18,7 & 23,9 & 77,5 & 4,8 & 9,5 \\
\hline 20 & 29,4 & 19,7 & 24,5 & 85,0 & 4,7 & 5,0 \\
\hline 21 & 31,3 & 20,0 & 24,8 & 81,0 & - & 7,6 \\
\hline 22 & 32,4 & 21,3 & 25,4 & 74.0 & 2,2 & 8,7 \\
\hline 23 & 32,0 & 20,6 & 25,8 & 72,7 & - & 9,1 \\
\hline 24 & 33,2 & 20,2 & 26,7 & 68,0 & - & 9,6 \\
\hline 25 & 34,7 & 20,1 & 26,9 & 68,0 & - & 9,7 \\
\hline 26 & 33,1 & 21,2 & 25,9 & 76,7 & - & 8,2 \\
\hline 27 & 33,0 & 20,7 & 26,6 & 73,2 & 1,1 & 9,4 \\
\hline 28 & 31,6 & 20,8 & 24,9 & 83,5 & - & 5,7 \\
\hline 29 & 32,6 & 20,5 & 25,5 & 79.7 & $\because$ & 7,4 \\
\hline 30 & 31,9 & 20,6 & 24,0 & 91,7 & 2,3 & 0,6 \\
\hline 31 & 28,7 & 20,4 & 24,0 & 83,0 & - & 5,0 \\
\hline Mëdia & 29,5 & 19,8 & 23,9 & 82,0 & $=$ & - \\
\hline TOTAL & & & & & 136,2 & 176,7 \\
\hline
\end{tabular}


Apêndice.6.Dados Meteorológicos Diārios - Abril/1985. Jabotica bal - SP.

\begin{tabular}{|c|c|c|c|c|c|c|}
\hline Dias & $\begin{array}{r}\text { Te } \\
\text { Max. }\end{array}$ & $\begin{array}{c}\text { peratur } \\
\text { Min. }\end{array}$ & ${ }^{\circ} \mathrm{C}$ & $\begin{array}{l}\text { UR } \\
\frac{0}{6} \\
\end{array}$ & $\begin{array}{c}\text { Precipitação } \\
(\mathrm{mm})\end{array}$ & $\begin{array}{c}\text { Insolação } \\
\text { (Horas) }\end{array}$ \\
\hline 01 & 31,5 & 20,5 & 25,4 & 73,2 & - & 9,3 \\
\hline 02 & 32,0 & 20,7 & 26,1 & 69,5 & 10,7 & 9,3 \\
\hline 03 & 31,9 & 20,8 & 24,4 & 77,2 & 3,9 & 8,5 \\
\hline 04 & 27,2 & 19,9 & 22,3 & 85,0 & 0,1 & 0,3 \\
\hline 05 & 30,4 & 19,2 & 22,9 & 84,0 & 2,9 & 6,7 \\
\hline 06 & 28,2 & 19,3 & 23,2 & 84,2 & - & 2,4 \\
\hline 07 & 30,7 & 19,3 & 23,8 & 81,5 & 13,2 & 8,4 \\
\hline 08 & 30,5 & 19,0 & 23,1 & 80,2 & - & 9.0 \\
\hline 09 & 31,4 & 18,3 & 22,6 & 89,5 & 22,7 & 6,1 \\
\hline 10 & 30,0 & 17,6 & 23,4 & 75,0 & - & 8,1 \\
\hline 11 & 29,2 & 20,0 & 23,6 & 80,0 & - & 4,3 \\
\hline 12 & 29,9 & 19,2 & 23,8 & 74,5 & 0,5 & 8,8 \\
\hline 13 & 29,0 & 18,8 & 22,3 & 81,7 & 15,6 & 8,9 \\
\hline 14 & 29,5 & 18,9 & 23,3 & 82,0 & - & 6,1 \\
\hline 15 & 29,8 & 19,2 & 23,6 & 79,5 & - & 8,1 \\
\hline 16 & 26,8 & 20,5 & 22,5 & 91,0 & 15,2 & 1,1 \\
\hline 17 & 26,2 & 20,7 & 21,4 & 94,0 & 12,0 & 1,0 \\
\hline 18 & 28,6 & 18,7 & 22,9 & 87,5 & - & 6,9 \\
\hline 19 & 28,6 & 19,0 & 22,0 & 78,7 & - & 9,9 \\
\hline 20 & 27,2 & 15,6 & 20,6 & 73,5 & - & 10,4 \\
\hline 21 & 26,6 & 15,2 & 20,3 & 68,7 & - & 9,6 \\
\hline 22 & 27,5 & 13,2 & 19,6 & 67,7 & - & 20,5 \\
\hline 23 & 28,4 & 13,8 & 21,2 & 69,7 & - & 9,1 \\
\hline 24 & 28,2 & 18,2 & 21,9 & 71,7 & - & 9,2 \\
\hline 25 & 28,5 & 16,6 & 21,3 & 75,7 & 1,3 & 8,9 \\
\hline 26 & 26,7 & 18,0 & 21,2 & 73,5 & 16,6 & 5,3 \\
\hline 27 & 29,4 & 17,4 & 22,2 & 68,2 & 1,1 & 8,7 \\
\hline 28 & 30,2 & 17,3 & 23,4 & 66,7 & - & 9,0 \\
\hline 29 & 30,2 & 18,2 & 24,1 & 71,7 & - & 8,8 \\
\hline 30 & 27,1 & 18,8 & 22,9 & 78,7 & 2,3 & 3,8 \\
\hline Média & 29,0 & 18,4 & 22,7 & 77,8 & - & - \\
\hline TOTAL & & & & & 118,1 & 216,5 \\
\hline
\end{tabular}


Apêndice 7. Dados Meteorológicos Diários - Maio/1985. Jabotica bal - SP.

\begin{tabular}{|c|c|c|c|c|c|c|}
\hline \multirow[b]{2}{*}{ Dias } & \multicolumn{3}{|c|}{ Temperatura ${ }^{\circ} \mathrm{C}$} & \multirow{2}{*}{$\begin{array}{l}\text { UR } \\
: \\
\end{array}$} & \multirow{2}{*}{$\begin{array}{c}\text { Precipitação } \\
(\mathrm{mm})\end{array}$} & \multirow{2}{*}{$\begin{array}{c}\text { Insolação } \\
\text { (Horas) }\end{array}$} \\
\hline & Max. & Min. & Média & & & \\
\hline 01 & 26,2 & 19,9 & 22,1 & 82,0 & - & 2.8 \\
\hline 02 & 26,6 & 16,4 & 20,5 & 82,2 & - & 8,8 \\
\hline 03 & 26,2 & 15,0 & 19,4 & 77,2 & - & 9,2 \\
\hline 04 & 26,3 & 13,9 & 17,9 & 76,7 & - & 10,2 \\
\hline 05 & 24,4 & 9,6 & 16,9 & 66,7 & - & 9,9 \\
\hline 06 & 28,6 & 9,5 . & 20,6 & 61,0 & - & 9,1 \\
\hline 07 & 28,2 & 11,8 & 21,3 & 65,0 & - & 9,2 \\
\hline 08 & 27,6 & 13,4 & 21,7 & 81,0 & - & 9,2 \\
\hline 09 & 25,4 & 14,7 & 20,8 & 77,2 & - & 0,1 \\
\hline 20 & 26,6 & 19,0 & 22,0 & 69,0 & - & 8,3 \\
\hline 11 & 26,0 & 12,2 & 19,6 & 67,7 & - & 9,1 \\
\hline 12 & 25,7 & 11,9 & 19,0 & 63,5 & - & 9,3 \\
\hline 13 & 26,3 & 11,6 & 28,1 & 68,0 & - & 8,5 \\
\hline 14 & 27,3 & 11,3 & 18,9 & 64,2 & - & 10,0 \\
\hline 15 & 27,4 & 11,3 & 18,9 & 64,2 & - & 10,0 \\
\hline 16 & 29,2 & 12,9 & 20,4 & 65,0 & - & 9,7 \\
\hline 17 & 30,0 & 13,9 & 21,7 & 63,7 & - & 9,7 \\
\hline 18 & 29,2 & 15,0 & 21,7 & 59,0 & - & 9.9 \\
\hline 19 & 29,2 & 14,8 & 21,6 & 63,2 & - & 9,8 \\
\hline 20 & 28,2 & 17.1 & 22,7 & 69,5 & - & 0,4 \\
\hline 21 & 28,6 & 18,2 & 21,0 & 78,7 & 4,9 & 5,0 \\
\hline 22 & 25,5 & 14,9 & 19,8 & 85,7 & - & 8,0 \\
\hline 23 & 28,2 & 13,7 & 20,8 & 70,2 & - & 9,5 \\
\hline 24 & 28,8 & 15,0 & 21,5 & 70,5 & - & 8,7 \\
\hline 25 & 27,5 & 15,0 & 21,1 & 63,0 & - & 9,6 \\
\hline 26 & 28,6 & 14,1 & 21,3 & 61,7 & - & 9,3 \\
\hline 27 & 27,7 & 14,0 & 20,4 & 65,5 & - & 9,3 \\
\hline 28 & 29,0 & 13,4 & 21,1 & 64,2 & - & 9,7 \\
\hline 29 & 28,2 & 13,9 & 20,3 & 65,2 & - & 9,7 \\
\hline 30 & 28,2 & 13,8 & 20,0 & 53,7 & - & 9,5 \\
\hline 31 & 26,8 & 13,6 & 20,0 & 63,0 & - & 9,6 \\
\hline Média & 27,5 & 14,0 & 20,4 & 68,6 & - & - \\
\hline TOTAL & & & & & 4,9 & 261,1 \\
\hline
\end{tabular}

